\title{
Capture Zone Analyses of Two Airlift Recirculation Wells in the Southern Sector of A/M Area (U)
}

Westinghouse Savannah River Company Savannah River Site Aiken, SC 29808

\section{UNCLASSIFIED \\ DOES NOT CONTAN UNCLASSIFIED CONTROLIE-} ADC \&

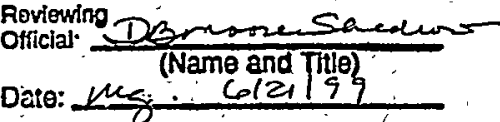

Prepared for the U. S. Department of Energy under contract nố. DE-AC09-96SR18500 
WSRC-TR-99-00203

\section{DISCLAIMER}

This report was prepared as an account of work sponsored by an agency of the United States Government. Neither the United States Government nor any agency thereof, nor any of their employees, makes any warranty, express or implied, or assumes any legal liability or responsibility for the accuracy, completeness, or usefulness of any information, apparatus, product, or process disclosed, or represents that its use would not infringe privately owned rights. Reference herein to any specific commercial product, process, or service by trade name, trademark, manufacturer, or otherwise does not necessarily constitute or imply its endorsement, recommendation, or favoring by the United States Government or any agency thereof. The views and opinions of authors expressed herein do not necessarily state or reflect those of the United States Government or any agency thereof.

This report has been reproduced directly from the best aviilable copy.

Available to DOE and DOE contractors from the Office of Scientific and Technical Information, P.O. Box 62, Oak Ridge, TN 37831; prices available from (615) 576-8401.

Available to the public from the National Technical Information Service, U.S. Department of Commerce, 5285 Port Royal Road, Springfield, VA 22161.

Prepared for the U. S. Department of Energy under contract no. DE-AC09-96SR18500 


\section{Capture Zone Analyses of Two Airlift Recirculation Wells in the Southern Sector of A/M Area}

by

S. E. Aleman

Westinghouse Savannah River Company

Savannah River Site

Aiken, South Carolina 29808

L. L. Hamm

\section{RECEIVED \\ SEP 271999 \\ OSTI}

DOE Contract No. DE-AC09-96SR18500

This paper was prepared in connection with work done under the above contract number with the U.S.

Department of Energy. By acceptance of this paper, the publisher and/or recipient acknowledges the U.S.

Government's right to retain a nonexclusive, royalty-free license in and to any copyright covering this paper, along with the right to reproduce and to authorize others to reproduce all or part of the copyrighted paper. 


\section{DISCLAIMER}

Portions of this document may be illegible in electronic image products. Images are produced from the best available original document. 
WSRC-TR-99-00203

Keywords: Capture Zone

Groundwater

Recirculation well

Retention: $\quad$ Permanent

\section{Capture Zone Analyses of Two Airlift Recirculation Wells in the Southern Sector of $\mathbf{A} / \mathbf{M}$ Area (U)}

Sebastian E. Aleman

L. Larry Hamm

Publication Date: June 1999

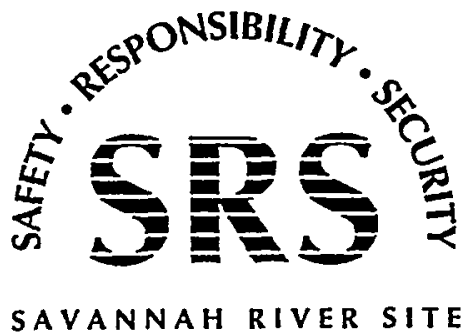

Westinghouse Savannah River Company

Savannah River Site

Aiken, SC 29808 
WSRC-TR-99-00203

DOCUMENT:

TITLE:
WSRC-TR-99-00203

Capture Zone Analyses of Two Airlift Recirculation Wells in the Southern Sector of A/M Area (U)

Authentication and Approvals:

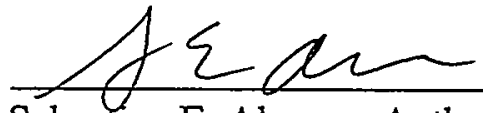

Sebastian E. Aleman, Author (ERTS/SRTC)

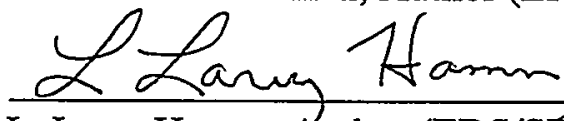

L. Larry Hamm, Author (EDS/SRTC)

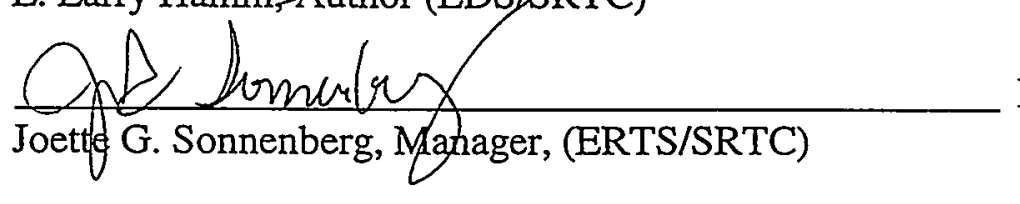

Date: $6 / 21 / 99$

Date: $6-21-99$

Date: $6-21-99$

ii 


\section{TABLE OF CONTENTS}

1.0 Executive Summary.............................................................................................................

2.0 Introduction and Background .............................................................................................. I

2.1 Prior Modeling Efforts..................................................................................................................... 2

2.2 Modeling Strategy Adopted.......................................................................................................................... 2

3.0 Groundwater Flow Model............................................................................................................... 3

3.1 Conceptual Model........................................................................................................................................... 4

3.2 Two-Dimensional Areal Grid .................................................................................................................... 5

3.3 Hydrostratigraphy................................................................................................................................... 5

3.4 Three-Dimensional Grid.................................................................................................................................... 6

3.5 Aquifer Material Properties .......................................................................................................................... 7

3.6 Flow Model Boundary Conditions........................................................................................................ 7

3.6.1 Specified Hydraulic Head Boundary Conditions ................................................................................... 8

3.6.2 ARW Well Boundary Conditions ................................................................................................................ 9

3.7 Flow Model Calibration........................................................................................................................................... 9

4.0 Mass Balance Models................................................................................................. 10

4.1 CSTR Model and Limitations .................................................................................................................. 10

4.2 Plug-Flow Model and Limitations .................................................................................................. 11

4.3 FACT-Transport Model and Limitations ....................................................................................... 12

4.4 Unmitigated TCE Plume.......................................................................................................................... 13

5.0 Flow Model Results............................................................................................................ 14

5.1 Flow Simulations ................................................................................................................................................. 14

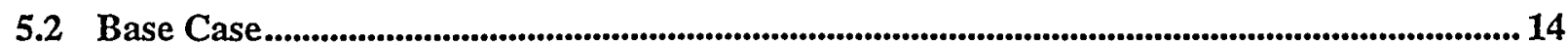

5.3 Nominal-A Case (both ARWs operating)........................................................................................ 14

5.4 Nominal-B Case (ARW SSR-011 operating only) ............................................................................ 16

5.5 Nominal-C Case (ARW SSR-012 operating only) ......................................................................... 16

5.6 Sensitivity Cases ........................................................................................................................................ 17

6.0 Mass Balance Results..................................................................................................................... 19

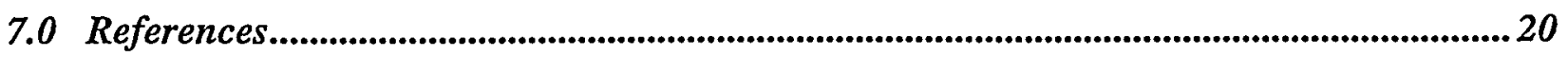


WSRC-TR-99-00203

\section{LIST OF TAEILES}

Table I Hydrostratigraphic "Picks" of the"Lost Lake" Aquifer Zone 23

Table 2. Time Average Monitoring Well Hydraulic Head Measurements 25

Table 3. Adjusted Monitoring Well Hydraulic Head Measurements used to Generate Calibration Targets and Head Boundary Conditions

Table 4. Summary of Recirculation and Special Monitoring Well Coordinates _ 30

Table 5. Summary of Pumping Well Tests in AM Southern Sector _ 30

Table 6. List of Observation Wells___ 31

Table 7. Nomenclature and Parameter Settings for the Flow Simulations ___ 31

Table 8. Summary of Key Flow Results for Nominal and Sensitivity Runs _ 32 
WSRC-TR-99-00203

\section{LIST OF FIGURES}

Figure 1. Plan View of the Basemap for Southern Sector in the A/M Area 34

Figure 2.

Plan View of the Basemap Highlighting Locations of Pumping Well Tests

Figure 3.

Layout of Areal Grid for the FACT Flow and Transport Model

Figure 4.

Figure 5.

A Vertical Grid Slice (a x-plane) Through the Center of the Model Domain

37

Three-Dimensional Mesh and Material Zone

Hydrostratigraphic Nomenclature of the Southeaster Coastal Plain for the A/M Area___ 39

Figure 6.

Figure 7.

Hydrostratigraphic "Picks" of the Lost Lake Aquifer Zone

40

Figure 8.

Altitude Contour Map of the Top of the "Lost Lake" Aquifer Zone

Figure 9.

Figure 10. Altitude Contour Map of the Top of the "Upper" Interval of the Crouch Branch Confining Unit/Base of the "Lost Lake" Aquifer Zone

Figure 11. Isopach Map of the "Lost Lake" Aquifer Zone

Figure 12. Potentiometric Map of the Lost Lake Aquifer Zone

Figure 13. Computed Potentiometric Map with 5-year Timing Markers (Base Case)

Measured Hydraulic Heads for Several Monitoring Wells Near The Model Domain _ 46

Figure 14.

Figure 15.

Figure 16.

Figure 17.

Figure 18.

Figure 19.

Schematic of Basic Flow Pattern Under Vertical Recirculation Well Operation and CSTR Model _ 47

Schematic of Plug Flow Model for Vertical Recirculation Well Operation __ 48

$X Y$ Projection of Capture Zone for SSR-011 and SSR-012 (Nominal-A) _ 49

$3 D$ Streamtraces of Capture Zone for SSR-011 and SSR-012 (Nominal-A)___ 50

$3 D$ Streamtraces of Rejection Zone for SSR-011 and SSR-012 (Nominal-A)__ 51

YZ Projection of Capture Zone for SSR-011 with I-year Timing Markers (Nominal-A)___ 52

Figure 20.

YZ Projection of Rejection Zone for SSR-011 with 1-year Timing Markers (Nominal-A)

Figure 21 .

Figure 22.

Figure 23.

Figure 24.

Figure 25.

Figure 26.

Figure 27.

Figure 28.

YZ Projection of Capture Zone for SSR-012 with 1-year Timing Markers (Nominal-A)

54

YZ Projection of Capture Zone for SSR-012 with I-year Timing Markers (Nominal-A) __ 55

Contour Plot of Mid-plane Vertical Pore Velocity Field Between Wells (Nominal-A) ___ 56

Closeup of Contour Plot of Mid-plane Vertical Pore Velocity Field Between Wells (Nominal-A) — 56

Inlet TCE Plume Profile to CSTR and Plug Flow Models__ 57

TCE Concentration Back to Aquifer (Mass Balance Model Comparisons) ___ 58

TCE Extraction Mass Flowrate $(C o=3000 \mathrm{ppb}$, Nominal-A) 59

Figure 29. FACT Computed TCE Concentration Profile near SSR-011 and SSR-012 After 1 Year of ARW

Operation (Nominal-A)

60

Figure 30.

Figure 31 .

Figure 32.

Figure 33.

Figure 34.

Figure 35.

$X Y$ Projection of Capture Zone for SSR-0II (Nominal-B)

$X Y$ Projection of Capture Zone for SSR-012 (Nominal-C)

62

Vertical View of 3-D Pathlines Passing Through Monitoring Well SSM-003__ 64

Plan View of 3-D Pathlines Passing Through Monitoring Well SSM-003

64

Vertical View of 3-D Pathlines Passing Through Monitoring Well SSM-004_ 65

Plan View of 3-D Pathlines Passing Through Monitoring Well SSM-004__ 65

Figure 36. Vertical View of 3-D Pathlines Passing Through Monitoring Well SSM-007_ 66

Figure 37. Plan View of 3-D Pathlines Passing Through Monitoring Well SSM-007_ 66 


\section{TABLE OF NOTATION}

$\begin{array}{ll}\text { ARW } & \text { Airlift recirculation well. } \\ \mathrm{BE} & \text { Best estimate value. } \\ \mathrm{c} & \text { Contaminant concentration in recirculation cell, ppb. } \\ \mathrm{c}_{\mathrm{a}} & \text { Contaminant concentration in upstream aquifer capture zone, ppb. } \\ \mathrm{c}_{\infty} & \text { Ultimate cleanup contaminate concentration in downstream aquifer, ppb. } \\ \mathrm{K}_{\mathrm{h}} & \text { Horizonal hydraulic conductivity, } \mathrm{ft} / \mathrm{d} . \\ \mathrm{K}_{\mathrm{v}} & \text { Vertical hydraulic conductivity, } \mathrm{ft} / \mathrm{d} . \\ \mathrm{LB} & \text { Lower bound value. } \\ \mathrm{PCE} & \text { Perchloroethylene. } \\ \mathrm{Q}_{\mathrm{a}} & \text { Volumetric flowrate in aquifer capture zone, } \mathrm{ft}^{3} / \mathrm{d} . \\ \mathrm{Q}_{\mathrm{P} 11} & \text { Volumetric pumping rate for SSR-011, gpm. } \\ \mathrm{Q}_{\mathrm{P} 12} & \text { Volumetric pumping rate for SSR-012, gpm. } \\ \mathrm{Q}_{\mathrm{R}} & \text { Volumetric flowrate in recirculation cell, } \mathrm{ft}^{3} / \mathrm{d} . \\ \mathrm{Q}_{\mathrm{w}} & \text { Volumetric flowrate through } \mathrm{ARWs}, \mathrm{ft}^{3} / \mathrm{d} . \\ \mathrm{R} & \text { Anisotropy ratio, } \mathrm{K}_{\mathrm{h}} / \mathrm{K}_{\mathrm{v}} . \\ \mathrm{t} & \text { Time, days. } \\ \mathrm{TCE} & \text { Trichloroethylene. } \\ \mathrm{UB} & \text { Upper bound value. } \\ \mathrm{V}_{\mathrm{R}} & \text { Volume of recirculation cell, } \mathrm{ft}^{3} . \\ \mathrm{Greek} & \\ \eta & \text { Single pass extraction efficiency factor. } \\ \phi & \text { "Effective" porosity. }\end{array}$




\subsection{Executive Summary}

This report documents a series of capture zone analyses performed to assess the expected overall performance of two (of the twelve) vertical airlift recirculation wells (ARWs) (specifically, SSR011 and SSR-012) located in the Southern Sector of A/M Area. The initial placement of these ARWs was based on establishing hydraulic control over the southern migration of volatile organic compound (VOC) contaminant plumes consisting primarily of dissolved trichloroethylene (TCE) and perchloroethylene (PCE).

Simple mass balance calculations, supported by one detailed TCE FACT transport simulation, have also been performed to estimate the cleanup timing and efficiency of these ARWs given the hydrogeologic settings that they are contained within.

Several key assessments can be made based on the various analyses performed:

- Under nominal operating conditions (i.e., both ARWs pumping at $43 \mathrm{gpm}$ ) the width of the overall capture zone is predicted to be $\sim 684 \mathrm{ft}$. The distance between each ARW is $\sim 255 \mathrm{ft}$. Since an individual operating ARW at $43 \mathrm{gpm}$ has an approximately 450 to $480 \mathrm{ft}$ capture width, significant overlap occurs when both ARWs are in nominal operation.

- The degree of overlap results in a significant increase in recycling within the "composite" recirculation cell surrounding the two ARWs. Recycling during individual ARW operation is $\sim 50 \%$, while during combined ARW operations recycling approaches $\sim 80 \%$.

- Simple mass balance modeling approaches using a Plug-Flow model approximation provides basic insight into the time frame and level of cleanup achievable; whereas, the use of a CSTR modeling approach is shown to be overly conservative. These observations are based on comparisons made to a more detailed 3-D FACT transport simulation.

- TCE mass extraction rates on the order of 1 to $2 \mathrm{lbm} /$ day are predicted over the first couple of years of ARW operation. The predicted ultimate (i.e., long time) cleanup percentages under nominal conditions are $\sim 90 \%$ when a $70 \%$ single-pass vapor-phase extraction efficiency is assumed.

\subsection{Introduction and Background}

Groundwater flow modeling of vertical recirculation wells can be performed analytically under certain limiting conditions and useful parametric curves cạn be generated for certain numerical solutions. Classical results addressing vertical recirculation flows can be found in the literature (Herrling et al., 1990) Application of the classical solutions to the design of a vertical recirculation well system for the A/M Area Southern Sector was performed in (Jackson, D. G., Jr. and Looney, B. B., 1996). These idealized solutions typically assume the aquifer to be subject to: (1) a uniform one-dimensional head gradient field upstream and downstream, (2) a uniform and planar confining unit, (3) a homogeneous isotopic aquifer, and (4) well networks being 
perpendicular to natural groundwater flow. These approaches provide relatively quick and typically adequate accuracy in determining the lateral width of capture zones for simple well networks.

To assess earlier calculations, to eliminate many of the limiting assumptions mentioned above, and to incorporate new hydrogeological data, a 3-D flow model of two of the proposed twelve ARWs (i.e., SSR011 and SSR012) is developed using the FACT flow and contaminant transport code (Hamm et al., 1999).

Simple mass balance calculations are also performed to assess the performance of the ARWs over extended periods of time. These mass balance calculations are based on several simplifying assumptions which limit their applicability but should provide basic insight into the time frame and level of cleanup achievable. Results from an infinitely mixed model, a plug flow model, and a FACT transport based model are compared. The simplified plug flow modeling approach appears to provide reasonable results when compared to the more detailed and complicated 3-D transport results from FACT. Under the idealized assumptions employed ultimate cleanup efficiencies on the order of 80 to $90 \%$ are acheivable within 3 to 5 years of operation.

\subsection{Prior Modeling Efforts}

As mentioned above, classical solutions to the design of a vertical recirculation well system (i.e., a eight ARW system network pumping at $20 \mathrm{gpm}$ per well) for the A/M Area Southern Sector was performed in (Jackson, D. G., Jr. and Looney, B. B., 1996). The initial placement of these ARWs was based on establishing hydraulic control over the southern migration of volatile organic compound (VOC) contaminate plumes consisting primarily of dissolved trichloroethylene (TCE) and perchloroethylene (PCE). The twelve ARWs were placed approximately $255 \mathrm{ft}$ apart along a diagonal just downstream of the TCE $500 \mathrm{ppb}$ isocontour. The $500 \mathrm{ppb}$ contour was based on an EarthVisson ${ }^{\mathrm{TM}}$ 3-D spline fit of available data within the 1994 time frame. Since that time additional monitoring wells, as well as the placement of the twelve ARWs, have been developed and many have been in intermitent operation. More recent data on the operation of SSR-012 and for several surrounding SSM monitoring wells is documented in (White, R. M., 1999). This reference also contains mass balance calculations based on the CSTR modeling approach.

\subsection{Modeling Strategy Adopted}

Even though, a detailed 3-D flow model based on the FACT code was used by (Jackson, D. G., Jr. and Looney, B. B., 1996), the model domain covered the entire A/M Area and had multiple aquifer/aquitard units. Using the FACT predicted regional flows, the actual capture zone analyses were based on the semi-analytic methods of (Herrling et al., 1990).

To improve on this earlier modeling attempt, a new FACT based model focusing in on just the vicinity surrounding the two ARWs was chosen. With a much smaller domain (i.e., one aquifer unit with limited areal extent), significant mesh refinement needs near each ARW and its screens 
can be accomodated. This approach eliminates the need to supperimpose vertical recirculation well solutions on the FACT solutions.

The use of a characteristically flat model domain for ARW simulations was abandoned due to the difficulties assoicated with alignment of the multiple wells and varying screens heights relative to aquifer top and bottom surfaces. Therefore, this new FACT-Flow model also conforms to the most recent hydrostratigraphic picks. However, due to time constraints no attempt to account for local scale material heterogeneity was made. However, heterogeneity on the principle axis level was taken into account.

Seasonal variations in the subsurface flow field were not modeled. Instead, a time averaged steady-state flow model was developed. Calibration of this steady-state FACT-Flow model was based on comparison to available potentiometric hydraulic head data tmed averaged over the period of 1990 through 1999.

The actual capture zone analyses consist of integrating the predicted 3-D steady-state pore velocity vector field over time, starting at various specified seed locations. Both forward and reverse tracking was performed. These particle tracking calculations were interactively performed within the commerically available graphical package TecPlot ${ }^{\mathrm{TM}}$. Typically, seed values (i.e., starting points) are placed either on the intake or exhaust screens of each well and then reverse or forward particle tracking is performed, respectively. Optionally, markers are placed along each pathline to indicate transport travel times of groundwater.

Using the same FACT based grid and flow solutions described above, a 3-D detailed FACTTransport was developed for benchmarking/comparing to two simpler mass balance modeling approaches. A CSTR model and a Plug-Flow model was developed to perform simple mass balance calculations. Uncertainties within the mass balance predictions are address through a series of sensitivity runs. The sensitivity runs represent a star-pattern approach about the Nominal-A case.

\subsection{Groundwater Flow Model}

The Flow and Contaminant Transport (FACT) code (Hamm et al., 1999) was used to simulate groundwater flow at the Southern Sector of A/M Area in the vicinity of the Airlift Recirculation Wells, SSR-011 and SSR-012. FACT is a three-dimensional, finite element code designed to simulate steady-state and transient isothermal groundwater flow, moisture movement, and solute transport in variably saturated and fully saturated subsurface porous media. The new GaussLegendre elemental quadrature option in FACT was used to compute the hydraulic head field and nodal pore velocity field correctly for vertical mesh distortion within the flow domain. A series of fully saturated (confined aquifer) groundwater flow simulations were performed (Table 7) by varying the pumping rates of the ARWs, horizontal hydraulic conductivity, vertical hydraulic conductivity and porosity. The results of these flow simulations were used to perform capture zone analyses of the ARW's and to quantify the effectiveness of the ARW's using mass balance models. 
The FACT areal mesh is a $3000 \mathrm{ft}$ by $3000 \mathrm{ft}$ footprint centered about the centroid of SSR-011 and SSR-012 at (50111E, 98972.3N) in the Southern Sector of A/M Area. The mesh is refined areally near each of the ARW with a telescoping coarser mesh away from each well toward the boundaries of the domain (Figure 3). The potentiometric map of the "Lost Lake" aquifer zone (Figure 11) in the vacinity of the ARWs suggests an areal mesh alignment along the SRS coordinate system. Therefore the model coordinate system is aligned with the SRS plant grid.

The three-dimensional mesh contains a total of 318,291 nodes and 304,200 z-distorted brick elements. The number of nodes in the $\mathrm{x}, \mathrm{y}$ and $\mathrm{z}$ directions are 79,79 and 51 , respectively. The vertical extent of the mesh discretizes the "Lost Lake" aquifer zone with 51 equally spaced mesh points between the top and base of the LLAZ. The approximate mesh spacing in the vertical direction is 1 foot.

As illustrated in Figure 7, the top face of the model conforms to the top of the "Lost Lake" aquifer zone and the bottom face conforms to the "upper" interval of the Crouch Branch confining unit.

Spatially varying, time averaged hydraulic head boundary conditions were applied to the East, West, North and South faces of the flow model. The hydraulic head boundary conditions were interpolated from the potentiometric map of the LLAZ and assumed not to vary with the depth of the aquifer.

The top and bottom of the flow model are no-flow boundaries since the "green clay" confining zone and the Crouch Branch confining unit are fully competent aquitards in this study area of the Southern Sector.

\subsection{Conceptual Model}

The SSR-011 and SSR-012 ARWs are located in the Southern Sector of A/M Area. The lower (extraction) screen and upper (injection) screen are situated within the "Lost Lake" aquifer zone (LLAZ). A closeup plan view of the basemap for the Southern Sector of A/M Area is shown in Figure 1. It is believed that the "green clay" confining zone that separates the "Lost Lake" aquifer zone from the "M Area" aquifer zone (i.e., water table) is competent throughout much of the Southern Sector and begins to breakup in the northern region of the Southern Sector and further north. The strong downward head gradients observed between many of the $C$ and $B$ wells in the northern regions indicate strong recharge within those areas. For example head differences on the order of 20 feet are measured in well clusters MSB 19B/C and MSB 87B/C. In the vicinity of our proposed model domain (as outlined in Figure 1), head differences are negligible for well clusters MSB 36B/C, MSB 40B/C, MSB 74B/C, and MSB 75B/C. This suggests that this section of the "Lost Lake" aquifer zone within the Southern Sector behaves as a confined aquifer. However, in the eastern part of the Southern Sector small head differences on the order of three feet are seen in well clusters MSB 33B/C and MSB 88B/C for example. The above head differences were computed using the median head values (taken from the GIMS data set over the time period of 1/1990 to 6/1999) for each of the specified wells taken from Table 2. 


\subsection{Two-Dimensional Areal Grid}

Since the flow model is used to assess the hydraulic performance of both ARWs operating either together or in isolation, the footprint of the finite element grid was centered on the centroidal coordinates of the SSR-011 and SSR-012 ARWs. To ensure that ARW operation would not have an appreciable impact on model boundaries (i.e., its North, East, South, and West faces) the areal grid was extented out $+/-1500$ feet in both directions from the ARW centroid. This areal extent also placed the four vertical faces near existing monitoring wells within the region providing improved head boundary conditions specification. The areal extent of the flow model grid in comparison to neighboring monitoring wells and basemap features is provided in Figure 1. Those well D's whose monitoring screens are within the "Lost Lake" aquifer zone are also provided. The planned twelve ARWs (i.e. SSR-001 through SSR-012) are also shown as a series of open circles following a diagonal line. Well coordinates and screen heights are provided in Table 4 for the two SSRs being studied and several neighboring special monitoring wells.

No specific orientation could be found that would result in no-flow boundary conditions along any of the vertical faces. A slight rotational improvement approaching no-flow faces could be achieved (i.e., overall flow paths are south to south-west) at the cost of increased complexity in addressing coordinate transformation of results and data sets. For simplicity, the areal grid was oriented with respect to site coordinates.

Vertical recirculation wells produce strong vertical velocity fields in the near field. As such, the mesh demands near the two ARW's require significant refinement. To accommodate the ARWs mesh demands, our grid was telescoped out from each of the two ARWs while limiting the amplification factor to less than two. The FACT flow model grid shown in a plan view is presented in Figure 3. ARWs SSR-001 and SSR-012 are located at the lower-left and upper-right cross-hatches, respectively. The number of grid points in each direction are $\mathrm{n}_{\mathrm{x}}=\mathrm{n}_{\mathrm{y}}=79$ (a total of 6241 nodes per vertical plane).

\subsection{Hydrostratigraphy}

The SRS is underlain by Atlantic Coastal Plain sediments that dip and thicken to the southeast. Lithostratigraphically, these sediments range from Late Cretaceous to Recent in age and comprise layers of sand, muddy sand, and mud with subordinate calcareous sediments. The A/M Area lies within the up-dip area of the coastal plain deposits, approximately 20 miles from the Fall Line (Figure 1-1, Smits et al., 1999).

The hydrostratigraphic nomenclature currently established for the SRS region and A/M Area by Aadland and others (1995a, 1995b) is adopted in this report (Figure 6). The A/M Area lies within the up-dip part of the Floridian-Midville aquifer system as defined by Aadland and others (1995b). Distinct hydrostratigraphic units of the Floridian-Midville aquifer system are delineated as informal aquifer and confining zones (Aadland et al., 1995b).

The hydrostratigraphy of $\mathrm{A} / \mathrm{M}$ Area includes three aquifers of the Floridian-Midville aquifer system. The Floridian-Midville aquifer system includes the McQueen Branch aquifer, the 
Crouch Branch aquifer, and the Steed Pond aquifer. The Steed Pond Aquifer (SPA) is composed primarily of sand and clayey sands interbeds (Aadland et al., 1995b). The SPA is divided into the "M Area" aquifer zone, "green clay" confining zone and "Lost Lake" aquifer zone (LLAZ). The "Lost Lake" aquifer zone consists of yellow, tan, orange and brown, loose to slightly indurated, fine to coarse, moderately to well-sorted, occasionally pebbly sand and minor clayey sand (Smits et al., 1999). Hydrostratigraphically, the portion of the LLAZ that resides in the Southern Sector of A/M Area is the focus of this study.

Hydrostratigraphic "picks" of the top of the "Lost Lake" aquifer zone and the "upper" interval of the Crouch Branch confining unit (Base of the LLAZ) were determined from cores drilled in the A/M Area (Figure 7). The "picked" tops of the LLAZ and "upper" interval of the CBCU are tabulated in Table 1 from Smits et al. (1999) and supplemented with "picks" from cores drilled during the installation of SSR-001 through SSR-012 (White, 1998).

The base of the LLAZ is defined by the top of the "upper" interval of the CBCU (Figure 9). The top of the LLAZ is depicted in Figure 8, and the thickness is illustrated in Figure 10. The measured elevations of the top of this interval vary from 181 to $211 \mathrm{ft} \mathrm{msl}$ and the measured thickness varies from 29 to 86 feet (Smits et al., 1999).

The scattered dataset of hydrostratigraphic "picks" of the top and base of the LLAZ were each processed by the EarthVision ${ }^{\circledR}$ (Dynamic Graphics Inc., 1997) 2-D minimum tension gridding program, ev2grid, producing a two-dimensional grid of the horizon. The EarthVision ${ }^{\circledR}$ Formula Processor, evfp, was used to produce a two-dimensional grid of the LLAZ unit thickness (isopach grid) by subtracting the base grid of the LLAZ from the top grid of the LLAZ.

The top and bottom faces of the FACT flow model (top and base of LLAZ) were generated by:

- Data export of the 2-D grids of the top and base of the LLAZ to scattered datasets (evexport)

- Triangulation of the exported two-dimensional grids of the top and base of the LLAZ, respectively, and fitting with $\mathrm{c} 0$ continuous linear polynomial representations over each triangle (TriFit)

- Linear triangular interpolation for each grid at each areal location of the FACT areal mesh (TriFit)

\subsection{Three-Dimensional Grid}

Airlift recirculation wells produce strong vertical velocity fields in their vicinity. This is especially true near the ends of each well screen. To simplify the vertical meshing, a fine grid of uniformly sized elements was chosen. The number of vertical planes was set to $n_{z}=51$ (a total of 318,291 nodes and 304,200 finite elements). A vertical grid slice (i.e., a x plane) through the resulting mesh is shown in Figure 4. This $x$ plane corresponds to the center of the model domain at $x$ (East) $=50,206 \mathrm{ft}$ and index $I=40$. Also shown in Figure 4 are the screen elevations of the ARWs SSR-001 and SSR-012. 


\subsection{Aquifer Material Properties}

Within the "Lost Lake" aquifer zone clay lenses exist intermediately, which in certain locations separates the unit into "upper" and "lower "zones. The existence of such clay lenses can have major effects on the vertical flow paths and areal extent of predicted recirculation cells. However, due to the time allowed and scarcity of available information for this modeling effort, no attempt to account for such local heterogeneity is made.

On a larger scale several hydraulic pumping tests have been performed and analyzed in earlier reports. Making use of the analytical solutions for transient radial flow towards a pumping well within a confined aquifer (e.g., Hantush or Neuman solutions), hydraulic conductivities were estimated from field data for several locations within the vicinity of our model domain (see Hiergesell, R.A., 1993; Hiergesell, R.A. and Pemberton, B. E., 1995; and White, R. M., 1999). Table 5 contains a brief summary of the results provided in these references that is pertinent to this modeling effort. The location of these "Lost Lake" aquifer zone pumping tests is shown in relation to our model domain in Figure 2. The large variability in horizontal conductivity values illustrates the large scale heterogeneities present (factor of six), while the test at SSR-012 demonstrates a strong anisotopic condition with a anisotopic ratio of $\sim 18$.

Based on calibration efforts to be discussed in a later section, adequate head predictions can be achieved by assuming a homogeneous anisotopic aquifer where the best estimate (BE) values of conductivity values chosen are:

- $\mathrm{K}_{\mathrm{H}}=25.8 \mathrm{ft} / \mathrm{d}$ and $\mathrm{K}_{\mathrm{V}}=1.43 \mathrm{ft} / \mathrm{d}$

Based on the range of conductivities estimated within the various pumping tests, lower bound (LB) and upper bound (UB) values for sensitivity studies were set to:

- $\mathrm{K}_{\mathrm{H}}=21.0 \mathrm{ft} / \mathrm{d}$ and $\mathrm{K}_{\mathrm{V}}=0.715 \mathrm{ft} / \mathrm{d}$

- $\mathrm{K}_{\mathrm{H}}=57.6 \mathrm{ft} / \mathrm{d}$ and $\mathrm{K}_{\mathrm{V}}=2.145 \mathrm{ft} / \mathrm{d}$

Values for the effective porosity were taken from Table 1 of (White, R. M., 1999) and are:

- $\phi=0.20 \quad(\mathrm{BE})$

- $\phi=0.15 \quad(\mathrm{LB})$

- $\phi=0.25 \quad$ (UB)

\subsection{Flow Model Boundary Conditions}

Since only steady-state flow modeling is being performed initial conditions are only needed as an initial guess for the iterative linear algebra solver. No-flow boundaries exist on the Top and Bottom faces of the model domain. Specified hydraulic heads along the four vertical faces of the model domain must be specified. In addition, under pumping scenario cases line sources (for the 
exhausts) and line sinks (for the intakes) must also be specified. These type of boundary conditions are discussed below.

\subsubsection{Specified Hydraulic Head Boundary Conditions}

Within the region surrounding our model domain, hydraulic head measurements, well coordinates, and screen heights were extracted from the GIMS data set for the time period $1 / 1 / 1996$ to $6 / 1 / 1999$. The data set obtained was then reduced to those wells whose screen heights reside within the "Lost Lake" aquifer zone. This determination was made based on the use of the 2-D minimum tension gridding of the hydrostratigraphic surfaces. A well was defined as being within the "Lost Lake" aquifer zone if the center of its screen fell within these two confining surfaces.

Since a steady-state flow analysis is being performed, a time averaged head field is required for establishing head boundary conditions on the North, East, South, and West faces of the flow model. It is anticipated that these ARWs will be operated for several years. As such, to minimize seasonal variations the time averaging of the well data was performed over the entire time period mentioned above.

In some cases individual outliners were observed within the data set. By sorting a well's temporal data and choosing the median head value, outliers are automatically handled since there position in the sorted array is at the extreme ends. Spot checking of the median values to the time history data was performed. Time histories for several of the wells in the near vicinity of our model domain is presented in Figure 13. For example one outlier exists for the well MSB 19B. The time averaged head values (i.e., median values) for the entire data set are tabulated in Table 2.

Many of the wells located in the southern most end of the Northern Sector (e.g., MSB 3B and its neighbors) exhibited large swings in head and large vertical gradients across $\mathrm{B}$ and $\mathrm{C}$ screens. These effects result from the breaking up of the "green clay" confining zone and the existence of production wells in that vicinity. In order to establish an adequate 2-D fitting of this data set, adjustments were made based on the following:

- For well clusters where the B and C screen head values were close, their two values were arithmetically averaged;

- For well clusters where significant differences existed, the more reasonable of the two values was chosen;

- For wells located in areas where production wells may have been operating, the data point was omitted;

- For neighboring wells where significant head differences were observed, the more reasonable of the two was chosen. 
The above filtering process ultimately had the impact of shifting the predicted flow path from a south-west direction to a more south to south-west direction. The reduced ("adjusted") data set used in the fitting process is tabulated in Table 3.

EarthVision ${ }^{T M}$ fitting of the head data contained in Table 3 was performed. A 2-D potentiometric head map was computed using the 2-D minimum tension algorithm and the results are shown in Figure 11.

The data based potentiometric map shown in Figure 11 was used for supplying head BC's to the four vertical faces of the FACT flow model. Since the conceptual model assumes a confining aquifer, no vertical variation in head exists along each of the four faces. Given the extent of the model domain, the vertical head variations created by the operation of the vertical recirculation wells will not be felt at the model boundaries. Therefore, these become fixed head BC's that are unaltered during any of the subsequent analysis simulations.

\subsubsection{ARW Well Boundary Conditions}

The Airlift Recirculation Well is modeled using the well boundary condition option in FACT. The well boundary condition applies a uniform strength over the entire active portion of the well's screen (the active portion of the screen does not include any screen sections above the water table in the vadose zone) and then internally computes the appropriate volumetric flowrates to the nodes within the elements that contain the well. Note: For the quick transport model of the ARW's, the ARW is modeled using modified specified mass flow node boundary conditions. This is necessary since an injection of solute requires specification of the solute mass flowrate into the forcing vector or right-hand side (RHS) of the transport equation for each injection node of the upper well screen.

\subsection{Flow Model Calibration}

In principle, for calibration purposes the wells located within our model domain can be used to assess and adjusted the predicted head field. These potential head targets are listed in Table 6. However, wells series MSB 36 and MSB 75 reside very close to the faces of the model domain and do not provide much benefit for calibrating. On the other hand, the well series MSB 74 is located near the center of the model domain and should provide us a useful calibration target.

The flow model enforces no vertical flows at the Top and Bottom faces of the model domain (i.e., a confined aquifer), while the four remaining vertical faces (i.e., North, East, South, and West faces) have specified head conditions. Under these boundary conditions, head predictions of well targets internal to the domain (i.e., MSB 74B and MSB 74C) are not particularly sensitive to uniform $\mathrm{K}_{\mathrm{H}}$ variations. During the calibration phase several sensitivity runs were made, by varying the magnitude of $\mathrm{K}_{\mathrm{H}}$ by a factor $+/-20 \%$. Negligible changes in predicted heads were observed. To adjust the predicted head field internal to the model domain, a non-uniform conductivity field would be required. However, as shown in Table 6 for the base case, adequate FACT predictions of the internal well head targets were achieved when using a uniform $\mathrm{K}_{\mathrm{H}}$ field. 
Variations in the magnitude of this uniform $\mathrm{K}_{\mathrm{H}}$ field directly effect (similar to variations in "effective" porosity) pore velocities which control contaminant transport times.

\subsection{Mass Balance Models}

Performing transient contaminant transport modeling with source terms of the TCE plume is beyond the scope of this work. However, a natural and quick extension to the FACT flow model would be to include transport modeling on the flow solutions/grid presented in this report where an initially uniform TCE concentration is assumed without source terms. Results from such an attempt are presented in this report. It is recommended that in future efforts quantification of the initial plume profile, quantification of the upstream plume profile, and possible upstream source terms be included into the FACT transport simulations.

To address the question of how effective the operation of the ARWs will be, mass balance calculations are performed. Several simplifying assumptions are made in performing these mass balance calculations which limit their applicability but should provid basic insight into the time frame and level of cleanup achievable. Three different modeling approaches were considered:

- A "CSTR Model" was considered largely due to the fact that previous efforts (e.g., ) used such an approach. However, given the assumptions required to approximate the recirculation cell as a continuous stirred tank reactor (CSTR) greatly limits its applicability.

- A "Plug-Flow Model" was considered as an alternative to the use of a simple CSTR Model. The Plug-Flow Model eliminates the main limiting assumption used in the CSTR Modeling approach and is expected to provide reasonable $1^{\text {st }}$ order approximations.

- A simplified "FACT-Transport Model" was considered where the initial TCE concentration plume was set to a uniform value of $3000 \mathrm{ppb}$ and no potential source terms were applied. No efforts were made to refine or alter the FACT-Flow model grid to optimize the transport simulations. Representative transport values for TCE movement were used.

Note that key hydraulic information (e.g., the size of the recirculation cell and volumetric flowrate of water entering the cell through the aquifer capture zone) is necessary input into the CSTR and Plug-Flow models. This input, as well as the flow field required for the FACTTransport model, is obtained from the results of the FACT-Flow model.

\subsection{CSTR Model and Limitations}

Under certain conditions the extraction process of a vertical recirculation well can be modeled as a continuous stirred tank reactor (CSTR). For the model used here the following assumptions are made:

- The contents within the recirculation cell as a hold is spatially uniform. This assumes that infinite mixing of the fluid occurs within the recirculation cell. 
- The inlet aquifer flowrate and contaminant concentration, along with the pumping rate, are held constant.

Both of the above assumptions are violated under the ARW conditions; however, it is believed that conservative estimates for cleanup rates and ultimate cleanup levels can be estimated. For example, under actual operating conditions the intakes should be seeing higher contaminant concentration levels than modeled; thereby, experience higher vapor extraction rates.

The conceptual CSTR model when applied to an ARW is shown schematically in Figure 14. Applying a contaminant species mass balance over the recirculation cell the following $1^{\text {st }}$ order linear ordinary differential equation is obtained:

$$
V_{R} \frac{d c}{d t}=\left[Q_{a} c_{a}+Q_{w} c(1-\eta)\right]-\left[\left(Q_{a}+Q_{w}\right) c\right]
$$

along with the initial condition

$$
c(t=0)=c_{o}
$$

The analytical solution to Eq. (1a) subject to initial condition Eq. (1b) becomes:

$$
\left[\frac{c-\frac{a}{b}}{c_{0}-\frac{a}{b}}\right]=e^{-a t} \text {. }
$$

where

$$
a \equiv \frac{\eta Q_{w}+Q_{a}}{V_{R}} \text { and } b \equiv \frac{Q_{a} c_{a}}{\eta Q_{w}+Q_{a}}
$$

The ultimate cleanup concentration within the recirculation cell and in the downstream effluent back into the aquifer becomes:

$$
c(t \rightarrow \infty) \equiv c_{\infty}=\left(\frac{Q_{a}}{\eta Q_{w}+Q_{a}}\right) c_{a}=\frac{b}{a}
$$

\subsection{Plug-Flow Model and Limitations}

Above the CSTR model assumes infinite mixing occurs within the recirculation cell. On comparing the actual velocity fields produced in the flow model, transport timing from the exhaust to the intakes of each ARW varies from months to years. If we now look at the opposite extreme of no vertical mixing (i.e., longitudinal dispersion) within the recirculation cell a PlugFlow model is obtained. A schematic of the Plug-Flow model is presented in Figure 15. The 
primary difference between this model and the CSTR model is that the recirculation cell has now been broken up into multiple finite volumes that reduces the level of vertical mixing achieved.

Applying a contaminant species mass balance over each finite volume within the recirculation cell the following set $(\mathrm{m})$ of $1^{\text {st }}$ order linear ordinary differential equations is obtained:

For the first cell $(\mathrm{i}=1)$

$$
\mathrm{V}_{1} \frac{\mathrm{dc}}{\mathrm{dt}}=\left[\mathrm{Q}_{\mathrm{w}} \mathrm{c}_{\mathrm{m}}(1-\eta)\right]-\left[\left(\mathrm{Q}_{\mathrm{a}}+\mathrm{Q}_{\mathrm{R}}\right) \mathrm{c}_{1}\right]
$$

For the intermediate cells $(\mathrm{i}=2, \ldots, \mathrm{m}-1)$

$$
V_{i} \frac{d c_{i}}{d t}=Q_{R}\left(c_{i-1}-c_{i}\right)
$$

For the last cell $(\mathrm{i}=\mathrm{m})$

$$
\mathrm{V}_{\mathrm{m}} \frac{\mathrm{dc} m}{\mathrm{dt}}=\mathrm{Q}_{\mathrm{a}} \mathrm{c}_{\mathrm{a}}+\mathrm{Q}_{\mathrm{R}} \mathrm{c}_{\mathrm{m}-1}-\mathrm{Q}_{\mathrm{w}} \mathrm{c}_{\mathrm{m}}
$$

along with the initial conditions $(\mathrm{i}=1, \ldots, \mathrm{m})$

$$
c(t=0)=c_{o}
$$

The solution to Eqs. $(4 a, b, c)$ subject to initial conditions Eq. (4b) were solved numerically. The equations were differenced implicitly and then solved by Picard's iteration (forward marching) at each time step. Stability and accuracy issues were addressed by the use of a large number of cells and small time steps.

\subsection{FACT-Transport Model and Limitations}

As mentioned above and using the grid employed in the FACT-Flow model, a FACT based transport model for TCE was developed. The primary purpose of developing this model and performing the simulations was to assess the validity of the CSTR and Plug-Flow models. The main features unique to this transport model are:

- The longitudinal and transverse dispersivities in the horizontal plane, $\alpha_{\mathrm{LH}}$ and $\alpha_{\mathrm{TH}}$, were set to $1 \%$ of the width of the model grid, 30 feet.

- The longitudinal and transverse dispersivities in the vertical direction, $\alpha_{\mathrm{LV}}$ and $\alpha_{\mathrm{TV}}$, were set to $0.1 \%$ of the width of the model grid, 3 feet.

- The equilibrium distribution coefficient between soil and mobile water phase, $\mathrm{k}_{\mathrm{d}}$, was set to $0.00128 \mathrm{ml} / \mathrm{g}$. 
- No upstream time varying source terms were accounted for. The incoming TCE at the North face of the model domain was set to $3000 \mathrm{pbb}$ and held stationary at that value throughout the simulations.

- An initial uniform TCE concentration field of $3000 \mathrm{ppb}$ used assumed.

- The FACT-Flow model grid was employed and no alterations were considered to optimize on transport results.

- The liquid mass flowrate of TCE entering each intake screen (i.e., concentration multiplied by volumetric flowrate) was adjusted based on the single-pass efficiency factor $(\eta=70 \%)$ to account for vapor-phase extraction. This reduced (by the factor 1- $\eta$ ) liquid mass flowrate was then re-injected into the exhaust screen of each ARW as a TCE line source.

An ultimate cleanup efficiency is defined as:

$$
\Omega \equiv 100\left(\frac{c_{a}-c_{\infty}}{c_{a}}\right)
$$

This cleanup percentage is computed based on the long-term impact of the ARWs in operations.

\subsection{Unmitigated TCE Plume}

To estimate the TCE concentration levels in the vicinity of the ARWs a 2-D fit of dissolved TCE concentration was supplied by (Jackson, D. G., Jr. and Looney, B. B., 1999). This TCE plume was generated by making an EarthVision ${ }^{\mathrm{TM}}$ 2-D spline (with tension) fit of the data provided in (White, R. M., 1999). The data used in the fitting process was selected from the time period prior to the initial operation of either ARW.

Given the 2-D spline fit of the available TCE plume an estimate is made of the average TCE concentration within the inlet region of the predicted capture zone. Based on the predicted 3-D pathlines upstream of the ARWs, a y-plane (i.e., a constant SRS Northing value) was selected where the pathlines vertically approach the same shape as dictated by the local hydrostratigraphy (e.g., see Figure 19). This $y$-plane $(99536.2 \mathrm{~N}$, at $\mathrm{j}=52$ ) is defined as our inlet region into the capture zone. The location of this y-plane is shown in Figure 4.

Based on the computed 3-D pathlines for the Nominal-A case, the capture zone boundary crossing through this y-plane was determined and is shown in Figure 25. Numerical integration of the TCE plume within the interior of this capture zone boundary resulted in an average TCE concentration of approximately $3000 \mathrm{ppb}$. This concentration value is used as the inlet and initial value for the mass balance and transport calculations to follow. 


\subsection{Flow Model Results}

Capture zone analyses for SSR-011 and SSR-012 were performed for three nominal pumping scenarios and ten sensitivity runs (Table 7). Three-dimensional particle tracking from the lower and upper screens of each well was used to compute volume streamtraces in Tecplot ${ }^{\circledR}$ (Amtec, 1998) of the pore nodal velocity field computed by the FACT simulations.

The starting points (seeds) for the volume streamtraces were eight equally spaced points azimuthally around the perimeter of the each well screen repeated every foot along the length of the screen. Reverse particle tracking was used for the lower (extraction) screens and Forward particle tracking for the upper (injection) screens.

To visualize the three-dimensionality of the capture and rejection zones, orthographic projections, $\mathrm{XY}$ and $\mathrm{YZ}$ projections of the capture and rejections zones were generated for the Nominal-A case.

\subsection{Flow Simulations}

A series of fourteen steady-state groundwater flow simulations in the vacinity of SSR-011 and SSR-012 were completed. A base case (calibrated flow model), three nominal pumping scenarios and 10 parameter sensitivity runs. Calibration of the groundwater flow model to the potentiometric map of the LLAZ established the "base case". The three nominal pumping scenarios demonstrate the influence of the regional flow on the capture and rejection zones for the pumps operating alone or in tantum. The parameter sensitivity runs show the impact of variations in hydraulic properties and differential pumping rates on the capture zones.

\subsection{Base Case}

The base case represents the calibrated regional groundwater flow in the "Lost Lake" aquifer zone without pumping. The computed potentiometric map with 5-year timing markers is shown in Figure 12. The agreement with the 2-D grid of potentiometric map of LLAZ (Figure 11) is excellent. A particle entering the north face of the mesh takes about 20 years to exit the south face, 3000 feet down gradient.

\subsection{Nominal-A Case (both ARWs operating)}

The XY projection of the capture zone for SSR-011 and SSR-012 is shown in Figure 16. The red streamtraces are associated with SSR-011 and the cyan streamtraces with SSR-012. The red circles show the locations of the SSR ARW network within the model domain. The computed capture zone width is 684 feet (Table 8). An orthographic projection of the three-dimensional streamtraces of the capture zone for both ARW's is shown in Figure 17. . An orthographic projection of the three-dimensional streamtraces of the rejection zone for both ARW's is shown in Figure 18. A YZ projection of the capture and rejection zones with 1-year timing markers through the center of SSR-011 are shown in Figures 19 and 20, respectively. . A YZ projection 
of the capture and rejection zones with 1-year timing markers through the center of SSR-012 are shown in Figures 21 and 22, respectively.

A good indication of the areal extent of the recirculation cell can be obtained by looking at the vertical pore velocity field. In Figure 23 shaded contour intervals of the vertical pore velocity is plotted for the $\mathrm{z}$ plane $\mathrm{k}=25$. This $\mathrm{z}$ plane represents approximately the vertical center of the aquifer. Also, shown are the locations of the various SSR wells and their neighboring SSM wells. The vertical distance between intake and exhaust screens varies from 20 to 30 feet. Pore velocities of $-0.1 \mathrm{ft} / \mathrm{d}$ represent travel times on the order of 200 to 300 days. Figure 24 is a zoom in of Figure 23 where a closer look at the contours near each ARW can be seen. ARW SSR-012 has lower vertical velocities than SSR-011. This is a result of the asymmetrical arrangement of the two ARWs with respect to the natural groundwater flow field. ARW SSR-012 captures more of the upstream aquifer groundwater while SSR-011 recycles more. In the very near vicinity of each ARW pore velocities of $-2.0 \mathrm{ft} / \mathrm{d}$ are computed. Pore velocities of $-2.0 \mathrm{ft} / \mathrm{d}$ represent travel times on the order of 10 to 15 days.

In order to perform simple mass balance calculations the upstream capture zone of the ARWs must be determined. The upstream capture zone can be seen by passing a y-plane slice through the 3-D grid upstream of both ARWs. Based on Nominal-A FACT flow results, Figure 25 contains the image corresponding to the $j=72 \mathrm{y}$-plane (SRS Northing $=99,536.2 \mathrm{ft}$ ). Also shown in this figure is the TCE contour plume based on an EarthVision ${ }^{\mathrm{TM}}$ 2-D spline fit with tension of the local data provided in Table 5-X (see Dennis table). The bullets piercing this vertical plane are grouped into two colors/shapes (i.e., red circles for SSR-001 and cyan squares for SSR-012) and represent the $(x, z)$ coordinates where the pathlines associated with each well cross. The vertical screen heights for the two ARWs and several of their neighboring SSM wells are also shown. A polygon created by encircling all of these bullets represents the upstream composite capture zone. By integrating the y-component Darcy velocity over this polygon, the volumetric flowrate entering the ARWs as input from the aquifer can be computed. For the Nominal-A case the result is:

- Volumetric flowrate in aquifer capture zone, $\mathrm{Q}_{\mathrm{a}}=16.4 \mathrm{gpm}$; resulting in

- Volumetric flowrate in recirculation cell $\mathrm{Q}_{\mathrm{R}}=2(43) \mathrm{gpm}-\mathrm{Q}_{\mathrm{a}}=51.6 \mathrm{gpm}$.

These, as well as other key parameters, are tabulated in Table 8 (summary table of nominal and sensitivity results). These pathlines, shown as bullets in Figure 25, are reverse back-tracking streamlines generated interactively within the commercially available graphical package TecPlot ${ }^{T M}$. These pathlines originated as seeds located on the surface of the intake screens for both ARWs (i.e., for each intake screen 88 uniformly placed seeds were used corresponding to 11 axial layers and 8 azimuthal sectors). As shown in the figure, the composite capture zone extents the majority of the vertical extent of the Lost Lake Aquifer Zone. 


\subsection{Nominal-B Case (ARW SSR-011 operating only)}

The computed capture zone width for SSR-011 operating alone at $43 \mathrm{gpm}$ is 454 feet (Table 8). The XY projection of the capture zone is shown in Figure 30.

\subsection{Nominal-C Case (ARW SSR-012 operating only)}

The computed capture zone width for SSR-012 operating alone at $43 \mathrm{gpm}$ is 485 feet (Table 8). The XY projection of the capture zone is shown in Figure 31.

The Nominal-C case is unique in that actual operation of this ARW has been in progress over the last several years. SSR-012 was install in December of 1996, then redeveloped in April of 1997, and operated until shutdown in September of 1997 with other operating periods to date. The locations of the two install ARWs and their neighboring monitoring wells is listed in Table 4. In (White, R. M., 1999) dissolved TCE and oxygen concentration measurements for the various wells listed in Table 4 were taken over the time period of December 1996 to January of 1998. Inferences are made as to the flow behavior under ARW operation and potential regions of high levels of contaminant using this data base (see White, R. M., 1999).

To provide further assistance in assessing/understanding the flow behavior under ARW operation, 3-D pathlines computed from the FACT-Flow model results for Nominal-C case have been generated. Three of the neighboring monitoring well clusters (both their upper and lower screens $C$ and $B$, respectively) have been chosen for this study:

- SSM-003B and SSM-003C - These wells are located approximately $20 \mathrm{ft}$ north of the SSR012 ARW;

- SSM-004B and SSM-004C - These wells are located approximately $20 \mathrm{ft}$ south of the SSR012 ARW; and

- SSM-007B and SSM-007C - These wells are located approximately $190 \mathrm{ft}$ east of the SSR012 ARW.

For each well cluster (that contains a lower screen B and an upper screen C) both forward and reverse 3-D pathlines were generated starting at the location of each screen. Four seeds uniformly placed along each screen height were used. The results of these particle tracking calculations are discussed below for each well cluster separately.

For the SSM-003B and SSM-003C wells, their 3-D pathlines are shown in Figures 32 and 33. Time markers representing a 7.0 day duration is plotted. Figure 32 provides a vertical perspective, while Figure 33 is a plan view. The lower screen B resides within the inlet capture zone of SSR-012 and the upper screen $C$ is completely within the ARW recirculation cell. For the B screen it takes $\sim 1$ week for water to travel from this screen to the intake srceen of the ARW, while it takes $\sim 13-24$ months for water to travel from the capture zone inlet to the $B$ screen. Note that the water passing through the B screen is essentially a vertical averge of the upstream LLAZ water taken from the same inlet region when the ARW in not operating. For the 
C screen it takes $\sim 2-4$ weeks for water to travel from this screen to the intake screen of the ARW, while it takes $\sim 1$ week for water to travel from the ARW exhaust screen to the $C$ screen. See Figure 26 of (White, R. M., 1999) for the TCE concentration at SSM-003B\&C over this time period. During ARW operation the TCE concentration level at screen $C$ dropped signficantly over a 8 week time period and then remained low even after the ARW was shutdown. On the other hand, during the same time period of operation the TCE concentration level at screen B remained essentially constant with superimpose fluctuations about this mean.

For the SSM-004B and SSM-004C wells, their 3-D pathlines are shown in Figures 34 and 35. Time markers representing a 7.0 day duration is plotted. Figure 34 provides a vertical perspective, while Figure 35 is a plan view. Both screens reside completely within the ARW recirculation cell. For the B screen it takes $\sim 1$ week for water to travel from this screen to the intake srceen of the ARW, while it takes $\sim 3-12$ months for water to travel from the ARW exhaust screen to the B screen. For the $C$ screen it takes $\sim 2-5$ weeks for water to travel from this screen to the intake screen of the ARW, while it takes $\sim 1$ week for water to travel from the ARW exhaust screen to the $C$ screen. Note that the water passing through the $B$ screen versus the $C$ screen takes a significantly longer travel time going from the ARW exhaust screen to its intake screen. See Figure 27 of (White, R. M., 1999) for the TCE concentration at SSM-004B\&C over this time period. During ARW operation the TCE concentration level at screen $C$ dropped only slightly over a 3 month time period and then remained low constant after the ARW was shutdown. On the other hand, during the same time period of operation the TCE concentration level at screen B remained essentially constant with large superimpose fluctuations about this mean.

For the SSM-007B and SSM-007C wells, their 3-D pathlines are shown in Figures 36 and 37. Time markers representing a 36.5 day duration is plotted. Figure 36 provides a vertical perspective, while Figure 37 is a plan view. Both screens reside within the inlet capture zone of SSR-012. For the B screen it takes $\sim 3$ months for water to travel from this screen to the intake srceen of the ARW, while it takes $\sim 19$ months for water to travel from the capture zone inlet to the B screen. Note that the water passing through the B screen is essentially from the same inlet region when the $A R W$ in not operating. For the $C$ screen it takes $~ 8-13$ months for water to travel from this screen to the intake screen of the ARW, while it takes $\sim 25$ months for water to travel from the capture zone inlet to the $C$ screen. Note that the water passing through the $C$ screen is being pulled down from the upper region of the Lost Lake Aquifer Zone. It takes $\sim 8$ months to bring the water near the top of LLAZ down to the C screen. See Figure 31 of (White, R. M., 1999) for the TCE concentration at SSM-007B\&C over this time period. During ARW operation the TCE concentration level at screen $C$ dropped signficantly over a 1 year time period and then rose sharpely when the ARW was shutdown. On the other hand, during the same time period of operation the TCE concentration level at screen B remained essentially stationary.

\subsection{Sensitivity Cases}

In order to address the potential uncertainties associated with predicting the capture zones for the two ARWs modeled, a series of sensitivity case runs were chosen for consideration. Based on the descriptions of the three mass balnace models discussed in Chapter 4, a list of sensitivity 
parameters were selected. The selected sensitivity parameters and their estimated upper/lower bounds are tabulated in Table 7, along with their nominal settings. The size and shape of inlet capture zones are primarily a function of the pumping rates of each ARW. To a secondary degree capture zones are also a function of the hydraulic conductivities (i.e., both horizontal and vertical properties) of the aquifer system. On the other hand, aquifer porosity effects the particle speeds (i.e., pore speed) but does not impact capture zone shapes. The upper and lower bounds chosen reflect engineering judgement and the available data pertenient to this area.

A summary of the key flow results obtained for the above mentioned series of nominal and sensitivity cases is provided in Table 8. Mean values and standard deviations are also provided. The last column, listing the ratio of flowrate within the recirculation cell to that within the ARWs, provides some measure as to the degree of recycling that occurs.

For the Nominal-A case we see overlaping of individual capture zones has occurred, resulting in a reduced overall capture width of $684 \mathrm{ft}$ when compared to the individual pumping cases of 454 $\mathrm{ft}$ and $485 \mathrm{ft}$, respectively. This overlaping results from: (1) the placement of each well $\sim 255 \mathrm{ft}$ apart and (2) the off-alignment of the well network with respect to the natural groundwater head gradient (i.e., a 50 to 60 degree offset exists). Also, the combined pumping case increases its overall recycling ratio from about $52 \%$ for individual pumping scenarios to $81 \%$. Increased recycling increases the level of contaminant extracted (i.e., lower concentration levels ultimately rejected back to the downstream aquifer) at the price of reduced throughput.

The mean values and standard. deviations computed and placed at the bottom rows of the table are based on just those cases whose pumping rates are at their nominal values (i.e., Nominal-A, Sensitivity-(A,B,C,D,I, and J)). Pumping rates are controllable parameters whose uncertainties should be small when compared to the other parameters listed. The impact of varying either pumping flowrate up or down is given in Sensitivity-(D,E,F, and G) cases, while the individual pumping cases are Nominal-(B and $\mathrm{C}$ ).

From this sensitivity study the following general trends are observed:

- By lowering the vertical hydraulic conductivity of the material, increased capture widths are seen. Physically, this can be explaned as the broadening of the horizontal extent to compensate for the increased resistance to vertical flows.

- No impact is observed on capture width or recirculation cell upon a variation in the material's "effective" porosity. As mentioned above, porosity directly impacts pore speeds (i..e, magnitude of velocity) but does not alter the velocity vector field direction. It is this vector field directions that dictate the locations of the pathlines, while speed controls the travel times.

- By increasing the horizontal hydraulic conductivity of the material, increased capture widths are seen. These results appear counter-intutive and at the time of writing this report no complete understanding of this trend can be provided here. 
The results tabulated in Table 8 are used in Chapter 6 below to estimate the cleanup characteristics of the ARWs in operation.

\subsection{Mass Balance Results}

To perform a consistent comparison between the results of the CSTR, Plug-Flow, and FACTTransport models, the results from the Nominal-A case were used. A uniform initial TCE concentration of $3000 \mathrm{ppb}$ was applied throughout the model domains. Since the transport and extraction processes are assumed to be linear, the actual magnitude of initial TCE concentration is arbitrary (i.e., the results from all three approaches could be normalized by $3000 \mathrm{ppb}$ ). The normalized results could then be used in a generic manner for other conditions. A single-pass extraction efficiency of $70 \%$ was assumed. Simulations were performed for an ARW operating period of ten years.

For the CSTR and Plug-Flow models a single "composite" recirculation cell is modeled and from the Nominal-A case results the following hydraulic results were obtained (see Table 8):

- Volume of recirculation cell, $\mathrm{Q}_{\mathrm{R}}=8306705.7 \mathrm{ft}^{3}$

- Volumetric flowrate in aquifer capture zone, $\mathrm{Q}_{\mathrm{a}}=15.18 \mathrm{gpm}$

- Total volumetric flowrate through both $\mathrm{ARWs} \mathrm{Q}_{\mathrm{w}}=43+43=86 \mathrm{gpm}$

The results based on the above three models are shown in Figure 26 where the TCE concentration exiting the recirculation cell and returning to the aquifer system is plotted versus time. As expected the CSTR model conservatively over-predicted this concentration (i.e., underpredicts TCE extraction) throughout the entire time period. For the Plug-Flow model a rapid drop in concentration occurs early on. Basically, the initial concentration of $3000 \mathrm{ppb}$ is reduced to $30 \%$ of its value $(-900 \mathrm{ppb})$ immediately, with a plateau region at $900 \mathrm{ppb}$ occurring for approximately 1.5 years. The average transport time from the exhaust -to-intake is on the order of 1.5 years within the "composite" recirculation cell.

FACT-Transport simulations were also performed. For early times (zero to 3 years) the transport time step size used was reduced to 3.65 days in order to maintain reasonablely small time step truncation errors. Results for time step sizes 3.65 and 36.5 days were compared. The larger step size appears to be adequate for times beyond 3 years.

Figure 26 also shows the results from the FACT-Transport model for each ARW separately. SSR-011 has a significantly lower exit concentration than well SSR-012. This is primarily due to the fact that SSR-011 receives a modest fraction of its input from the exhaust of SSR-012. The FACT-Transport model results drop rapid early on and drop further than the Plug-Flow model's. The differences are the result of: (1) a range of transport times exist between the exhaust -tointake screens where the Plug-Flow model represents an average value and (2) the FACTTransport model over simulates the longitudinal dispersion between the two screens as well. The actual behavior should fall within the bounds of the Plug-Flow and FACT-Transport model 
results. However, the simpler Plug-Flow model appears to be a reasonable predictor of extraction behavior at only a small fraction of the cost and time necessary for performing a 3-D transport simulation.

The rate of TCE mass extraction for each of the three model predictions is shown in Figure 27. Rates on the order of 1 to $2 \mathrm{lbm} /$ day total are predicted over the first couple of years.

The predicted ultimate cleanup percentages for the Nominal-A case are:

- CSTR Model, $\Omega=80 \%$;

- Plug-Flow Model, $\Omega=93 \%$;

- FACT-Transport Model (SSR-011), $\Omega=92 \%$; and

- FACT-Transport Model (SSR-012), $\Omega=87 \%$.

To gain some insight into the impact of uncertainty on the cleanup behavior, a series of sensitivity FACT-Flow model runs were made. The parameters chosen to perform sensitivity analayses on and their parameter ranges are listed in Table 7. A summary of the key hydraulic results from the FACT flow simulations is provided in Table 8 . With this data mass balance calculations for each case were made using the Plug-Flow model. Figure 28 shows the normalized TCE concentrations exiting the "composite" ARW as a function of time after startup. Based on the plug flow assumptions, early on (i.e., first 1 to 2 years) the plateau region is unaffected by the hydraulic uncertainties. However, this plateau region is directly efected by the assumed single-pass extraction efficiency (a constant value of $70 \%$ in Figure 28).

Figure 29 shows the FACT-Transport model predicted TCE concentration profile after one year of ARW operations for the Nominal-A case. A cutaway has been performed to highlight the region where both ARWs are located. TCE concentrations above $2500 \mathrm{ppb}$ have been blanked out to better enhance the vissual perspective of the contour surrounding the two ARWs. As shown in Figure 29, TCE concentration levels under $\sim 1500 \mathrm{ppb}$ are entering the intake screens after one year of operation.

\subsection{References}

Aadland, R. K., Gellici, J. A., and Thayer, P. A., 1995a. Hydrogeologic Framework of WestCentral South Carolina, Report 5, Water Resources Division, South Carolina Department of Natural Resources, Columbia, SC.

Aadland, R. K., Lewis, S. E., and McAdams, T. D., 1995b. Hydrogeological Characterization Report for the A/M Area (U). WSRC-RP-95-0052, Westinghouse Savannah River Company, Aiken, SC 29808.

Amtec Engineering, Inc., 1998. Tecplot ${ }^{\oplus}$ Version 7.5. Amtec Engineering, Inc., Bellevue, WA. 
Dynamic Graphics, Inc., 1997. EarthVision ${ }^{\circledR}$ 5.0. Dynamic Graphics, Inc., Alameda, CA 94501.

Hamm, L. L, Aleman, S. E., Flach, G. P., and Jones, W. F., 1999. FACT (Version 1.1)

Subsurface Flow and Contaminant Transport, Documentation and User's Guide (U), WSRC-TR95-0223, Rev. 1, Westinghouse Savannah River Company, Aiken, SC 29808.

Herrling, B. and Buermann, W., 1990. A New Method for In-Situ Remediation of Volatile Contaminants in Groundwater-Numerical Simulation of the Flow Regime, Computational Methods in Subsuface Hydrology, pages 299-304.

Hiergesell, R.A., 1993. Hydrologic Analysis of Data for the Lost Lake Aquifer Zone of the Steed Pond Aquifer at Recovery Well RWM-16 (U), WSRC-TR-92-529, Rev. 1, Westinghouse Savannah River Company, Aiken, SC 29808.

Hiergesell, R.A. and Pemberton, B. E., 1995. Final Report: Aquifer Testing with 2-inch Diameter Wells in the A/M Area Southern Sector (U), WSRC-TR-95-0365, Westinghouse Savannah River Company,.Aiken, SC 29808.

Jackson, D. G., Jr. and Looney, B. B., 1996. Development of a Vertical Recirculation Well System for the A/M Area of the Savannah River Site (U), WSRC-RP-96-477, Westinghouse Savannah River Company, Aiken, SC 29808.

Jackson, D. G., Jr. and Looney, B. B., 1999. Personal communication and data transfer.

Smits, A. D., Harris, M. K., Jackson, D. G. Jr., and Hawkins, K. L., 1999. Baseline Mapping Study of the Steed Pond Aquifer and Crouch Branch Confining Unit Beneath A/M Area, Savannah River Site, Aiken, South Carolina (U), WSRC-TR-98-00357, Revision 1, Westinghouse Savannah River Company, Aiken, SC 29808.

White, R. M., 1999. Airlift Recirculation Well Final Report - Southern Sector (U), WSRC-TR98-00428, Rev. 0, Westinghouse Savannah River Company, Aiken, SC 29808. 
WESTINGHOUSE SAVANNAH RIVER COMPANY

Capture Zone Analyses of Two Airlift Recirculation Wells in the Southern Sector of A/M Area
Report:

Revision:

Date:

Page:
WSRC-TR-99-00203

0

$6 / 99$

22 of 66

\section{TABLES}


Table 1. Hydrostratigraphic "Picks" of the"Lost Lake" Aquifer Zone

\begin{tabular}{|c|c|c|c|c|c|}
\hline Core $\mathbf{W}$ & SRS Easting & SRS Northing & $\begin{array}{l}\text { Surface } \\
\text { Elevation } \\
\end{array}$ & $\begin{array}{r}\mathbf{L A O Z} \\
\quad \\
\end{array}$ & $\begin{array}{l}\mathrm{CB} \mathrm{CBU} \\
\text { upper; } \\
\text { interval }\end{array}$ \\
\hline AMB-13A & 51396.00 & 103082.00 & 362.90 & 185 & 148 \\
\hline ASB-2CR & 52862.70 & 105540.20 & 353.10 & 186 & 156 \\
\hline ASB $6 A A$ & 52643.90 & 105727.00 & 351.80 & 188 & 140 \\
\hline GCB:1 & 46074.39 & 100006.75 & 335.80 & 180 & 124 \\
\hline GCB-2 & 50599.70 & 95924.90 & 221.00 & 166 & 127 \\
\hline $\mathrm{GCB}: 3$ & 55502.72 & 103488.45 & 255.70 & 192 & 141 \\
\hline MBC-1SB & 52780.00 & 108450.00 & $371.80^{\circ}$ & 185 & 128 \\
\hline MBC-2SB & 52975.00 & 107750.00 & $379.80^{\circ}$ & 174 & 130 \\
\hline MBC-3SB & 52035.00 & 107178.00 & 366.80 & 211 & 125 \\
\hline MBC-4SB & 51445.00 & 105008.00 & 380.80 & 188 & 129 \\
\hline MBC-5SB & 51641.00 & 103983.00 & 370.80 & 196 & 126 \\
\hline MBC-6SB & 51234.50 & 101346.40 & 326.80 & 186 & 127 \\
\hline $\mathrm{MBC}-7 \mathrm{SB}^{2}$ & 48750.00 & 100850.00 & 328.80 & 196 & 145 \\
\hline MBC-8SB & 52189.41 & 107798.58 & 380.00 & 190 & na \\
\hline MBC-9SB & 54286.40 & 108646.70 & 349.80 & 197 & 130 \\
\hline $\mathrm{MBC}-10 \mathrm{SB}$ & 52302.92 & 105042.00 & 359.80 & 182 & 137 \\
\hline MBC-11SB & 51937.25 & 103090.50 & 360.80 & 194 & 117 \\
\hline$M B C-12 S B$ & 50284.19 & 101570.50 & 336.80 & 191 & 156 \\
\hline MBP-1SB & 45069.00 & 96903.00 & 317.80 & 182 & 118 \\
\hline $\mathrm{MBP}-2 \mathrm{SB}$ & 45012.00 & 97490.00 & 336.70 & 183 & 117 \\
\hline $\mathrm{MBP}=\mathbf{4} \mathrm{SB}$ & 43476.00 & 97469.00 & $372: 70$ & 192 & 146 \\
\hline MBP-5SB & 43986.00 & 97264.00 & 360.50 & 184 & 151 \\
\hline$M \overrightarrow{M B}-\overline{G B}$ & 45264.00 & 97705.00 & 318.70 & 191 & 142 \\
\hline MBP $-7 \mathrm{SB}$ & 43264.00 & 98839.00 & 345.00 & 187 & 157 \\
\hline MHT-1C & 48765.60 & 102706.80 & 362.70 & 198 & na \\
\hline MSB-2B & 48748.20 & 101997.90 & 352.30 & 196 & 163 \\
\hline MSB $=4 \mathrm{C}$ & 48313.60 & 101963.20 & 353.10 & 201 & 160 \\
\hline MSB-5B & 46983.60 & 101971.10 & 343.10 & 194 & 164 \\
\hline $\mathrm{MSB}-\overline{G B}$ & 46321.60 & 101148.50 & 341.80 & 191 & 163 \\
\hline MSB-7B & 46718.10 & 100597.60 & 342.10 & 188 & 154 \\
\hline MSB 13CC & 47525.70 & 101728.80 & 344.80 & 195 & 157 \\
\hline $\mathrm{MSB}-32 \mathrm{~B}$ & 52742.50 & 99676.00 & 253.50 & 196 & 167 \\
\hline MSB $48 \mathrm{C}$ & 54077.00 & 107917.50 & 360.20 & 200 & 163 \\
\hline MSB $62 \mathrm{~B}$ & 47906.80 & 101865.30 & 347.00 & 200 & 157 \\
\hline MSB-66TA & 51096.70 & 105842.60 & 380.50 & 198 & 162 \\
\hline MSB-67B & 51989.60 & 106842.00 & 362.70 & 185 & 161 \\
\hline MSB-7.1B & 44054.70 & 103801.60 & 342.90 & 198 & 173 \\
\hline MSB-72B & 48350.30 & 96387.60 & 326.70 & 188 & na \\
\hline MSB-77TA & 54208.90 & 107053.80 & 354.90 & 189 & 154 \\
\hline MSB-81B & 55230.40 & 103762.70 & 265.10 & 196 & 150 \\
\hline MSB-82C & 51949.40 & 107521.90 & 371.70 & 190 & 161 \\
\hline MSB-83C & 52384.70 & 108405.30 & 369.80 & 193 & 168 \\
\hline MSB-84C & 51973.70 & 108967.90 & 359.90 & 196 & 171 \\
\hline MSB-85C & 53151.40 & 107835.20 & 378.60 & 178 & na \\
\hline
\end{tabular}




\begin{tabular}{|c|c|c|c|c|c|}
\hline Core ID & $\begin{array}{l}\text { SRS Easting } \\
\text {. }\end{array}$ & 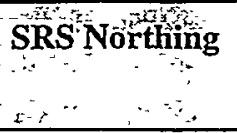 & Surface & 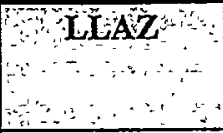 & $\begin{array}{l}\text { EBcề } \\
\text { "uppeis" } \\
\text { interval }\end{array}$ \\
\hline MSB-87B & 51607.00 & 101276.00 & 334.00 & 190 & 147 \\
\hline MSB: $8 \overline{8}$ & 50774.20 & 97013.00 & 235.80 & 190 & 116 \\
\hline $\mathrm{MSB}=89 \mathrm{~B}$ & 47889.90 & 98374.10 & 337.30 & 185 & 139 \\
\hline$\therefore$ MSÖ-1̄SB & 51185.90 & 97717.70 & 261.80 & 184 & 132 \\
\hline MSS-2SB & 47963.40 & 96992.10 & 298.80 & 182 & 129 \\
\hline $\mathrm{MSS}-3 \mathrm{SB}$ & 50336.50 & 99594.20 & 318.80 & 194 & 139 \\
\hline MSS-4SB & 50308.70 & 100442.00 & 337.80 & 195 & 133 \\
\hline MS̈S-5SB & 51469.90 & 99842.90 & 304.80 & 189 & 144 \\
\hline MSS-6SB & 51541.00 & 97682.90 & 252.80 & 177 & 121 \\
\hline MSS-7SB & 49715.60 & 98180.60 & 297.80 & 195 & 133 \\
\hline ṀSS-8SB & 53943.40 & 98545.00 & 283.80 & 185 & 127 \\
\hline MSS-9SB & 49477.90 & 96996.90 & 316.80 & 191 & 137 \\
\hline MSS-10SB & 45674.00 & 98159.00 & 305.80 & 188 & 123 \\
\hline MW-1SB & 48128.00 & 104396.00 & 345.80 & 189 & 137 \\
\hline$M: W-2 S B$ & 46629.00 & 102653.00 & 347.80 & 193 & 148 \\
\hline MW-3SB & 45752.00 & 102982.00 & 347.80 & 187 & 158 \\
\hline MW-4SB & 45441.00 & 104523.00 & 350.80 & 185 & 140 \\
\hline MW-5SB & 44618.00 & 105553.00 & 334.80 & 191 & 150 \\
\hline$M \dot{W}-6 S B$ & 47954.00 & 105098.00 & 337.80 & 188 & 130 \\
\hline MW-7SB & 45680.41 & 103726.41 & 358.00 & 197 & 141 \\
\hline $\mathrm{M}: \mathrm{W}=8 \mathrm{SB}$ & 44790.40 & 103199.01 & 357.50 & 190 & 149 \\
\hline MW-9SB & 43880.29 & 102934.67 & 353.80 & 191 & 139 \\
\hline $\mathrm{MW}=10 \mathrm{SB}$ & 43994.16 & 101446.29 & 367.90 & 193 & 149 \\
\hline MW $1 \mathrm{SSB}$ & 44951.23 & 100621.11 & 358.10 & 198 & 146 \\
\hline $\bar{M} \bar{W}=\mathbf{S B}$ & 48163.57 & 103608.04 & 348.40 & 186 & 143 \\
\hline MMY $\overline{M S B}$ & 42730.26 & 102465.26 & 361.40 & 192 & 139 \\
\hline $\mathrm{MW}-14 \mathrm{SB}$ & 42195.92 & 102846.99 & 341.50 & 195 & 137 \\
\hline $\mathrm{P} 030 \mathrm{TA}$ & 57104.50 & 98933.30 & 355.10 & 210 & 141 \\
\hline RWM $13 \mathrm{~B}$ & 53516.30 & 105803.30 & 333.20 & 185 & 154 \\
\hline$\therefore \mathbf{R W M}=\mathbf{1} \mathbf{B}$ & 53044.70 & 106362.10 & 348.50 & 186 & 147 \\
\hline $\mathrm{RWMM}=15 \mathrm{~B}$ & 53849.00 & 107444.70 & 365.90 & 192 & 168 \\
\hline RWM 16 & 48244.80 & 97647.20 & 318.40 & 197 & 140 \\
\hline STRW $3 B$ & 41845.60 & 103526.60 & 330.30 & 209 & 136 \\
\hline SSR 001 & 48244.0 & 97272.5 & 318.64 & 196 & 138 \\
\hline OSSR 002 & 48431.0 & 97446.3 & 314.61 & 195 & 137 \\
\hline $\mathrm{SSR} 003$ & 48619.0 & 97612.9 & 318.40 & 199 & 137 \\
\hline$\quad S S R=004$ & 48802.0 & 97777.3 & 319.71 & 191 & 147 \\
\hline SSR-0005 & 48985.0 & 97948.9 & 315.98 & 194 & 149 \\
\hline SSR 006 & 49177.0 & 98117.9 & 311.29 & 194 & 148 \\
\hline SSR-007 & 49363.0 & 98291.4 & 307.63 & 197 & 155 \\
\hline SSR 008 & 49537.0 & 98470.5 & 303.42 & 192 & 137 \\
\hline SSR 009 & 49725.0 & 98653.3 & 295.38 & 192 & 138 \\
\hline SSR:010 & 49916.0 & 98802.9 & 271.57 & 191 & 143 \\
\hline SSR-011 & 50111.0 & 98972.3 & 283.16 & 190 & 143 \\
\hline SSR-012 & 50301.0 & 99142.6 & 307.95 & 198 & 142 \\
\hline
\end{tabular}


Table 2. Time Average Monitoring Well Hydraulic Head Measurements

\begin{tabular}{|c|c|c|c|c|c|}
\hline Well ID & $\begin{array}{r}\text { SRS Easting } \\
\text { (ft) }\end{array}$ & $\begin{array}{l}\text { SRS } \\
\text { Northing } \\
\text { (ft) }\end{array}$ & $\begin{array}{r}\text { Bottom of } \\
\text { Screen } \\
\text { (msil) }\end{array}$ & $\begin{array}{l}\text { Top of } \\
\text { Screen } \\
\text { (misi) }\end{array}$ & $\begin{array}{l}\text { Median } \\
\text { Hydraúlic } \\
\text { Head (ft) }\end{array}$ \\
\hline $\mathrm{ACB} 2 \mathrm{~A}$ & 51561.30 & 102367.40 & 207.8 & 237.8 & 239.20 \\
\hline $\mathrm{ACB} \cdot 3 \mathrm{~A}$ & 51313.30 & 102154.30 & 206.3 & 236.3 & 239.40 \\
\hline $\mathrm{ACB} 4 \mathrm{~A}$ & 51116.20 & 102343.90 & 211.7 & 241.7 & 238.80 \\
\hline$\triangle O B B$ & 50485.90 & 101910.70 & 218.5 & 248.5 & 236.10 \\
\hline AOB 2 & 50724.70 & 102009.80 & 220.2 & 250.2 & 236.15 \\
\hline AOB 3 & 50959.40 & 102164.40 & 223.9 & 243.9 & 238.00 \\
\hline MCB 2 & 45129.00 & 97012.60 & 205.9 & 225.9 & 225.40 \\
\hline MCB 6 & 45214.00 & 97425.70 & 199.7 & 219.7 & 219.20 \\
\hline MCB 6C & 45207.70 & 97413.10 & 165.0 & 170.0 & 196.10 \\
\hline MCB 10D & 45942.80 & 98300.10 & 224.9 & 244.9 & 238.80 \\
\hline MCB 10DR & 45942.50 & 98300.10 & 207.4 & 227.4 & 226.10 \\
\hline MCB 11B & 45392.10 & 96361.60 & 105.1 & 110.1 & 192.30 \\
\hline MCB 11C & 45383.60 & 96373.70 & 141.1 & 146.1 & 192.10 \\
\hline MCB 11D & 45374.90 & 96385.70 & 210.3 & 230.3 & 218.80 \\
\hline MCB 12B & 45246.10 & 98326.20 & 132.7 & 137.7 & 198.70 \\
\hline MCB 12C & 45236.60 & 98337.70 & 157.0 & 162.0 & 199.90 \\
\hline MSB 1A & 48467.30 & 101833.70 & 223.2 & 253.2 & 232.00 \\
\hline MSB 1B & 48483.20 & 101833.00 & 137.9 & 142.6 & 208.90 \\
\hline MSB 1C & 48512.70 & 101832.50 & 161.3 & 166.0 & 216.20 \\
\hline MSB 1CC & 48498.00 & 101832.50 & 187.8 & 192.5 & 218.00 \\
\hline MSB $10 ̈$ & 48452.20 & 101833.40 & 210.4 & 229.8 & 230.50 \\
\hline MSB：2A & 48746.40 & 102028.30 & 222.6 & 252.6 & 232.95 \\
\hline MSB 2B & 48748.20 & 101997.90 & 145.6 & 150.3 & 210.40 \\
\hline MSB 2C & 48749.30 & 101982.50 & 190.0 & 194.7 & 217.30 \\
\hline MSB 2D & 48755.70 & 102014.00 & 210.7 & 230.1 & 231.20 \\
\hline MSB 3A & 48553.70 & 102189.90 & 229.5 & 259.5 & 232.70 \\
\hline MŚB 3B & 48568.00 & 102191.70 & 141.1 & 145.8 & 210.90 \\
\hline MSB $3 \mathrm{C}$ & 48538.50 & 102189.60 & 189.0 & 193.7 & 218.70 \\
\hline MSB 3D & 48524.60 & 102188.60 & 211.2 & 230.7 & 230.45 \\
\hline $\mathrm{MSB} 4 \mathrm{AA}$ & 48313.00 & 101993.40 & 224.8 & 254.8 & 231.30 \\
\hline MSB 4B & 48312.80 & 101978.30 & 138.4 & 143.1 & 206.10 \\
\hline $\mathrm{MSB}$ 4C & 48313.60 & 101963.20 & 163.3 & 168.1 & 214.90 \\
\hline$\ddot{\mathrm{MSB}} \mathbf{4 \mathrm { D }}$ & 48311.70 & 102007.50 & 209.0 & 228.4 & 229.50 \\
\hline MSB $\mathbf{5 A}$ & 46998.70 & 101971.50 & 217.2 & 247.2 & 227.55 \\
\hline MSB $5 B$ & 46983.60 & 101971.10 & 131.4 & 136.1 & 207.60 \\
\hline MSB' 5C & 46968.60 & 101970.40 & 183.4 & 188.1 & 222.90 \\
\hline MSB 6A & 46319.90 & 101133.80 & 211.9 & 241.9 & 227.10 \\
\hline MSB $\cdot \mathbf{6 B}$ & 46321.60 & 101148.50 & 125.1 & 129.8 & 206.50 \\
\hline MSB $6 \mathrm{C}$ & 46324.10 & 101169.10 & 189.3 & 194.0 & 223.90 \\
\hline MSB 7A & 46726.10 & 100585.70 & 212.0 & 242.0 & 228.20 \\
\hline MSB 7B & 46718.10 & 100597.60 & 142.7 & 147.5 & 207.20 \\
\hline MSB 7C & 46709.10 & 100609.20 & 195.4 & 200.1 & 222.70 \\
\hline MSB 8A & 47293.20 & 100815.10 & 212.4 & 242.4 & 229.50 \\
\hline MSB 8B & 47281.90 & 100805.80 & 146.1 & 150.8 & 208.60 \\
\hline MSB 8C & 47264.60 & 100793.20 & 191.2 & 195.9 & 220.10 \\
\hline
\end{tabular}


Page:

\begin{tabular}{|c|c|c|c|c|c|}
\hline Wèll ஸ̂́ & $\begin{array}{l}\text { SRS Easting } \\
(\mathbf{f t}) \\
\end{array}$ & $\begin{array}{c}\text { SRSS } \\
\text { Northing } \\
\text { (ft) }\end{array}$ & 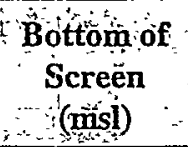 & $\begin{array}{c}\text { Top of } \\
\text { Screen } \\
\text { (msl) }\end{array}$ & $\begin{array}{l}\text { Median } \\
\text { Hydraulic } \\
\text { Head (ft })\end{array}$ \\
\hline MSB 9A & 48242.50 & 102236.70 & 139.2 & 144.2 & 209.40 \\
\hline MSB 9B & 48251.70 & 102239.40 & 204.3 & 209.3 & 229.95 \\
\hline MSB 9C & 48273.00 & 102245.60 & 221.6 & 241.6 & 231.20 \\
\hline MSB 10A & 47954.40 & 102451.80 & 120.2 & 125.2 & 210.30 \\
\hline MSB $10 \overline{\mathrm{B}}$ & 47943.10 & 102488.20 & 152.4 & 157.4 & 212.70 \\
\hline MSB 10C & 47951.10 & 102465.60 & 206.2 & 211.0 & 229.20 \\
\hline MSB 12A & 47141.00 & 102304.00 & 117.1 & 122.1 & 208.20 \\
\hline MSB 12 & 47142.10 & 102272.80 & 157.4 & 162.4 & 217.95 \\
\hline MSB 12C & 47140.90 & 102295.20 & 179.1 & 184.1 & 223.05 \\
\hline MSB 12D & 47142.20 & 102283.00 & 225.5 & 245.5 & 234.30 \\
\hline MSB 12T:A & 47130.40 & 102287.90 & 112.6 & 102.6 & 192.90 \\
\hline MSB 12TB. & 47131.50 & 102272.60 & -5.3 & 14.7 & 193.05 \\
\hline MSB 13A & 47525.40 & 101725.70 & 131.4 & 136.4 & 207.30 \\
\hline MSB 13B. & 47523.50 & 101735.70 & 172.5 & 177.5 & 199.30 \\
\hline MSB 13C & 47521.90 & 101745.70 & 224.1 & 244.1 & 229.30 \\
\hline MSB 13CC & 47525.70 & 101728.80 & 192.0 & 196.8 & 224.45 \\
\hline MSB 13D & 47517.50 & 101778.10 & 211.5 & 231.5 & 228.10 \\
\hline MSB 14A & 48521.90 & 101629.50 & 144.6 & 164.6 & 215.70 \\
\hline MSB 14B & 48519.10 & 101639.00 & 188.9 & 193.9 & 217.50 \\
\hline MSB 14C & 48517.30 & 101648.60 & 223.9 & 243.9 & 232.50 \\
\hline MSB 17A & 46245.70 & 101976.60 & 155.6 & 160.6 & 216.60 \\
\hline MSB 17B & 46237.70 & 101994.60 & 185.8 & 190.8 & 226.00 \\
\hline MSB-17BB & 46220.80 & 102009.50 & 132.6 & 137.3 & 212.50 \\
\hline MSB $17 \mathrm{C}$ & 46234.30 & 102004.60 & 233.9 & 253.9 & 213.15 \\
\hline$\overline{\mathrm{MSB}} 17 \mathrm{D}$ & 46226.20 & 102056.90 & 213.3 & 232.8 & 226.90 \\
\hline $\mathrm{MSB} 18 \mathrm{~A}$ & 46110.40 & 100416.10 & 158.9 & 163.9 & 212.50 \\
\hline MSB 18B & 46115.70 & 100424.10 & 193.5 & 198.5 & 222.00 \\
\hline MSB $18 G^{2}$ & 46121.40 & 100430.90 & 209.2 & 229.2 & 228.50 \\
\hline MSB 19A & 50934.40 & 100983.00 & 114.7 & 119.7 & 214.80 \\
\hline MSB $19 \widehat{B}$ & 50934.80 & 100999.30 & 142.7 & 147.7 & 217.00 \\
\hline MSB $10 \mathrm{C}^{-}$ & 50942.40 & 100992.10 & 198.7 & 218.7 & 238.90 \\
\hline $\mathrm{MSB} 22$ & 48508.80 & 102186.50 & 223.2 & 243.2 & 232.00 \\
\hline $\mathrm{MSB} 31 \mathrm{~A}$ & 50100.20 & 101979.30 & 12.0 & 22.0 & 198.00 \\
\hline $\mathrm{MSB} 31 \mathrm{~B}^{-}$ & 50078.70 & 101981.30 & 152.3 & 157.3 & 213.40 \\
\hline $\mathrm{MSB} 31 \mathrm{C}$ & 50089.90 & 101979.60 & 216.1 & 236.1 & 234.70 \\
\hline MSB 31CC & 50067.90 & 101983.10 & 176.7 & 181.4 & 213.70 \\
\hline MSB 32 & 52733.90 & 99655.60 & 198.1 & 218.1 & 224.85 \\
\hline MSB 32B & 52742.50 & 99676.00 & 127.5 & 132.5 & 211.90 \\
\hline MSB 32C - & 52746.90 & 99684.90 & 183.7 & 188.6 & 216.90 \\
\hline MSB 33 & 51736.30 & 98031.00 & 208.7 & 228.7 & 218.00 \\
\hline MSB 33A & 51738.00 & 98006.70 & 82.8 & 88.4 & 205.00 \\
\hline MSB 33B & 51741.90 & 97995.90 & 120.7 & 126.3 & 207.85 \\
\hline MSB 33C & 51746.70 & 97984.80 & 165.4 & 171.0 & 211.10 \\
\hline MSB 33TA & 51734.00 & 98018.20 & 18.1 & 23.4 & 194.90 \\
\hline MSB 35A & 50945.20 & 102098.00 & 123.2 & 128.8 & 216.60 \\
\hline MSB 35B & 50947.90 & 102110.80 & 163.7 & 169.3 & 219.50 \\
\hline
\end{tabular}


Capture Zone Analyses of Two Airlift Recirculation Wells

Page:

27 of 66

\begin{tabular}{|c|c|c|c|c|c|}
\hline Well WD & $\begin{array}{l}\text { SRS Easting } \\
\text { (ft) }\end{array}$ & $\begin{array}{l}\text { SRS } \\
\text { Northing } \\
\text { (fte) }\end{array}$ & $\begin{array}{l}\text { Bottom of } \\
\text { Screen } \\
\text { (msl) }\end{array}$ & $\begin{array}{l}\text { Topof } \\
\text { Screen } \\
\text { (msi) }\end{array}$ & $\begin{array}{l}\text { Median } \\
\text { Hydraulic } \\
\text { Head (ft) }\end{array}$ \\
\hline MSB 35D & 50949.70 & 102122.40 & 233.8 & 254.5 & 243.60 \\
\hline MSB 35TA & 50919.60 & 102101.60 & 32.9 & 38.2 & 199.80 \\
\hline MSB $36 A^{\circ}$ & 49514.90 & 100511.30 & 94.9 & 100.5 & 209.90 \\
\hline MSB 36 B & 49526.30 & 100514.90 & 158.1 & 163.7 & 214.20 \\
\hline MSB 36C & 49537.20 & 100518.30 & 188.6 & 194.2 & 214.25 \\
\hline MSB $36 \mathrm{D}$ & 49548.30 & 100521.70 & 228.8 & 249.5 & 238.00 \\
\hline MSB 36TA & 49503.00 & 100507.70 & 48.4 & 53.4 & 194.80 \\
\hline MSB' 38B & 49746.10 & 102360.80 & 141.8 & 146.5 & 215.25 \\
\hline MSB 38C & 49762.00 & 102373.10 & 164.3 & 169.0 & 218.00 \\
\hline MSB 38D & 49777.80 & 102385.60 & 220.9 & 240.4 & 234.25 \\
\hline MSB 38TA & 49810.40 & 102434.90 & 26.7 & 32.0 & 198.40 \\
\hline MSB 39A & 48367.30 & 100837.60 & 106.1 & 111.7 & 208.85 \\
\hline MSB 39B & 48376.90 & 100844.60 & 144.0 & 149.6 & 211.70 \\
\hline MSB 39C & 48386.70 & 100852.10 & 194.0 & 199.6 & 215.30 \\
\hline MSB 39D & 48396.00 & 100858.70 & 219.0 & 239.7 & 232.05 \\
\hline MSB 39TA & 48357.70 & 100830.60 & 44.4 & 49.7 & 192.90 \\
\hline MSB 40A & 48279.40 & 97672.80 & 110.6 & 116.2 & 203.30 \\
\hline MSB 40B & 48281.60 & 97685.00 & 149.1 & 154.7 & 205.00 \\
\hline MSB 40C & 48283.50 & 97697.80 & 186.8 & 192.4 & 205.00 \\
\hline MSB 40D & 48285.10 & 97709.30 & 216.2 & 236.8 & 227.90 \\
\hline MSB 40TA & 48277.20 & 97660.40 & 23.7 & 29.0 & 189.70 \\
\hline MSB 41A & 53424.10 & 102184.40 & 82.3 & 87.9 & 217.30 \\
\hline MSB 41B & 53417.80 & 102194.50 & 108.6 & 114.2 & 217.60 \\
\hline MSB $41 \mathrm{C}^{\prime}$ & 53410.60 & 102203.90 & 146.9 & 152.5 & 217.80 \\
\hline $\mathrm{MSB} 41 \mathrm{D}$ & 53403.70 & 102213.40 & 227.1 & 247.8 & 241.10 \\
\hline MSB 41TA & 53429.70 & 102176.50 & 21.4 & 26.7 & 206.40 \\
\hline MSB .49A & 45864.60 & 99759.00 & 72.0 & 76.7 & 197.50 \\
\hline MSB 49B & 45868.20 & 99737.80 & 110.7 & 116.3 & 203.60 \\
\hline MSB 49D & 45856.40 & 99724.90 & 216.7 & 236.4 & 229.65 \\
\hline MSB 50B & 51053.50 & 96433.00 & 149.6 & 155.2 & 202.50 \\
\hline MS̈B 500 & 51044.10 & 96416.70 & 190.8 & 210.9 & 202.85 \\
\hline MSB $51 B$ & 52818.00 & 96992.70 & 154.4 & 160.0 & 204.90 \\
\hline MSB 51D & 52816.20 & 97015.70 & 198.8 & 218.5 & 210.70 \\
\hline MSB 51DD & 52830.30 & 97006.20 & 215.8 & 235.4 & 212.20 \\
\hline MSB $57 \mathrm{D}$ & 48701.50 & 101829.50 & 210.1 & 229.6 & 231.40 \\
\hline MSB 58D & 48693.50 & 102200.60 & 211.1 & 230.5 & 231.00 \\
\hline MSB 59D & 48314.80 & 102182.20 & 209.9 & 229.3 & 229.90 \\
\hline MSB 60D & 48326.80 & 101835.50 & 208.9 & 228.3 & 230.20 \\
\hline MSB 62B & 47906.80 & 101865.30 & 136.3 & 141.0 & 208.20 \\
\hline MSB 62C & 47895.00 & 101857.20 & 185.2 & 190.0 & 223.05 \\
\hline MSB 62D & 47882.90 & 101849.00 & 212.4 & 231.9 & 229.10 \\
\hline MSB 63B & 47861.00 & 101184.40 & 136.2 & 140.9 & 208.90 \\
\hline MSB 63C & 47849.20 & 101174.60 & 191.1 & 195.8 & 220.40 \\
\hline MSB 63D & 47837.40 & 101165.20 & 212.8 & 232.8 & 229.50 \\
\hline MSB 64B & 46579.70 & 101831.00 & 119.6 & 124.3 & 207.75 \\
\hline MSB 64C & 46589.20 & 101842.90 & 176.5 & 181.2 & 222.65 \\
\hline
\end{tabular}


Capture Zone Analyses of Two Airlift Recirculation Wells

\begin{tabular}{|c|c|c|c|c|c|}
\hline Wêll Wo & $\begin{array}{r}\text { SRS Easting } \\
\text { (ftt) } \\
\end{array}$ & $\begin{array}{l}\text { SRS } \\
\text { Nonthing } \\
\text { (ft) }\end{array}$ & $\begin{array}{l}\text { Bottomofot } \\
\text { Screen } \\
\text { (msi) }\end{array}$ & $\begin{array}{l}\text { Top of } \\
\text { Screen } \\
\text { (msin) }\end{array}$ & $\begin{array}{r}\text { Median } \\
\text { Hydanulic } \\
\text { Head fot }\end{array}$ \\
\hline MSB $64 \mathrm{D}$ & 46598.50 & 101854.80 & 210.1 & 230.1 & 227.00 \\
\hline $\mathrm{MSB} 65 \overline{\mathrm{D}}$ & 49413.70 & 101915.50 & 224.4 & 243.9 & 233.55 \\
\hline MSB $70 \mathrm{C}$ & 45012.00 & 101785.20 & 174.1 & 178.8 & 217.90 \\
\hline $\mathrm{MSB}=2.2 \mathrm{~B}^{\prime}$ & 48350.30 & 96387.60 & 152.0 & 156.7 & 200.45 \\
\hline$\overline{\mathrm{ASB}} 73 \mathrm{~B}$ & 45694.00 & 99270.30 & 130.8 & 135.5 & 201.95 \\
\hline $\overrightarrow{\mathrm{MSB}} 7 \mathrm{4}$ & 50443.20 & 99197.40 & 142.8 & 147.5 & 211.20 \\
\hline MSB 74C & 50457.10 & 99191.10 & 173.1 & 177.8 & 211.00 \\
\hline MSB 74D & 50469.70 & 99185.30 & 217.1 & 237.1 & 232.95 \\
\hline MSB 75B & 48875.50 & 98937.40 & 156.9 & 161.7 & 209.95 \\
\hline MSB 75C & 48859.70 & 98942.30 & 188.8 & 193.5 & 209.85 \\
\hline MSB 79B & 47300.20 & 99296.90 & 136.1 & 140.8 & 207.80 \\
\hline MSB 79C & 47286.80 & 99290.20 & 194.9 & 199.6 & 210.05 \\
\hline MSB 87B & 51607.00 & 101276.00 & 169.1 & 174.1 & 219.20 \\
\hline MSB 87C & 51596.30 & 101277.00 & 241.6 & 246.6 & 243.90 \\
\hline MSB 88B & 50774.20 & 97013.00 & 70.8 & 75.8 & 201.80 \\
\hline MSB 88C & 50784.00 & 97012.70 & 122.2 & 127.2 & 204.30 \\
\hline MSB 88D & 50793.50 & 97012.30 & 192.1 & 212.2 & 205.30 \\
\hline MSB 89B & 47889.90 & 98374.10 & 157.0 & 162.0 & 207.80 \\
\hline MSB 89C & 47881.60 & 98379.40 & 217.6 & 222.6 & 229.70 \\
\hline
\end{tabular}

28 of 66 
Table 3. Adjusted Monitoring Well Hydraulic Head Measurements used to Generate Calibration Targets and Head Boundary Conditions

\begin{tabular}{|c|c|c|c|}
\hline Well & SRS Easting & $\begin{array}{c}\text { SRS Northing } \\
\text { (ft) }\end{array}$ & $\begin{array}{l}\text { Averaged } \\
\text { Hydraulic } \\
\text { Head(ft) }\end{array}$ \\
\hline $\mathrm{MCB} 6 \mathrm{C}$ & 45207.7 & 97413.1 & 196.10 \\
\hline$\overline{M C B} 12 \mathrm{~B} / \mathrm{C}^{-}$ & 45246.1 & 98326.2 & 199.30 \\
\hline $\mathrm{MSB} \overline{\mathrm{BC}}$ & 48538.5 & 102189.6 & 218.70 \\
\hline MSB $12 B$ & 47142.1 & 102272.8 & 217.95 \\
\hline $\mathrm{MSB} 14 \mathrm{~B}$ & 48519.1 & 101639.0 & 217.50 \\
\hline MSB $18 \mathrm{~A}$ & 46110.4 & 100416.1 & 212.50 \\
\hline MSB 19B & 50934.8 & 100999.3 & 217.00 \\
\hline MSB 32B & 52742.5 & 99676.0 & 211.90 \\
\hline MSB 33B & 51741.9 & 97995.9 & 207.85 \\
\hline $\mathrm{MSB} 35 \mathrm{~B}$ & 50947.9 & 102110.8 & 219.50 \\
\hline $\mathrm{MSB} 36 \mathrm{~B} / \mathrm{C}$ & 49526.3 & 100514.9 & 214.20 \\
\hline $\mathrm{MSB} 40 \mathrm{~B} / \mathrm{C}$ & 48281.6 & 97685.0 & 205.00 \\
\hline $\bar{M} S \bar{B} 41 \mathrm{C} / \mathrm{B}$ & 53410.6 & 102203.9 & 217.70 \\
\hline $\mathrm{MSB} 50 \mathrm{~B}$ & 51053.5 & 96433.0 & 202.50 \\
\hline $\mathrm{MSB} \mathbf{5 1 B}$ & 52818.0 & 96992.7 & 204.90 \\
\hline$M S B$ & 45012.0 & 101785.2 & 217.90 \\
\hline MSBB $72 \mathbf{B}$ & 48350.3 & 96387.6 & 200.45 \\
\hline$\overline{M S B} 73 \mathrm{~B}^{\prime}$ & 45694.0 & 99270.3 & 201.95 \\
\hline MSB $74 \overline{\mathrm{B}} / \mathrm{C}$ & 50443.2 & 99197.4 & 211.10 \\
\hline MSB 75BTC & 48875.5 & 98937.4 & 209.90 \\
\hline MSB $79 \overline{\mathrm{B}} / \mathrm{C}$ & 47300.2 & 99296.9 & 208.90 \\
\hline $\mathrm{MSB} 87 \mathrm{~B}^{2}$ & 51607.0 & 101276.0 & 219.20 \\
\hline $\mathrm{MSB} \times 8 \mathrm{CC} / \mathrm{B}$ & 50784.0 & 97012.7 & 203.10 \\
\hline MSB $89 \mathrm{~B}$ & 47889.9 & 98374.1 & 207.80 \\
\hline
\end{tabular}


Capture Zone Analyses of Two Airlift Recirculation Wells in the Southern Sector of $\mathrm{A} / \mathrm{M}$ Area

Page:

Table 4. Summary of Recirculation and Special Monitoring Well Coordinates

\begin{tabular}{|c|c|c|c|c|}
\hline Well W & $\begin{array}{l}\text { SRS Easting } \\
\text { (ft) }\end{array}$ & SRS Northing & $\begin{array}{l}\text { Bottom of } \\
\text { Screen (ms })\end{array}$ & $\begin{array}{l}\text { Top of Screen } \\
\text { (msl) }\end{array}$ \\
\hline \multicolumn{5}{|l|}{ Recirculation Wells } \\
\hline SSR-011B & 50111.0 & 98972.3 & 147.6 & 157.2 \\
\hline SSR $01 \mathrm{IC}$ & 50111.0 & 98972.3 & 170.6 & 180.2 \\
\hline SSR-012B & 50301.0 & 99142.6 & 143.6 & 153.2 \\
\hline SSR $012 \mathrm{C}$ & 50301.0 & 99142.6 & 177.0 & 186.5 \\
\hline \multicolumn{5}{|l|}{ Monitoring Wells } \\
\hline SSM-001 $\tilde{B}$ & 48240.0 & 97301.8 & 143.5 & 148.5 \\
\hline SSM-001C & 48240.0 & 97301.8 & 178.5 & 183.5 \\
\hline SSM-002B & 48239.8 & 97252.3 & 144.0 & 149.0 \\
\hline SSM-002C & 48250.0 & 97252.6 & 179.2 & 184.2 \\
\hline SSM-003B & 50298.1 & 99161.7 & 142.8 & 147.8 \\
\hline SSM-003C & 50308.2 & 99160.9 & 173.6 & 178.6 \\
\hline SSM-004B & 50298.0 & 99121.0 & 141.7 & 146.7 \\
\hline SSM-004C & 50308.4 & 99122.2 & 172.8 & 177.8 \\
\hline SSM-005B & 50378.1 & 99164.6 & 139.6 & 144.6 \\
\hline SSM-005C & 50374.6 & 99173.4 & 169.6 & 174.6 \\
\hline SSM-006B & 50416.6 & 99179.3 & 141.7 & 146.7 \\
\hline SSM-006C & 50412.6 & 99186.8 & 171.6 & 176.6 \\
\hline SSM-007B & 50481.2 & 99203.7 & 144.0 & 149.0 \\
\hline SSM-007C & 50477.4 & 99213.3 & 174.1 & 179.1 \\
\hline SSM $008 \mathrm{~B}$ & 50154.7 & 99003.5 & 152.7 & 157.7 \\
\hline SSM $008 \mathrm{E}$ & 50148.4 & 99011.7 & 178.1 & 183.1 \\
\hline SSM $-009 \mathrm{~B}$ & 50167.2 & 99028.6 & 151.7 & 156.7 \\
\hline SSM:009 & 50173.2 & 99020.0 & 177.3 & 182.5 \\
\hline
\end{tabular}

Table 5. Summary of Pumping Well Tests in AM Southern Sector

\begin{tabular}{|c|c|c|c|c|c|c|}
\hline Well & $\begin{array}{l}\text { SRSEASting } \\
\quad \text { (ft) }\end{array}$ & SRSNofthing & $\begin{array}{r}\mathrm{K}+\mathrm{BE} \\
(\mathbf{f}) \mathrm{d})\end{array}$ & $\begin{array}{l}\mathrm{K} / \mathrm{GB} \\
(\mathrm{ft} / \mathrm{d}) \mathrm{F}\end{array}$ & $\begin{array}{c}\mathrm{K}_{\mathrm{H}}^{\mathrm{T}}-\mathrm{UBB}^{2} \\
\text { (ft/d) }\end{array}$ & $\begin{array}{r}\mathrm{K}-\mathrm{BE} \\
(\mathrm{ft} / \mathrm{d})\end{array}$ \\
\hline \multicolumn{7}{|c|}{ WSRCTR 92,529} \\
\hline RWMAOPA & 48364.9 & 97783.9 & 33.4 & 29.5 & 36.6 & $\overline{\text { na }}$ \\
\hline RWMíPB & 48212.5 & 97672.1 & 31.1 & 29.6 & 35.5 & na \\
\hline MSB $40 \mathrm{~B}$ & 48281.6 & 97685.0 & 29.3 & 22.4 & 34.3 & na \\
\hline \multicolumn{7}{|c|}{ WSR CETR 95-0365 } \\
\hline MSB32B & 52742.5 & 99676.0 & 119.1 & na & na & na \\
\hline $\mathrm{MSB32B}$ & 52742.5 & 99676.0 & 119.1 & na & na & na \\
\hline $\mathrm{MSB32C}$ & 52746.9 & 99684.9 & 57.6 & na & na & na \\
\hline $\mathrm{MSB} 88 \mathrm{C}$ & 50784.0 & 97012.7 & 66.7 & na & na & na \\
\hline MSB89B & 47889.9 & 98374.1 & 21.0 & na & na & na \\
\hline MSB $89 \mathrm{C}$ & 47881.6 & 98379.4 & 52.7 & na & na & na \\
\hline \multicolumn{7}{|c|}{ WSRC-TR-98-00428 } \\
\hline SSR012 & 50301.0 & 99142.6 & 25.8 & na & na & 1.43 \\
\hline
\end{tabular}


Table 6. List of Observation Wells

\begin{tabular}{|c|c|c|c|c|c|c|c|}
\hline Well ID & $\begin{array}{r}\text { SRS } \\
\text { Easting } \\
\text { (ft) }\end{array}$ & $\begin{array}{l}\text { SRS } \\
\text { Northing } \\
\text { (ft) }\end{array}$ & $\begin{array}{l}\mathbf{B O S} \mathbf{S}^{1} \\
(\mathbf{f t})\end{array}$ & $\begin{array}{l}\mathrm{TOS} \mathbf{S}^{2-} \\
(\mathrm{ft})\end{array}$ & $\begin{array}{c}1990-9^{3} \\
\mathrm{Avg} \\
(\mathrm{ft})\end{array}$ & $\begin{array}{l}\mathbf{F A C T ^ { 4 }} \\
\text { (ft) }\end{array}$ & $\begin{array}{l}\text { Head } \\
\text { Residual } \\
\text { (ft) }\end{array}$ \\
\hline \multicolumn{8}{|l|}{ Group 1} \\
\hline MSB 36B & 49526.30 & 100514.90 & 158.1 & 163.7 & 214.20 & 214.2 & 0.0 \\
\hline $\mathrm{MSB} 36 \mathrm{C}$ & 49537.20 & 100518.30 & 188.6 & 194.2 & 214.25 & 214.3 & 0.0 \\
\hline MSB $74 B$ & 50443.20 & 99197.40 & 142.8 & 147.5 & 211.20 & 210.8 & -0.4 \\
\hline MSB & 50457.10 & 99191.10 & 173.1 & 177.8 & 211.00 & 210.8 & -0.2 \\
\hline MSB 75B & 48875.50 & 98937.40 & 156.9 & 161.7 & 209.95 & 209.8 & -0.1 \\
\hline
\end{tabular}

\section{Bottom of Screen elevation}

2 Top of Screen elevation

3 EMS quarterly hydraulic head well measurements taken over the period 1990 to 1999 were sorted to determine the median value

4 FACT computed screen averaged hydraulic head

Table 7. Nomenclature and Parameter Settings for the Flow Simulations

\begin{tabular}{|c|c|c|c|c|c|}
\hline Case Identifiex & $\left(\begin{array}{l}K_{h} \\
(t / d)\end{array}\right.$ & $\begin{array}{l}\mathrm{K}_{\mathrm{V}} \\
(\mathrm{ft} / \mathrm{d}) \\
\end{array}$ & 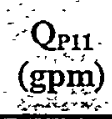 & $\underset{(\mathrm{Qpm})}{(\mathrm{gpm})}$ & $\phi$ \\
\hline Base Case & 25.8 & 1.43 & 0.0 & 0.0 & 0.2 \\
\hline Nominal-A & 25.8 & 1.43 & 43.0 & 43.0 & 0.2 \\
\hline Nómiñal $\mathrm{B}$ & 25.8 & 1.43 & 43.0 & 0.0 & 0.2 \\
\hline Nominallec & 25.8 & 1.43 & 0.0 & 43.0 & 0.2 \\
\hline Sensitivity-A & 57.6 & 1.43 & 43.0 & 43.0 & 0.2 \\
\hline Sensitivity $\mathrm{B}$ & 21.0 & 1.43 & 43.0 & 43.0 & 0.2 \\
\hline Sensitivity-C & 25.8 & 2.145 & 43.0 & 43.0 & 0.2 \\
\hline Sensitivity $=$ & 25.8 & 0.715 & 43.0 & 43.0 & 0.2 \\
\hline Sensitivity $\mathrm{E}^{-}$ & 25.8 & 1.43 & 60.0 & 43.0 & 0.2 \\
\hline Sensitivity -F" & 25.8 & 1.43 & 20.0 & 43.0 & 0.2 \\
\hline Sensitivity & 25.8 & 1.43 & 43.0 & 60.0 & 0.2 \\
\hline Señsitivity & 25.8 & 1.43 & 43.0 & 20.0 & 0.2 \\
\hline Sensitivity $=$ & 25.8 & 1.43 & 43.0 & 43.0 & 0.25 \\
\hline Sensitivity $=$ & 25.8 & 1.43 & 43.0 & 43.0 & 0.15 \\
\hline
\end{tabular}


Table 8. Summary of Key Flow Results for Nominal and Sensitivity Runs

\begin{tabular}{|c|c|c|c|c|c|c|c|}
\hline $\begin{array}{c}\text { Case } \\
\text { Identifier }\end{array}$ & $\begin{array}{l}\text { Parameter } \\
\text { Settings } \\
\end{array}$ & $\begin{array}{r}\mathrm{Qw}_{\mathrm{w}} \\
\therefore(\mathrm{gpm})\end{array}$ & $\begin{array}{l}\text { Capture } \\
\text { Zone } \\
\text { Width } \\
\text { (ft) }\end{array}$ & $\begin{array}{r}\mathbf{V}_{\mathbf{R}} \\
\left(\mathrm{ft}^{3}\right)\end{array}$ & $\begin{array}{c}Q_{a} \\
(\text { gpmm) }\end{array}$ & $\begin{array}{l}Q_{\mathrm{R}} \\
(\mathrm{gpm}) \\
\end{array}$ & $\begin{array}{l}\text { Percent } \\
\text { Recycle } \\
(\%) \\
\text { (\%) }\end{array}$ \\
\hline Bàse Case & baseline & 0.0 & 0.0 & 0.0 & na & na & na \\
\hline Nominal-A & nominals & 86.0 & 684 & 12964834 & 16.4 & 69.4 & 81 \\
\hline Nomininầ-B & nominals & 43.0 & 454 & 4340222 & 10.7 & 23.3 & 54 \\
\hline Nominal-C & nominals & 43.0 & 485 & 6021172 & 11.9 & 22.1 & 51 \\
\hline Sensitivity-A & $\mathrm{K}_{\mathrm{h}}-$ upper & 86.0 & 725 & 14040975 & 17.3 & 68.7 & 80 \\
\hline Sensitivity-B & $K_{h}$ - lower & 86.0 & 661 & 11817062 & 15.9 & 70.1 & 82 \\
\hline Sensitivity-C & $\mathrm{K}_{\mathrm{v}}$ - upper & 86.0 & 610 & 10898904 & 15.2 & 70.8 & 82 \\
\hline Sensitivity-D & $\mathrm{K}_{\mathrm{v}}$ - lower & 86.0 & 825 & 15375135 & 20.5 & 65.5 & 76 \\
\hline Sensitivity-E & $Q_{P 11}$ - upper & 103.0 & 684 & 14040975 & 16.4 & 86.6 & 84 \\
\hline Sensitivity-F & $\mathrm{Q}_{\mathrm{P} 11}$ - lower & 63.0 & 639 & 11142792 & 15.4 & 47.6 & 76 \\
\hline Sensitivity-G & $\mathrm{Q}_{\mathrm{P} 12}$ - upper & 103.0 & 702 & 14247648 & 17.3 & 85.7 & 83 \\
\hline Sensitivity-H & $\mathrm{Q}_{\mathrm{P} 2}$ - lower & 63.0 & 616 & 14046501 & 15.0 & 48.0 & 76 \\
\hline Sensitivity-I & $\phi$ - upper & 86.0 & 674 & 12964834 & 20.5 & 65.5 & 76 \\
\hline Sensitivity-J & $\phi$ - lower & 86.0 & 674 & 12964834 & 12.3 & 73.7 & 86 \\
\hline Meañ Value & - & 86 & 693 & 13003797 & 16.9 & 69.1 & 80.4 \\
\hline $\begin{array}{l}\text { Standard } \\
\text { Deviation }\end{array}$ & - & 0 & 67 & 1445825 & 2.9 & 2.9 & 3.6 \\
\hline
\end{tabular}




\section{FIGURES}




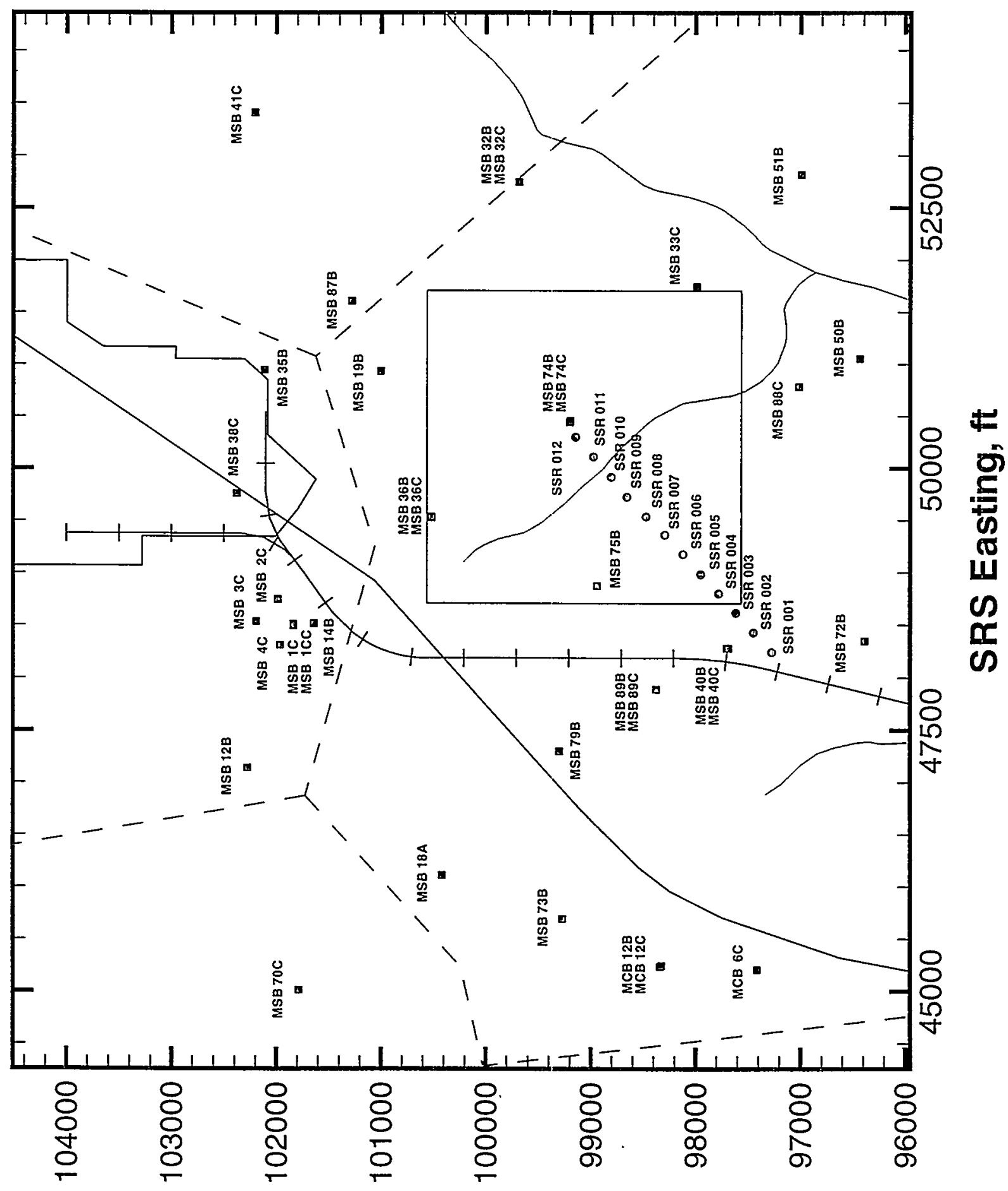

\section{H ‘bu!nuION Sys}

Figure 1. Plan View of the Basemap for Southern Sector in the $A / M$ Area 


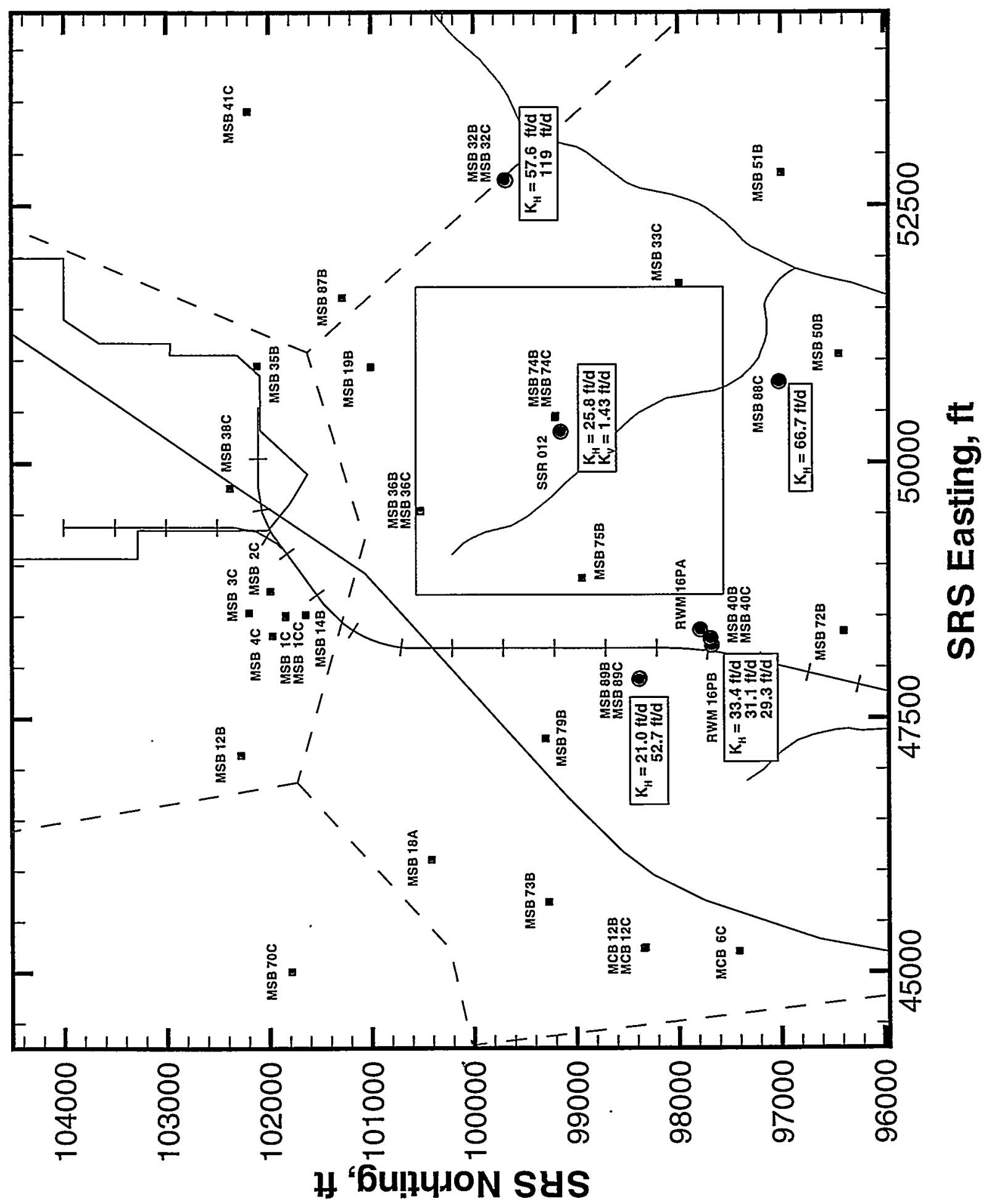

Figure 2. Plan View of the Basemap Highlighting Locations of Pumping Well Tests 
WESTINGHOUSE SAVANNAH RIVER COMPANY

Capture Zone Analyses of Two Airlift Recirculation Wells in the Southern Sector of $\mathrm{A} / \mathrm{M}$ Area
Report:

Revision:

Date:

Page:
WSRC-TR-99-00203

$6 / 99$

36 of 66

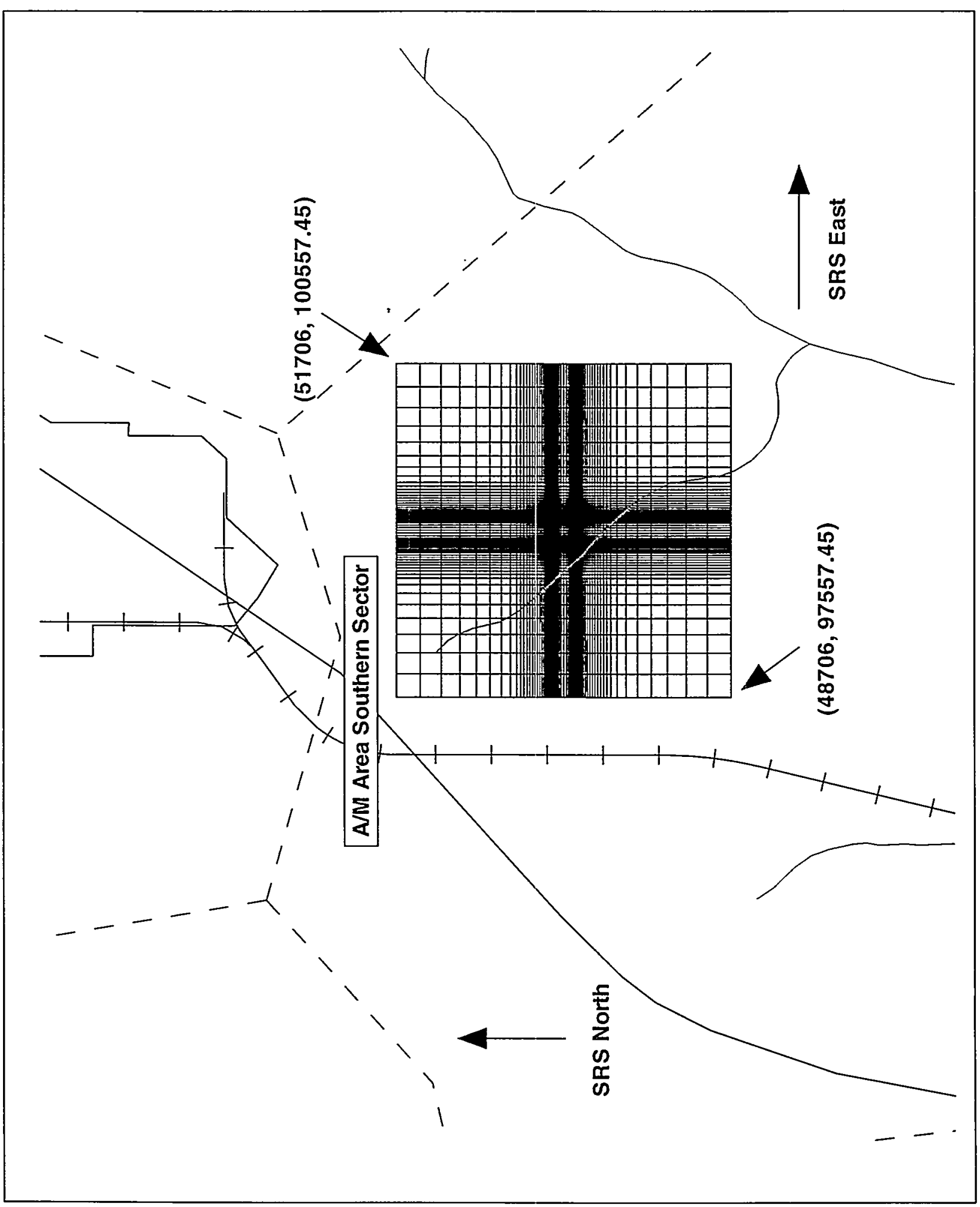

Figure 3. Layout of Areal Grid for the FACT Flow and Transport Model 


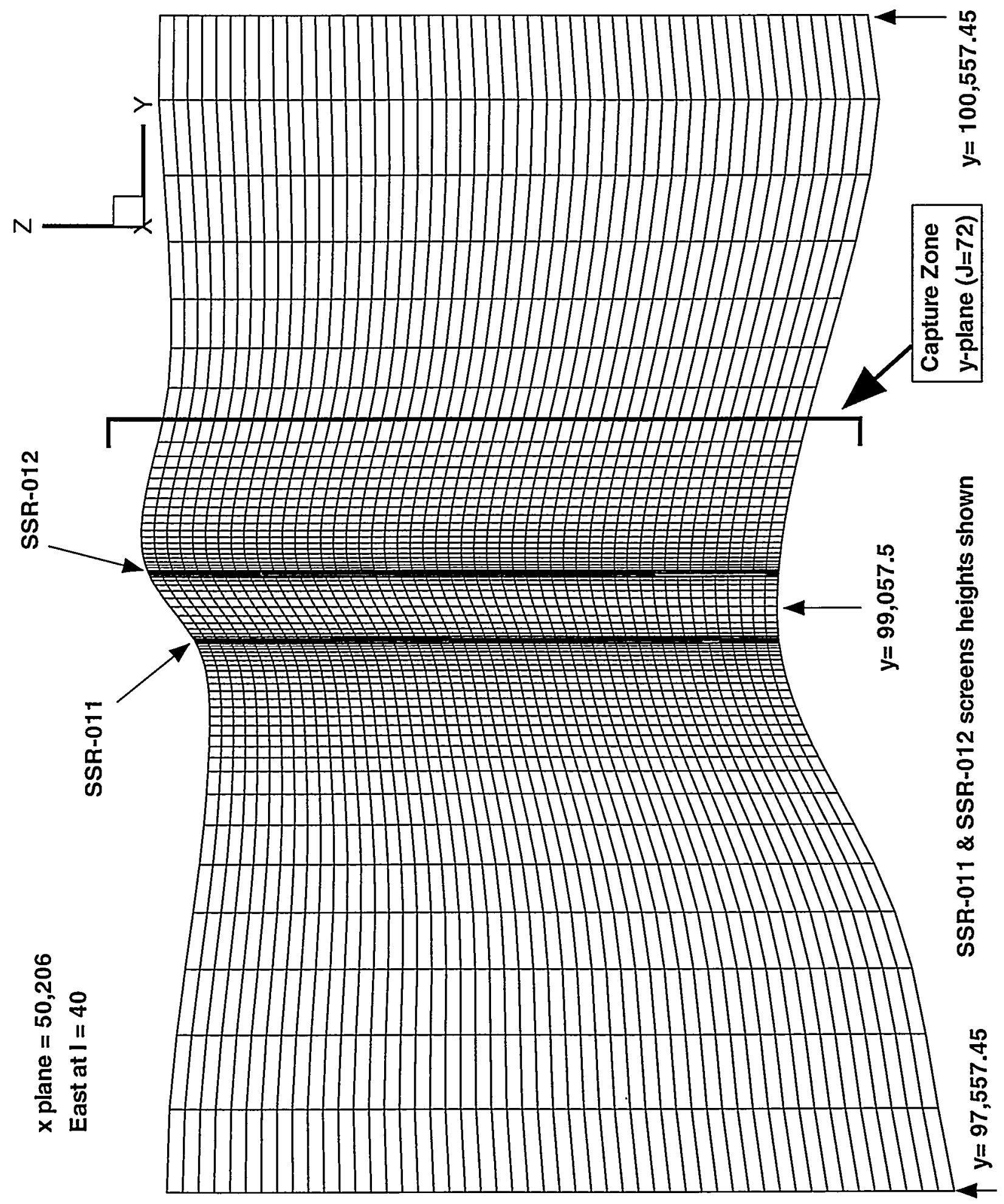

Figure 4. A Vertical Grid Slice (a x-plane) Through the Center of the Model Domain 
Date:

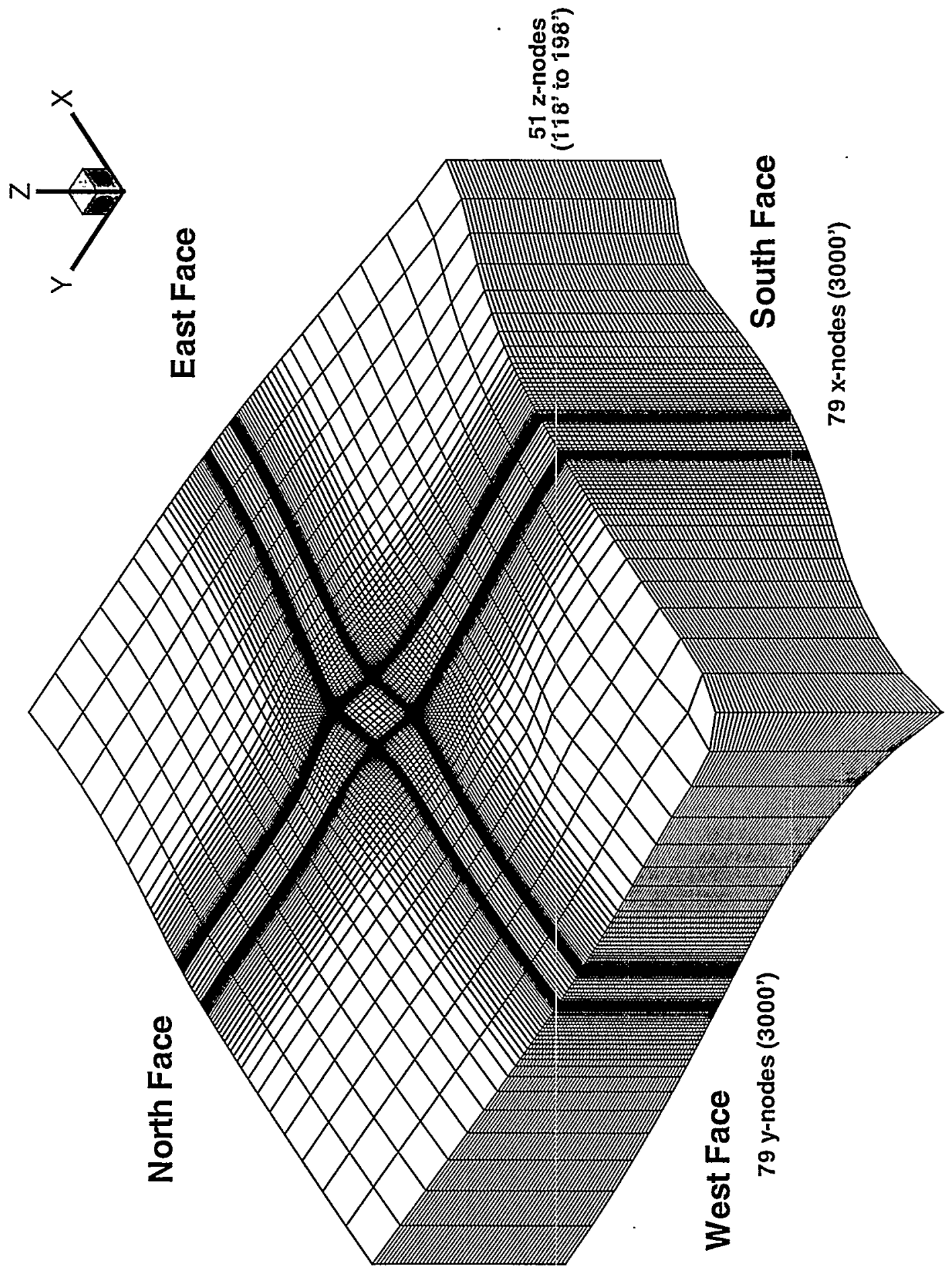

Figure 5. Three-Dimensional Mesh and Material Zone 
Capture Zone Analyses of Two Airlift Recirculation Wells

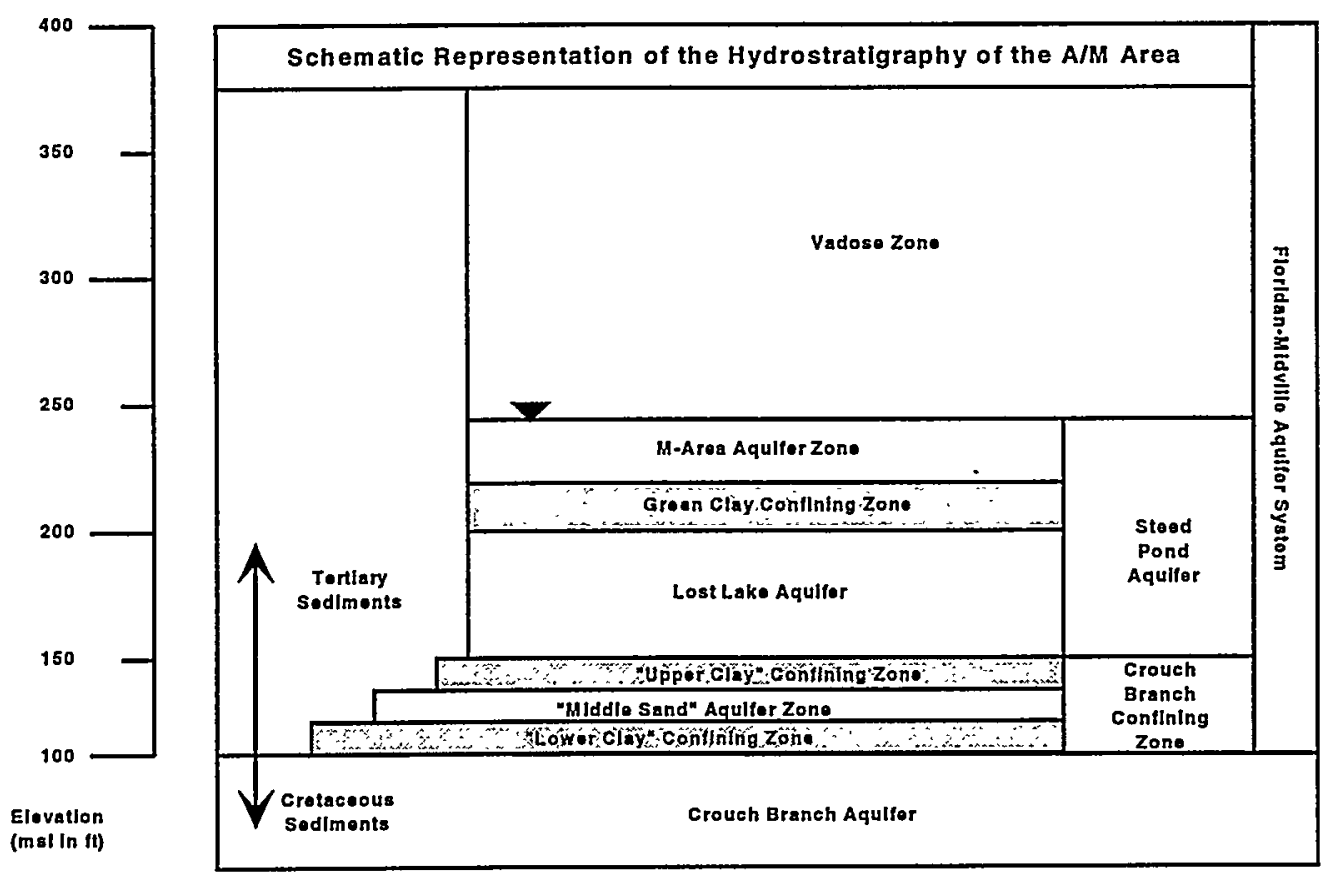

Figure 6. Hydrostratigraphic Nomenclature of the Southeaster Coastal Plain for the A/M Area 


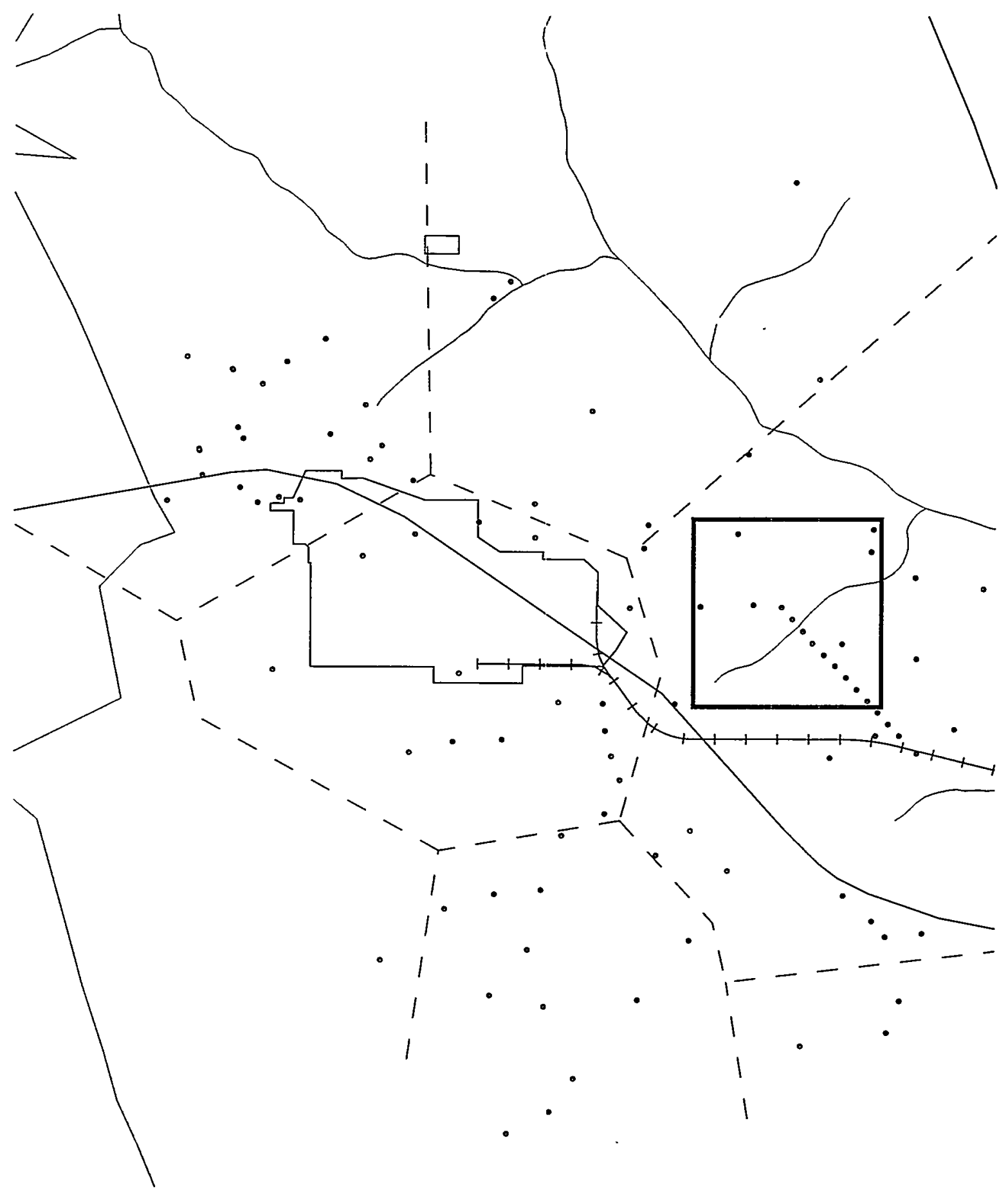

Figure 7. Hydrostratigraphic "Picks" of the Lost Lake Aquifer Zone 


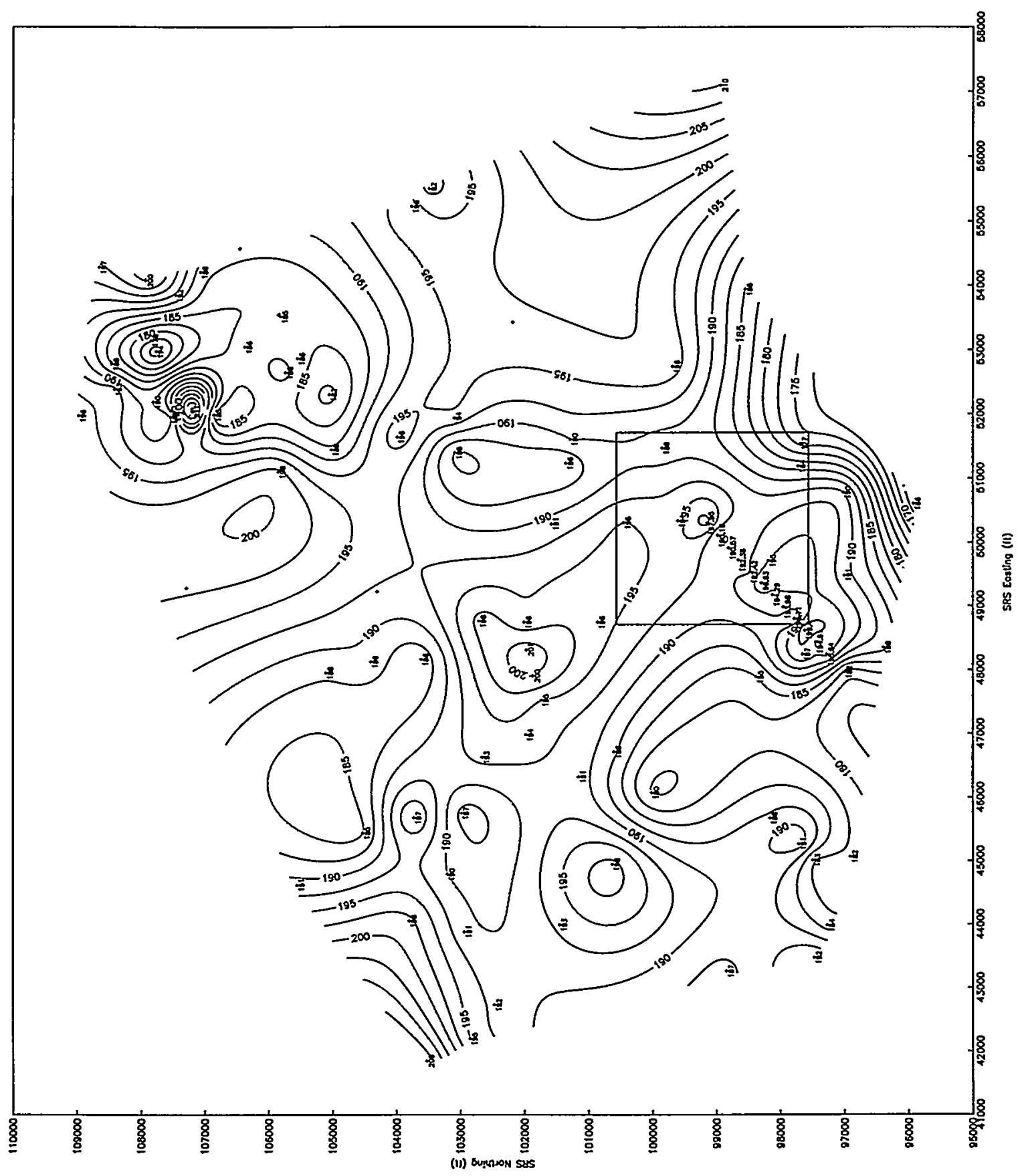

Figure 8. Altitude Contour Map of the Top of the "Lost Lake" Aquifer Zone 


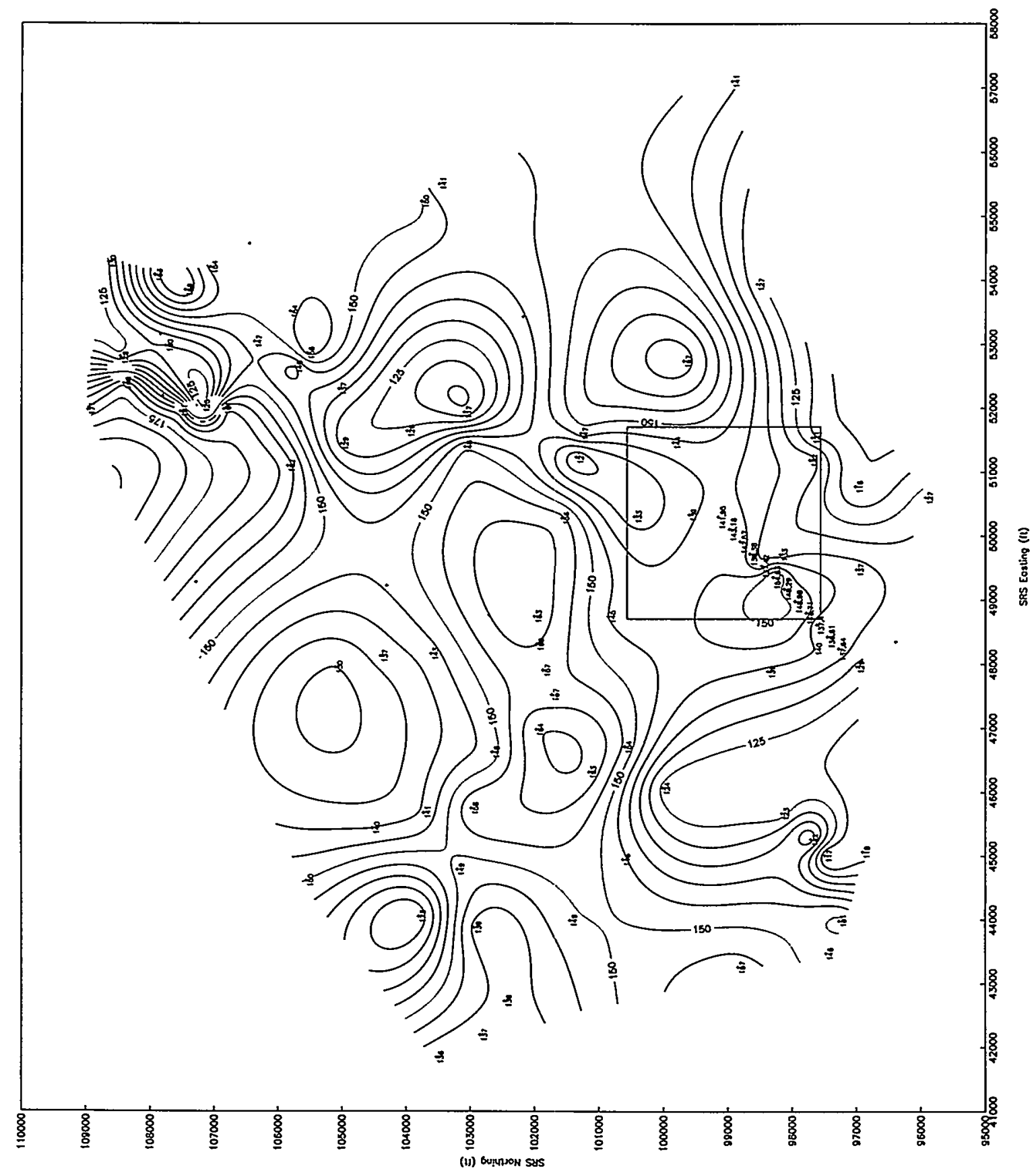

Figure 9. Altitude Contour Map of the Top of the "Upper" Interval of the Crouch Branch Confining Unit/Base of the "Lost Lake" Aquifer Zone 
WESTINGHOUSE SAVANNAH RIVER COMPANY

Capture Zone Analyses of Two Airlift Recirculation Wells in the Southern Sector of $\mathrm{A} / \mathrm{M}$ Area
Report: WSRC-TR-99-00203 Revision:

Date:

Page:

$\begin{array}{r}0 \\ 6 / 99 \\ 43 \text { of } 66 \\ \hline\end{array}$

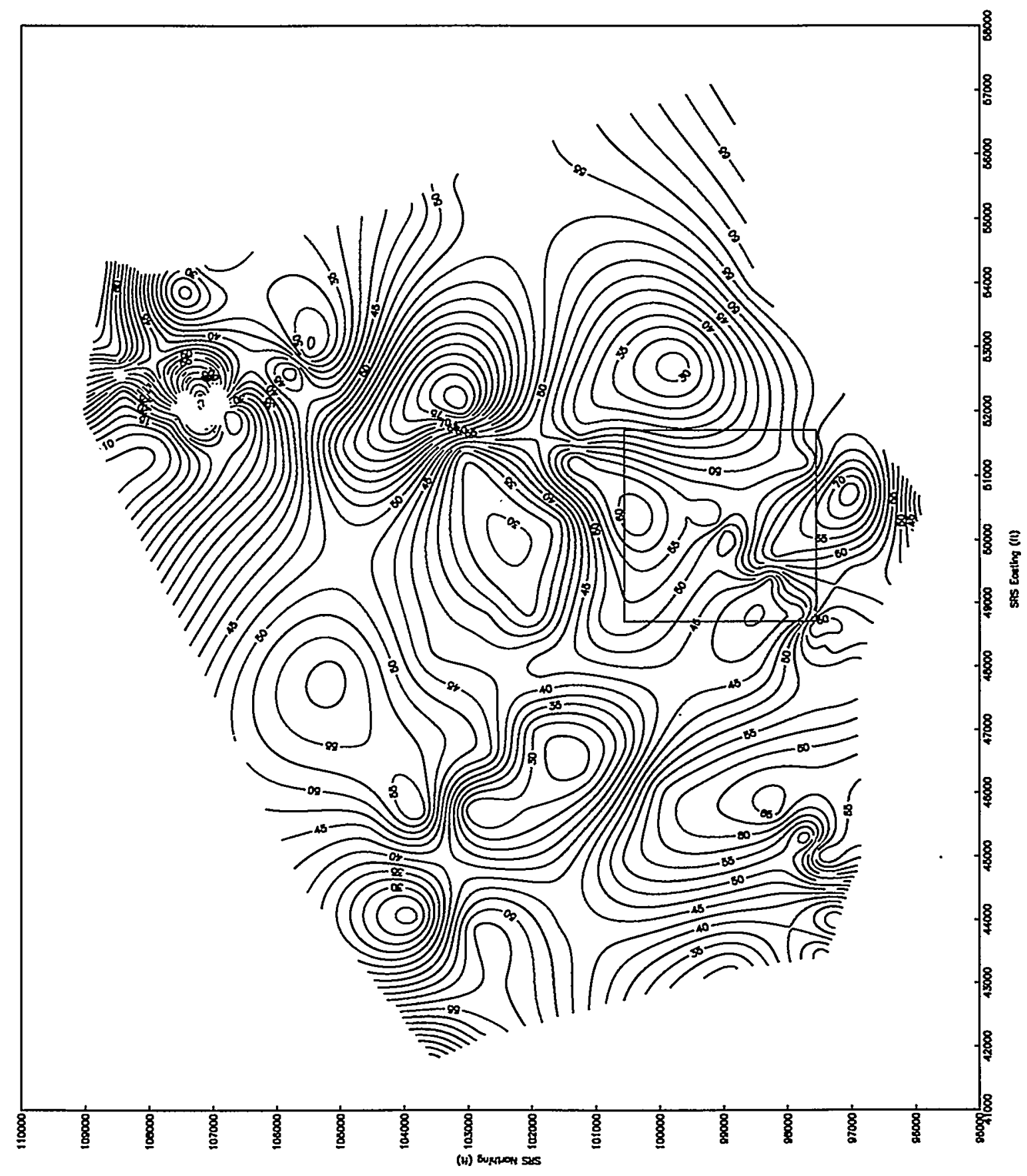

Figure 10. Isopach Map of the "Lost Lake" Aquifer Zone 
WESTINGHOUSE SAVANNAH RIVER COMPANY

Capture Zone Analyses of Two Airlift Recirculation Wells in the Southern Sector of $A / M$ Area
Report:

Revision:

Date:

Page:
WSRC-TR-99-00203

0 $6 / 99$ 44 of 66

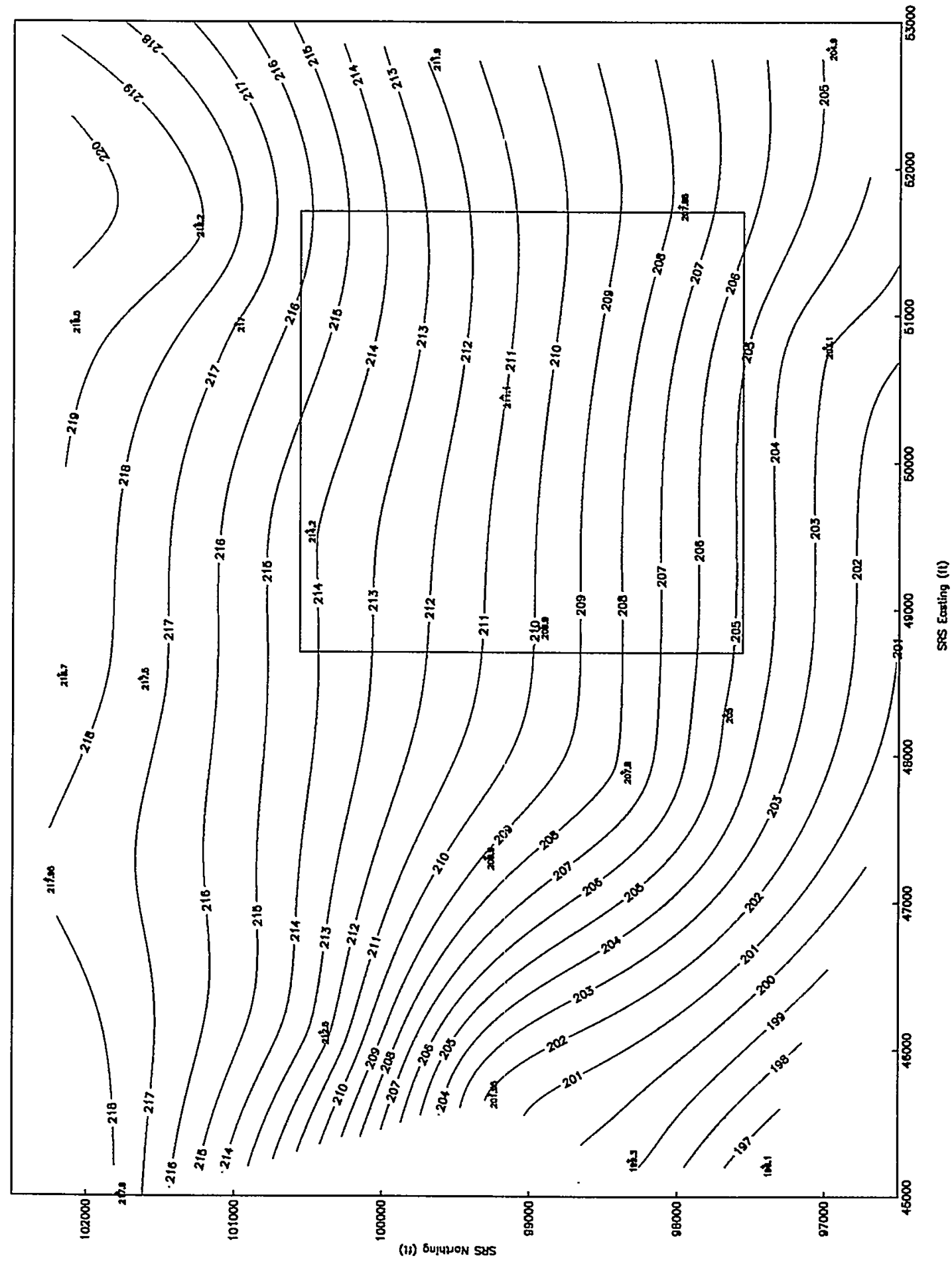

Figure 11. Potentiometric Map of the Lost Lake Aquifer Zone 


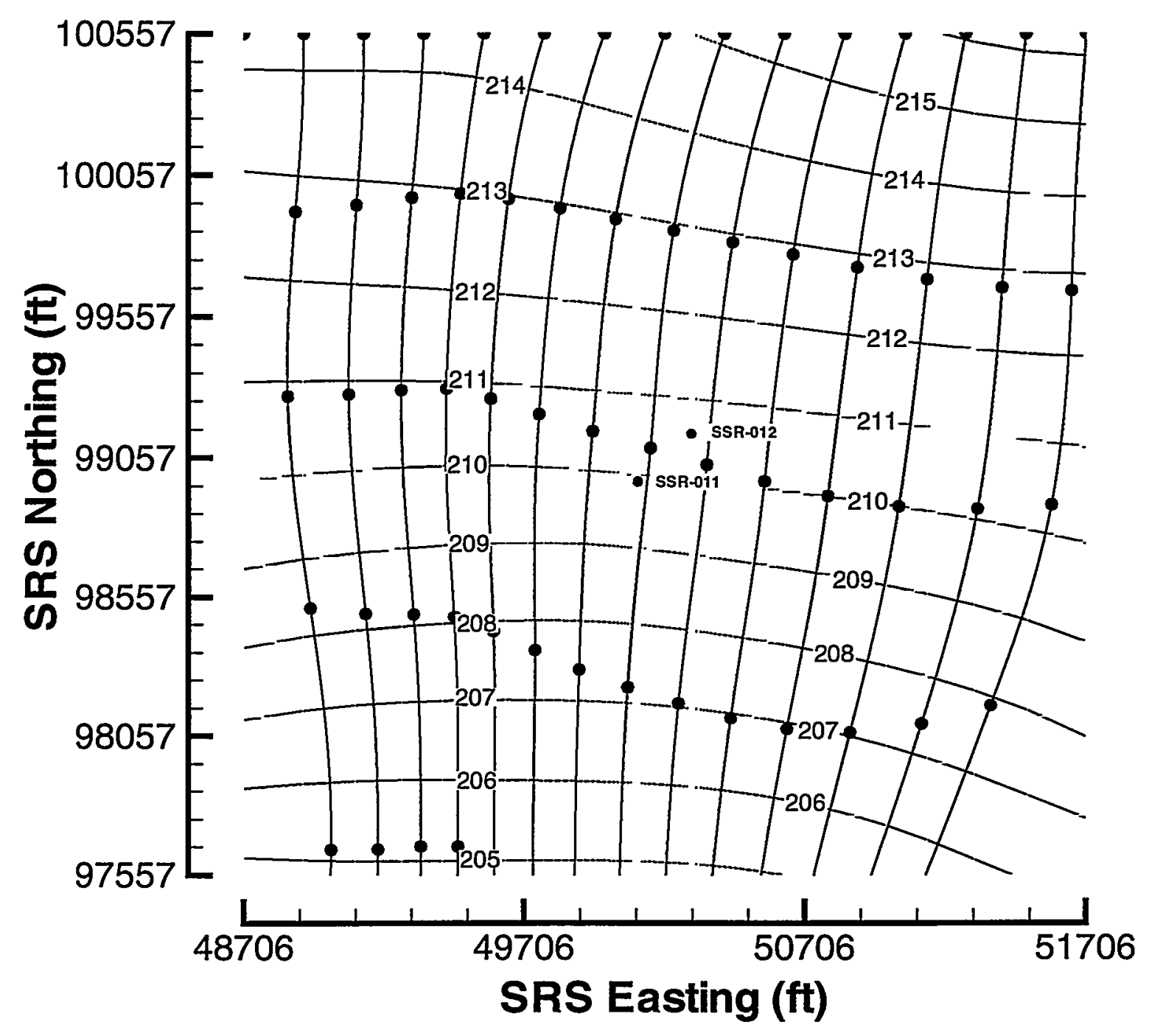

Figure 12. Computed Potentiometric Map with 5-year Timing Markers (Base Case) 


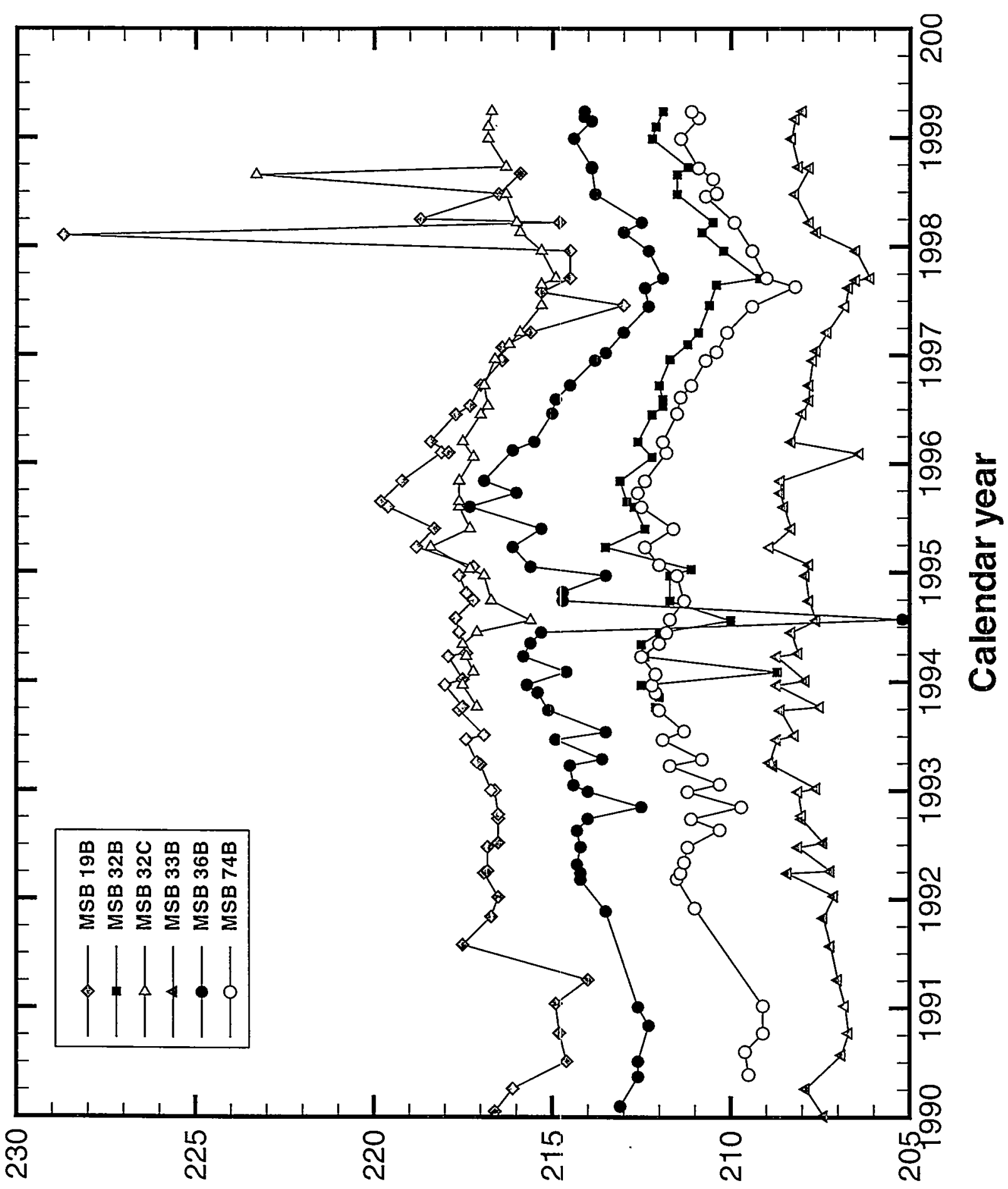

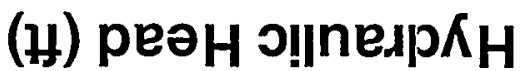

Figure 13. Measured Hydraulic Heads for Several Monitoring Wells Near The Model Domain 


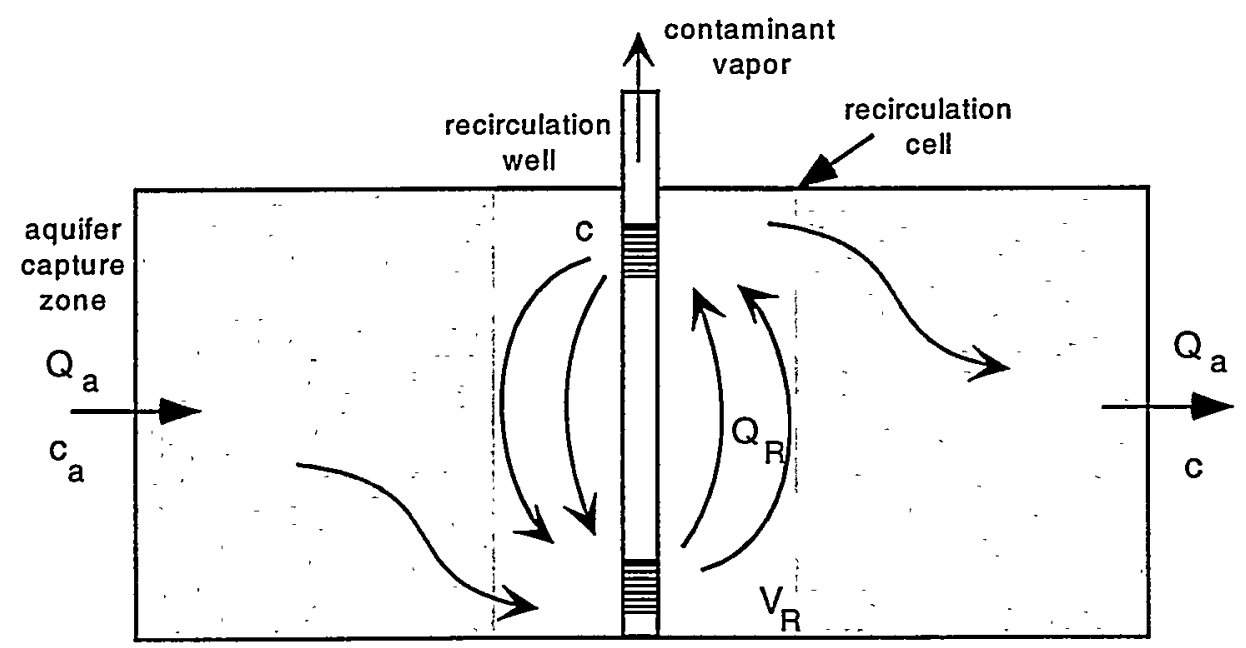

(a)

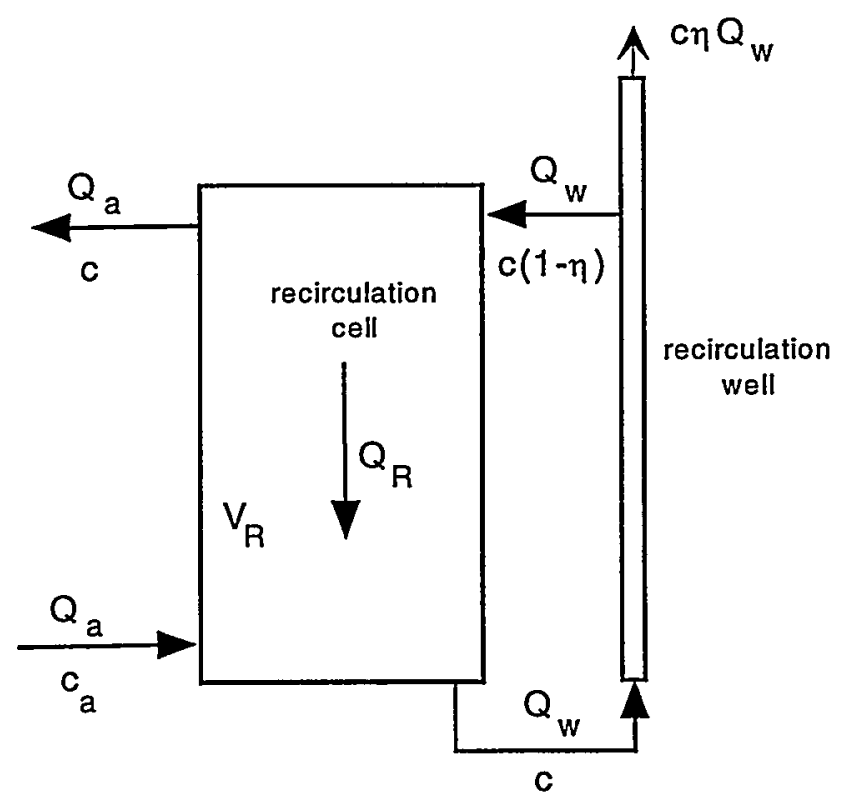

(b)

Figure 14. Schematic of Basic Flow Pattern Under Vertical Recirculation Well Operation and CSTR Model 


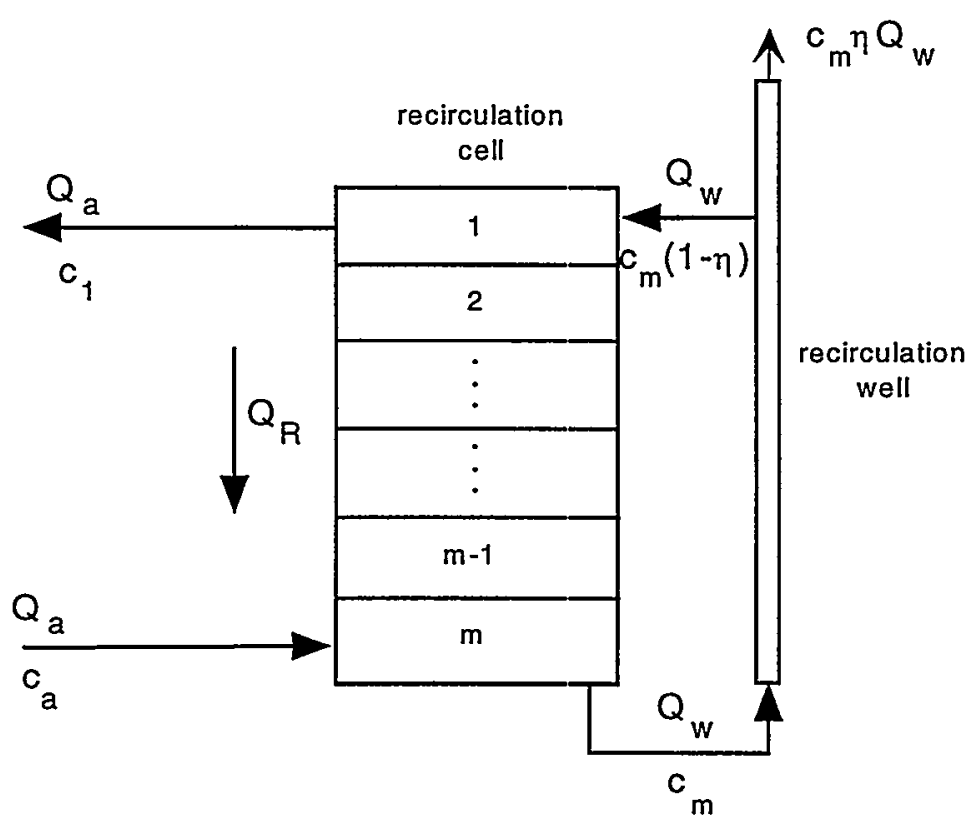

Figure 15. Schematic of Plug Flow Model for Vertical Recirculation Well Operation 


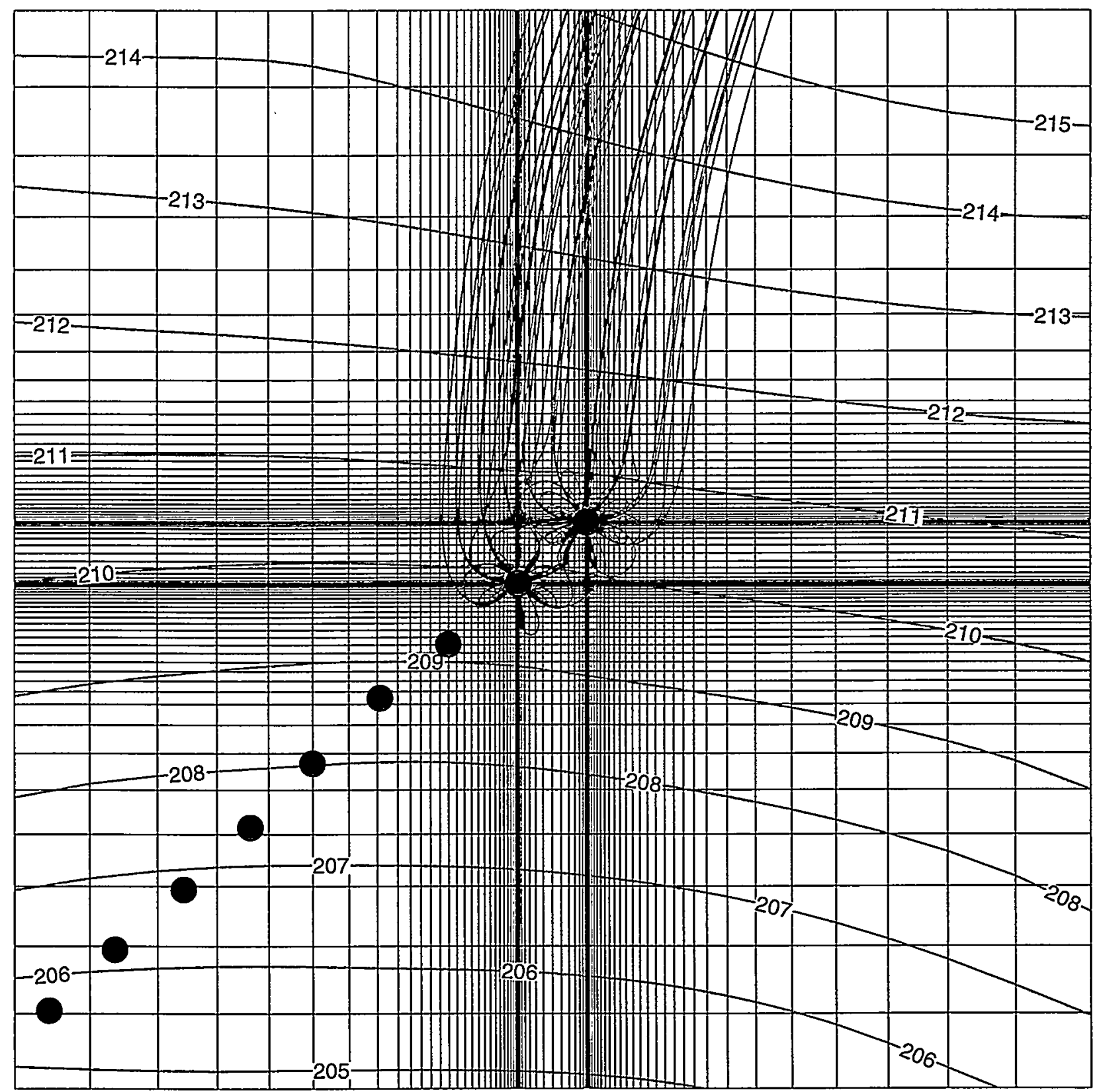

Figure 16. XY Projection of Capture Zone for SSR-011 and SSR-012 (Nominal-A) 


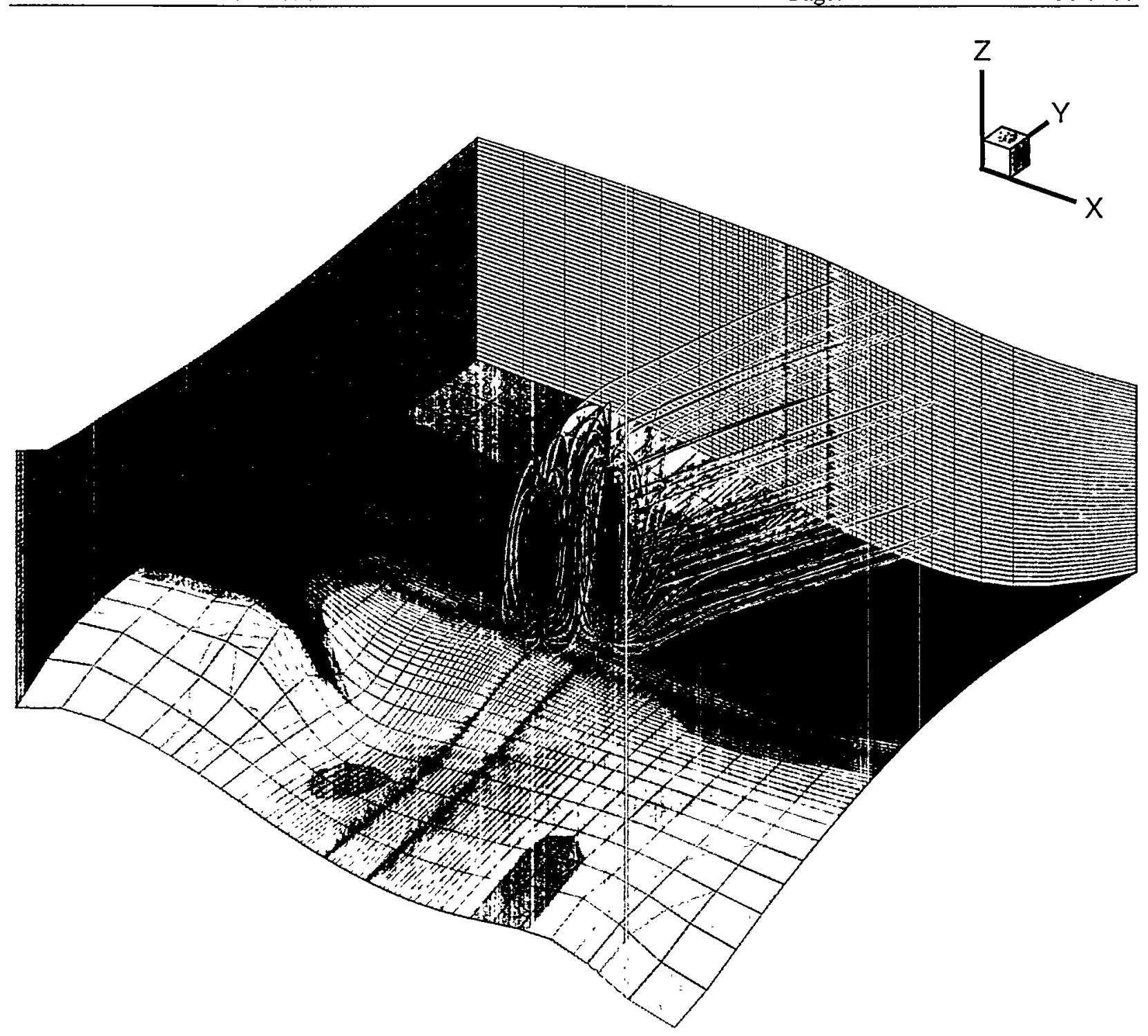

Figure 17. 3D Streamtraces of Capture Zone for SSR-011 and SSR-012 (Nominal-A) 


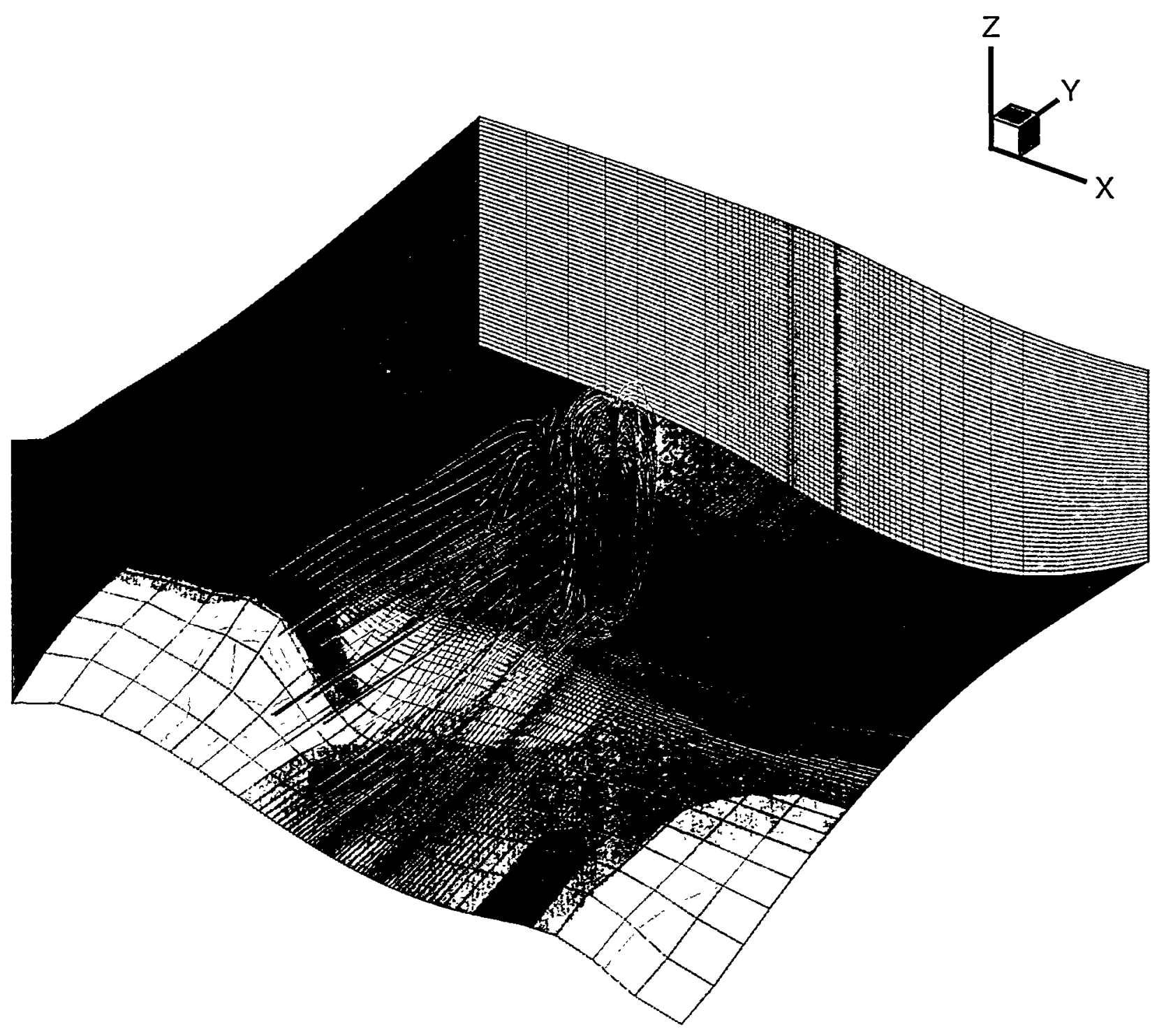

Figure 18. 3D Streamtraces of Rejection Zone for SSR-011 and SSR-012 (Nominal-A) 
WESTINGHOUSE SAVANNAH RIVER COMPANY

Capture Zone Analyses of Two Airlift Recirculation Wells in the Southern Sector of $A / M$ Area
Report: WSRC-TR-99-00203 Revision: $\quad 0$

Date: $\quad 6 / 99$

52 of 66

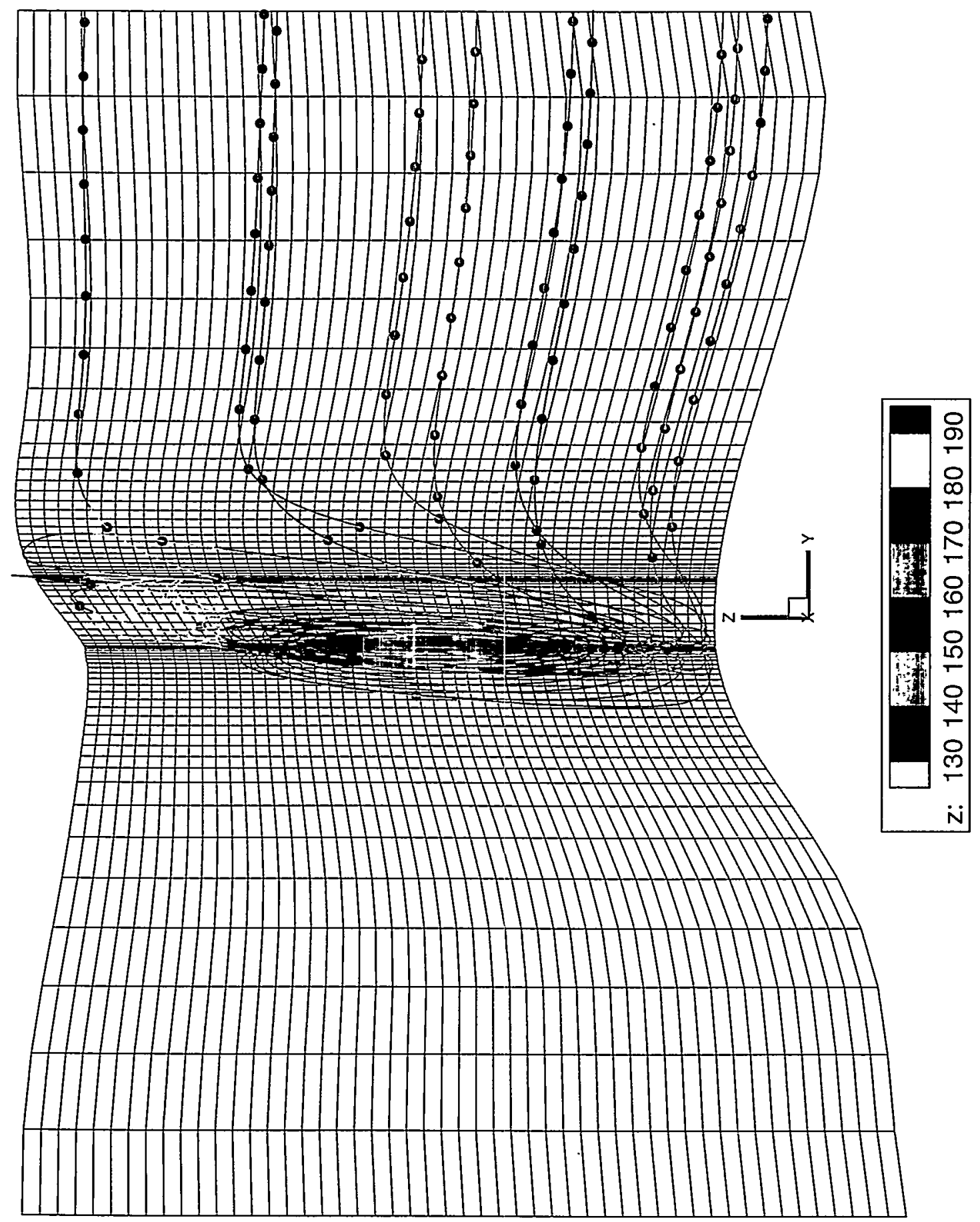

Figure 19. YZ Projection of Capture Zone for SSR-011 with 1-year Timing Markers (Nominal-A) 
WESTINGHOUSE SAVANNAH RIVER COMPANY

Capture Zone Analyses of Two Airlift Recirculation Wells in the Southern Sector of A/M Area
Report: WSRC-TR-99-00203

Revision: $\quad 0$

Date: $\quad 6 / 99$

Page:

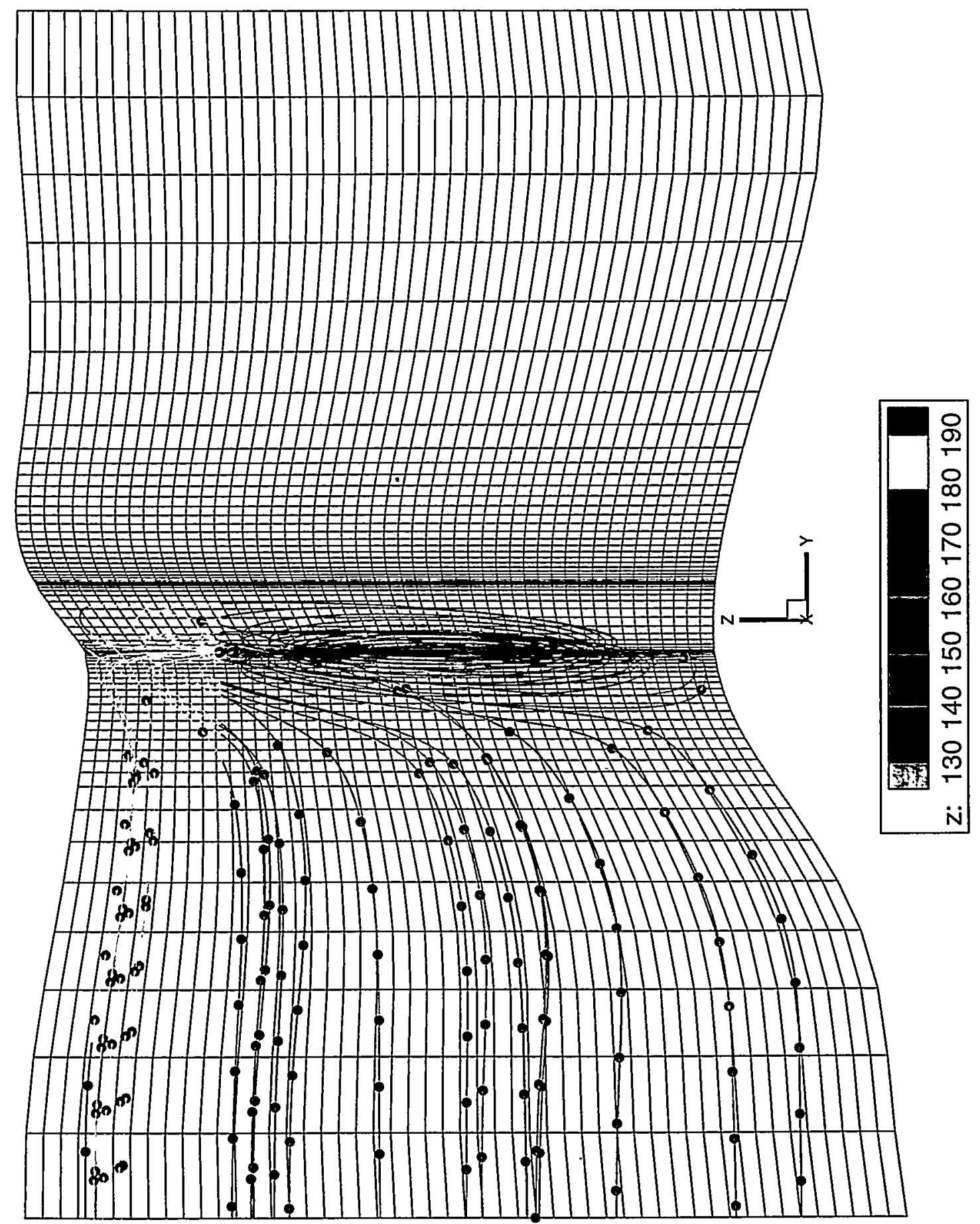

Figure 20. YZ Projection of Rejection Zone for SSR-011 with 1-year Timing Markers (Nominal-A) 


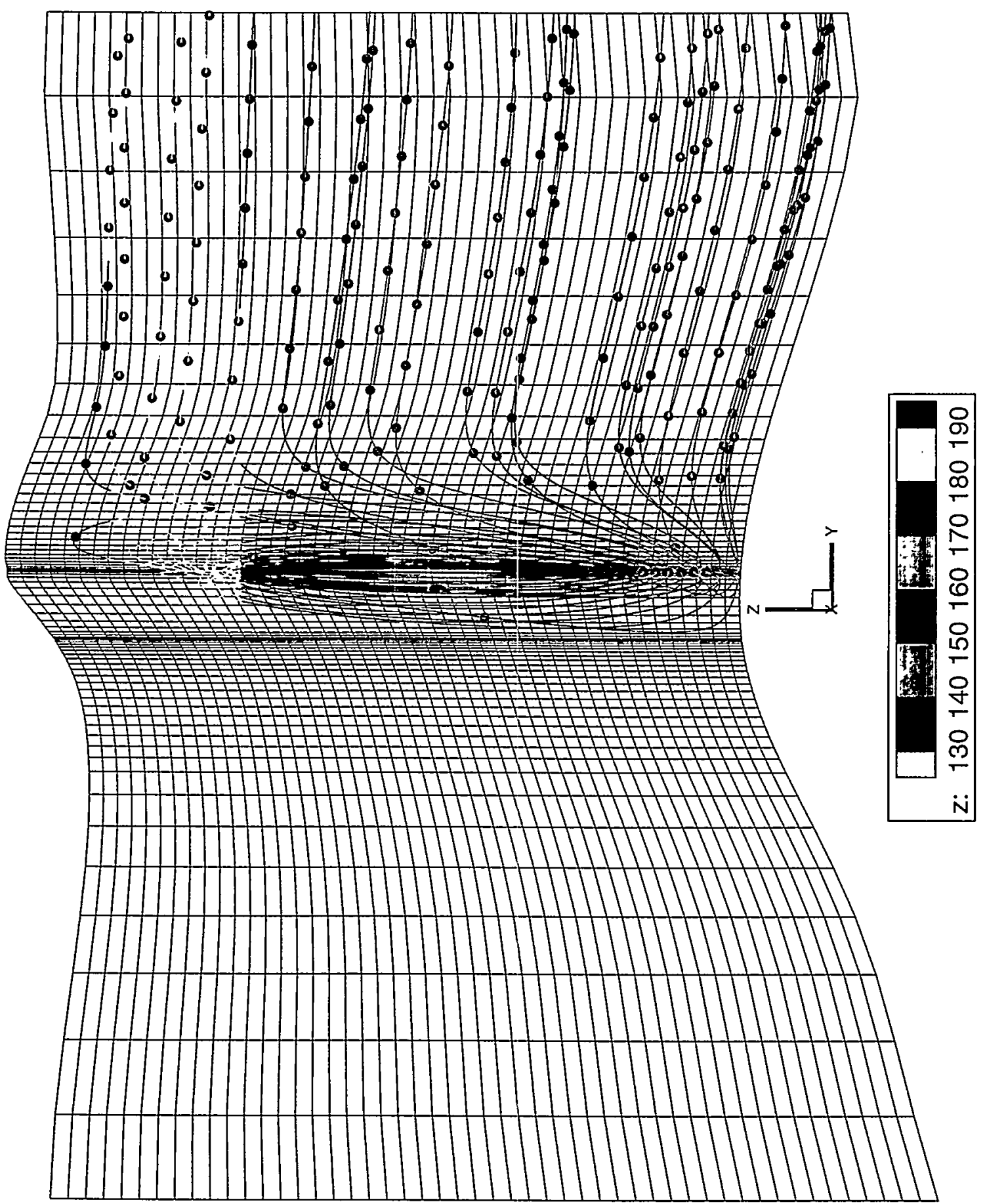

Figure 21. YZ Projection of Capture Zone for SSR-012 with 1-year Timing Markers (Nominal-A) 


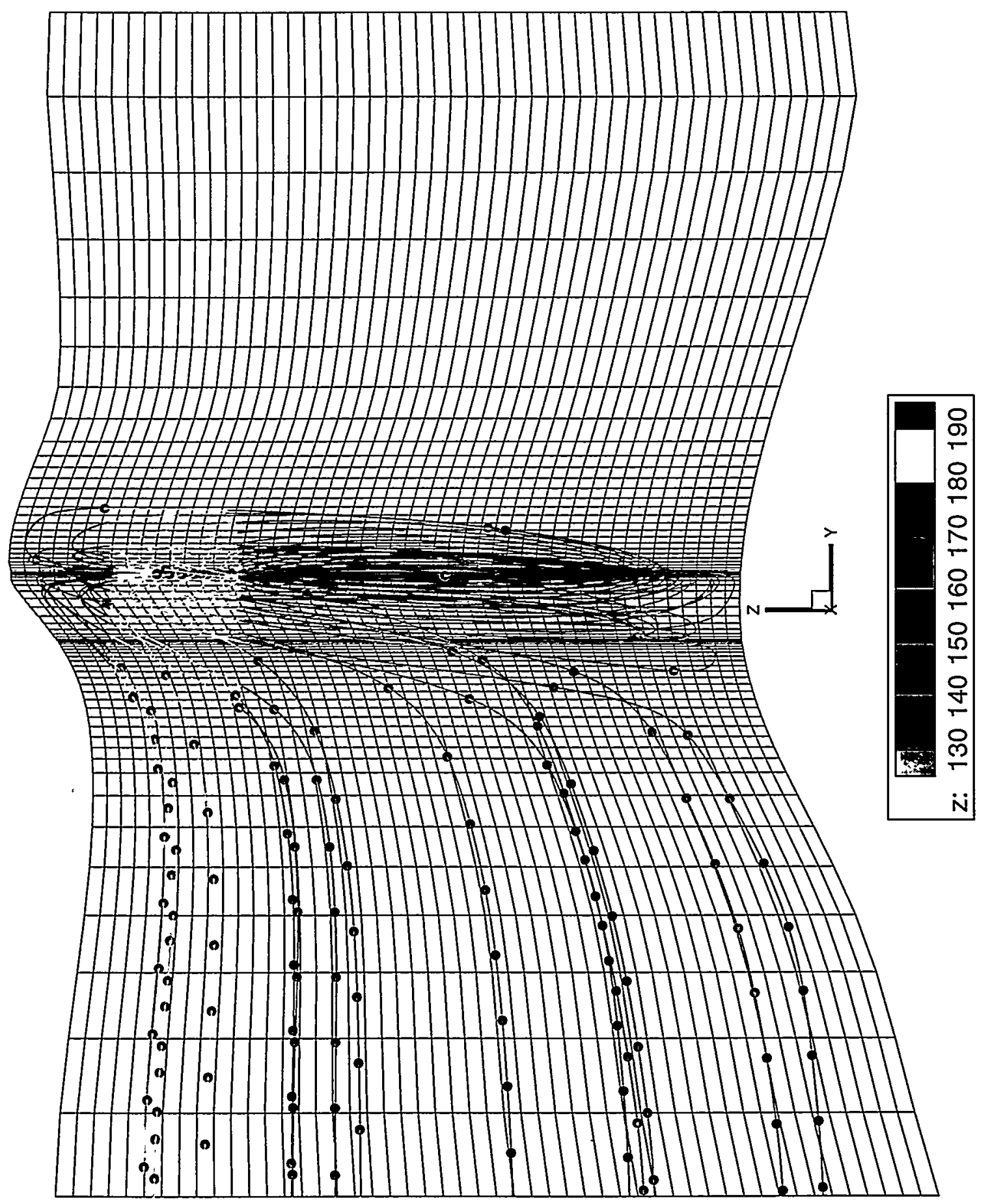

Figure 22. YZ Projection of Capture Zone for SSR-012 with 1-year Timing Markers (Nominal-A) 


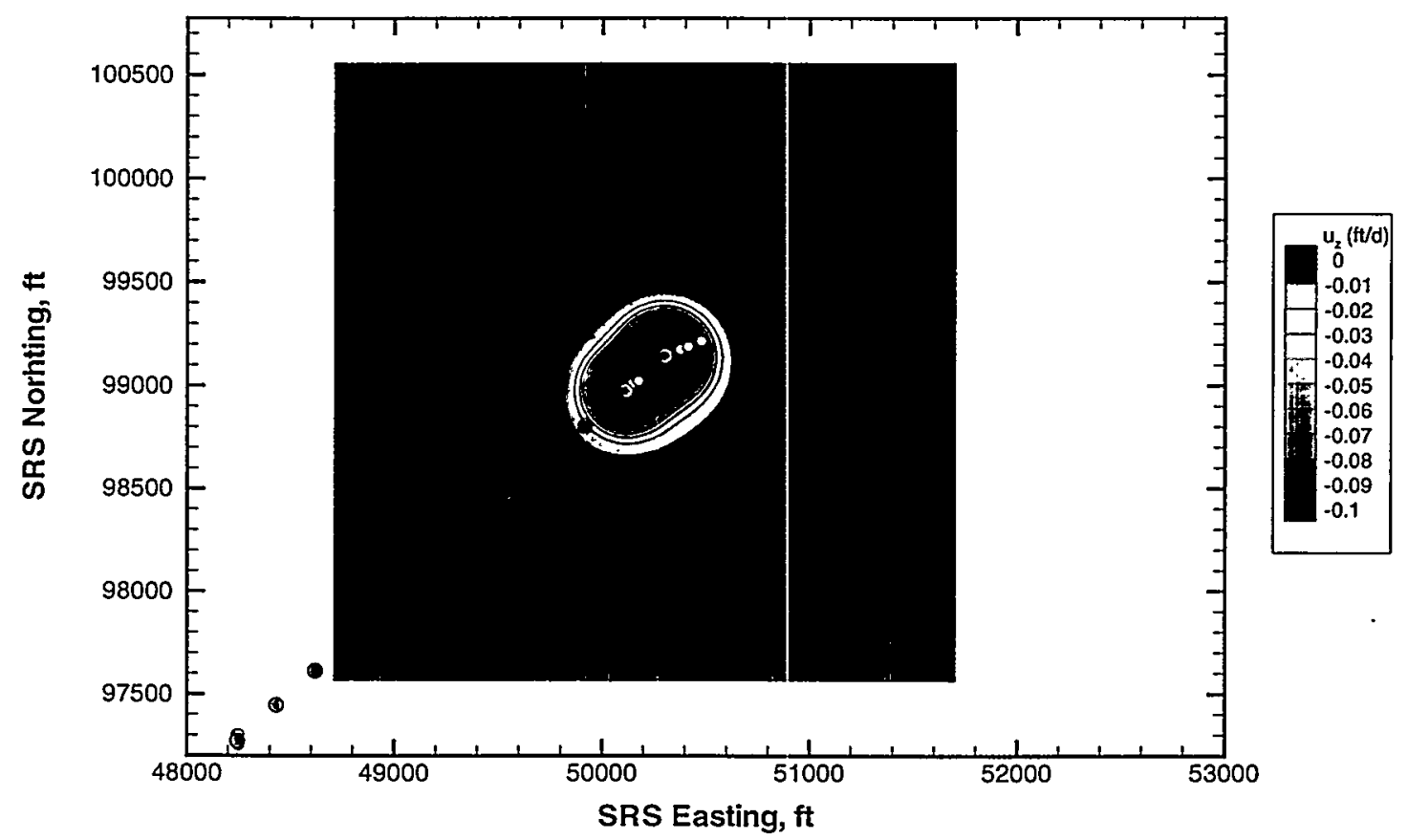

Figure 23. Contour Plot of Mid-plane Vertical Pore Velocity Field Between Wells (Nominal-A)

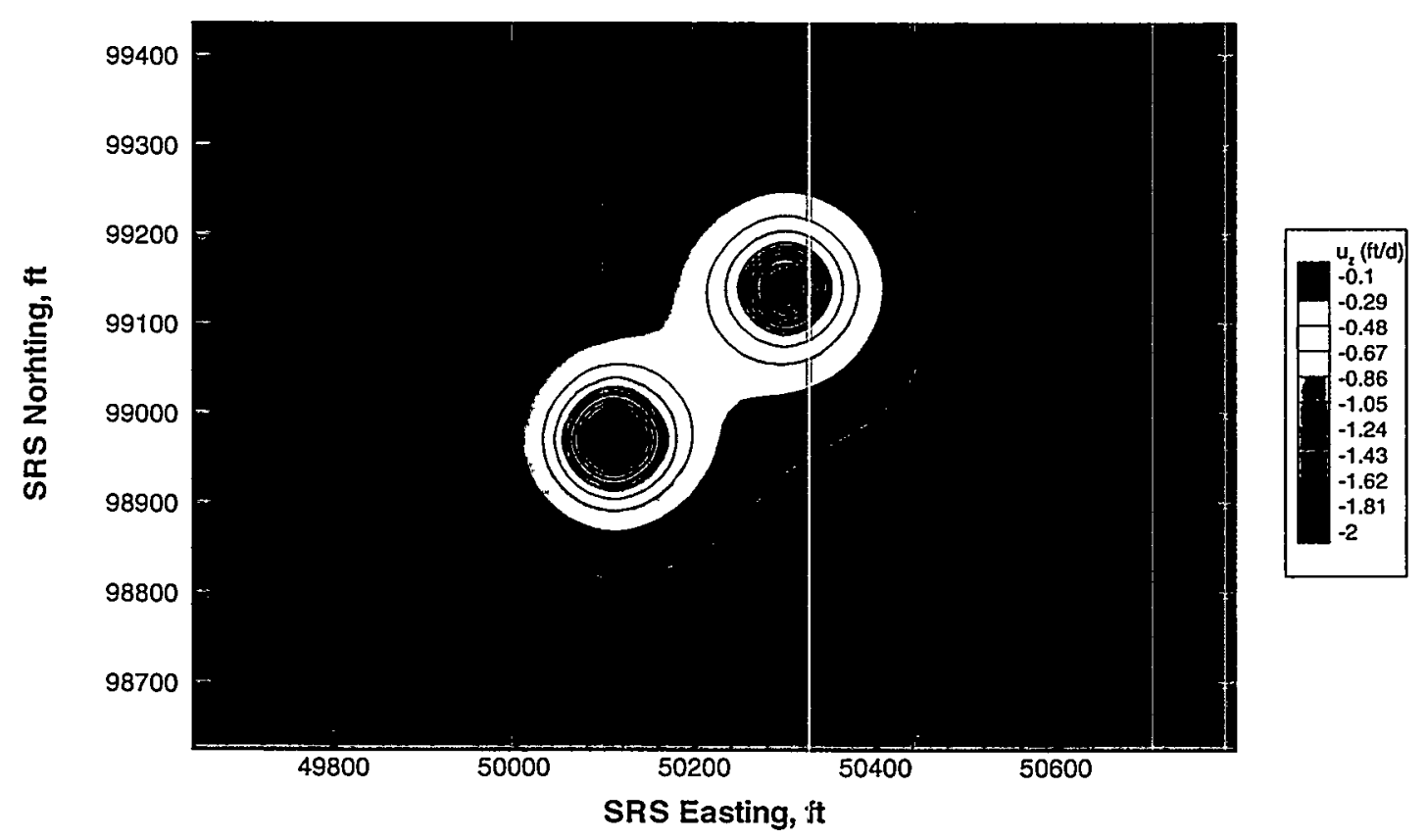

Figure 24. Closeup of Contour Plot of Mid-plane Vertical Pore Velocity Field Between Wells (Nominal-A) 


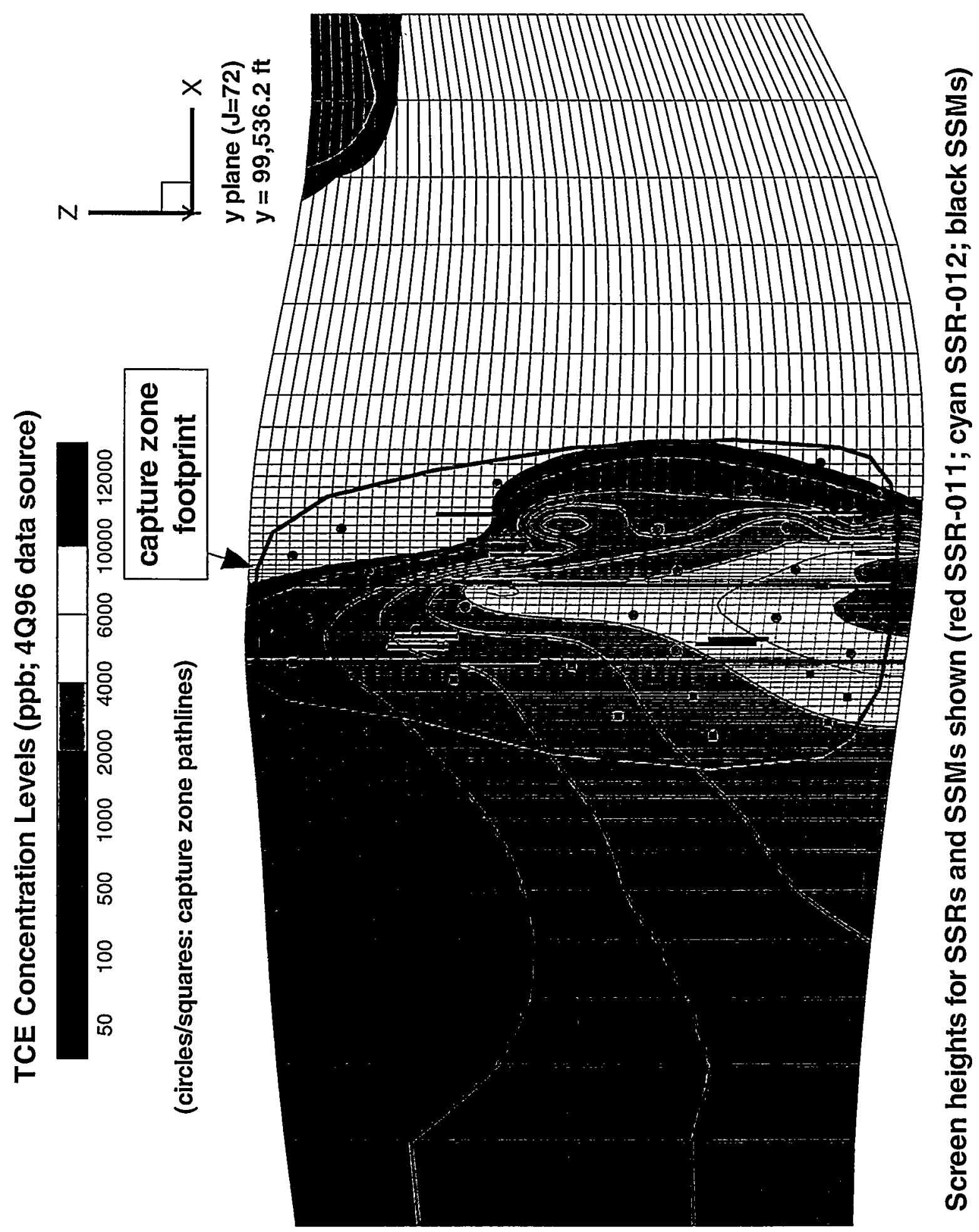

Figure 25. Inlet TCE Plume Profile to CSTR and Plug Flow Models 


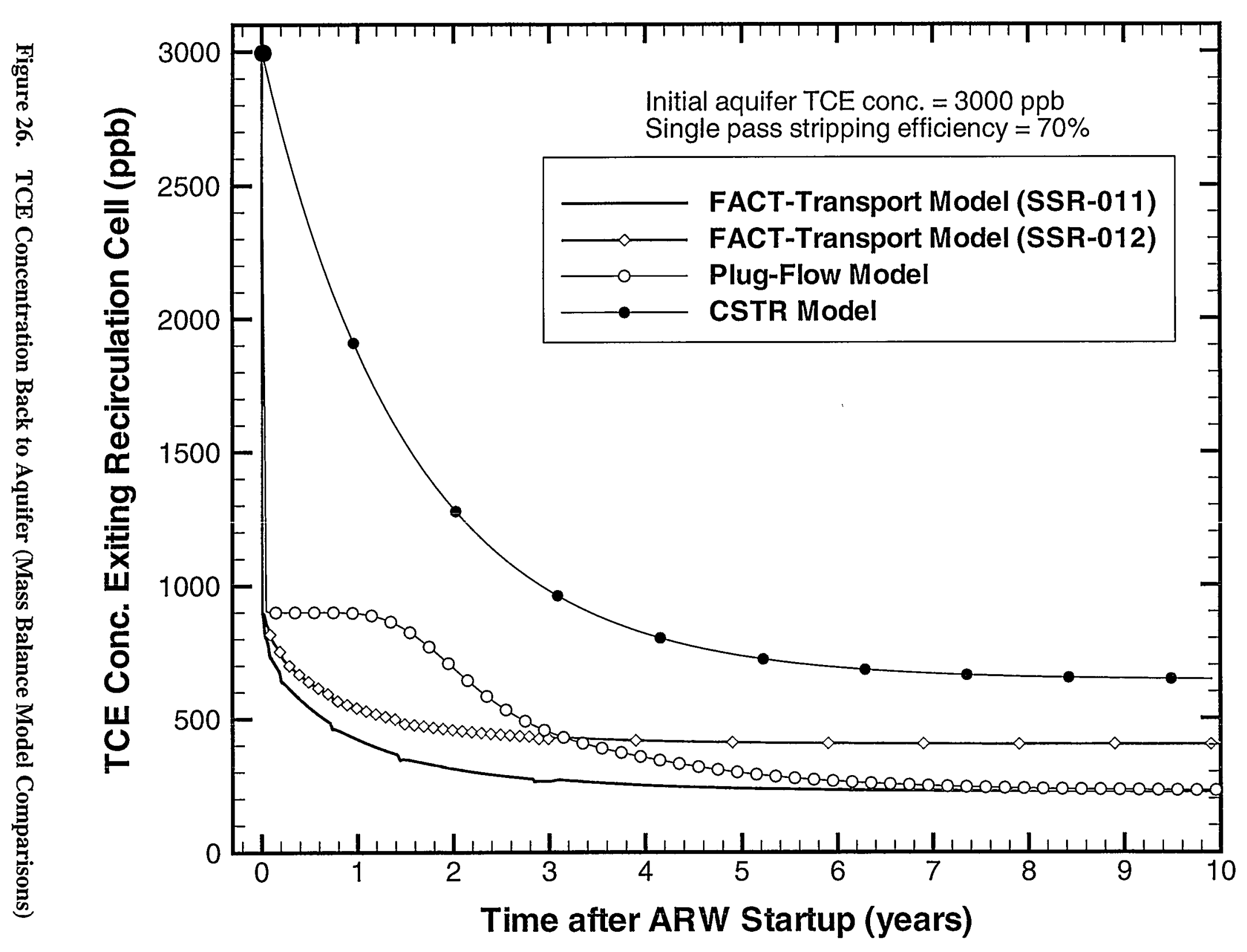




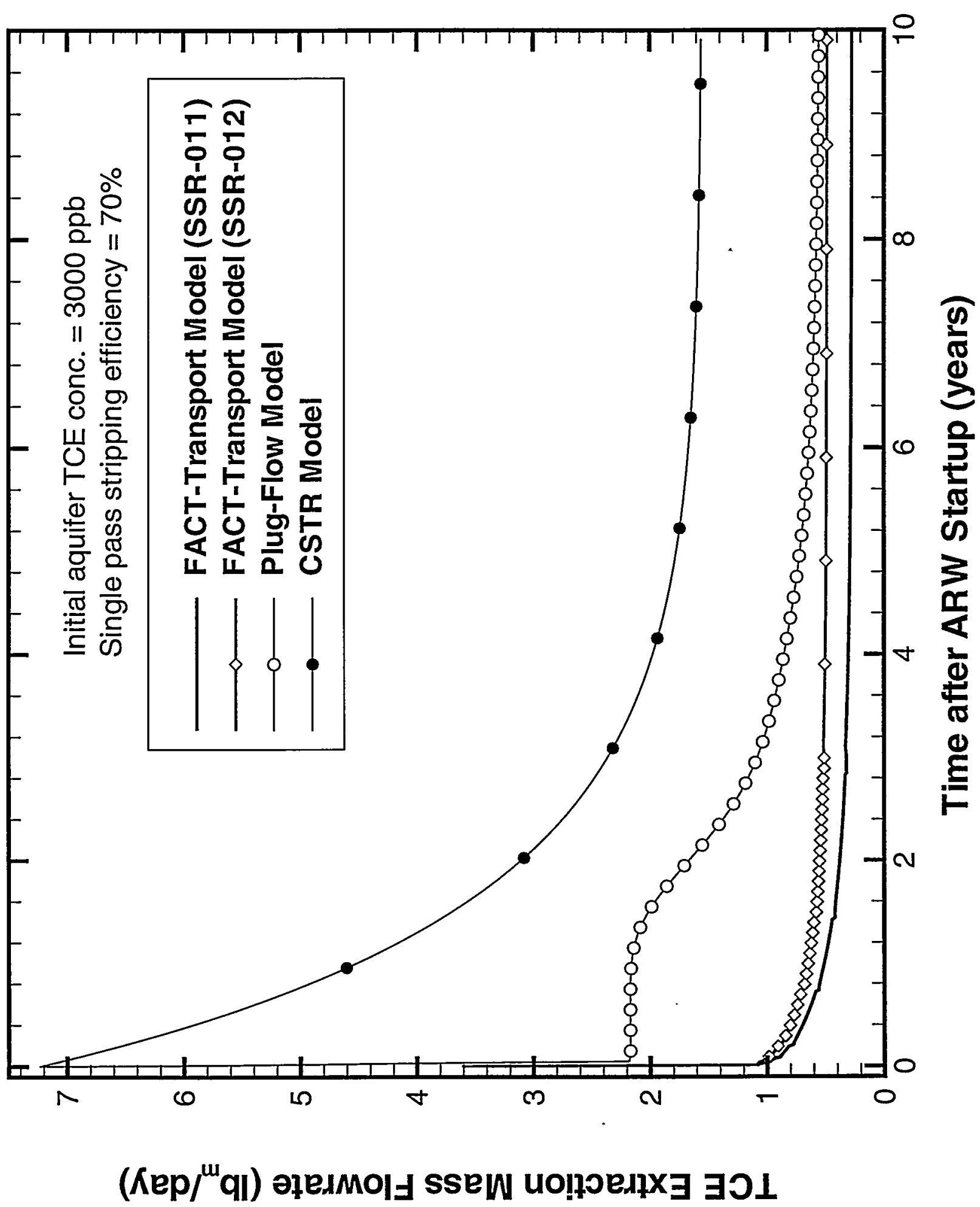

Figure 27. TCE Extraction Mass Flowrate $(\mathrm{Co}=3000 \mathrm{ppb}$, Nominal-A) 


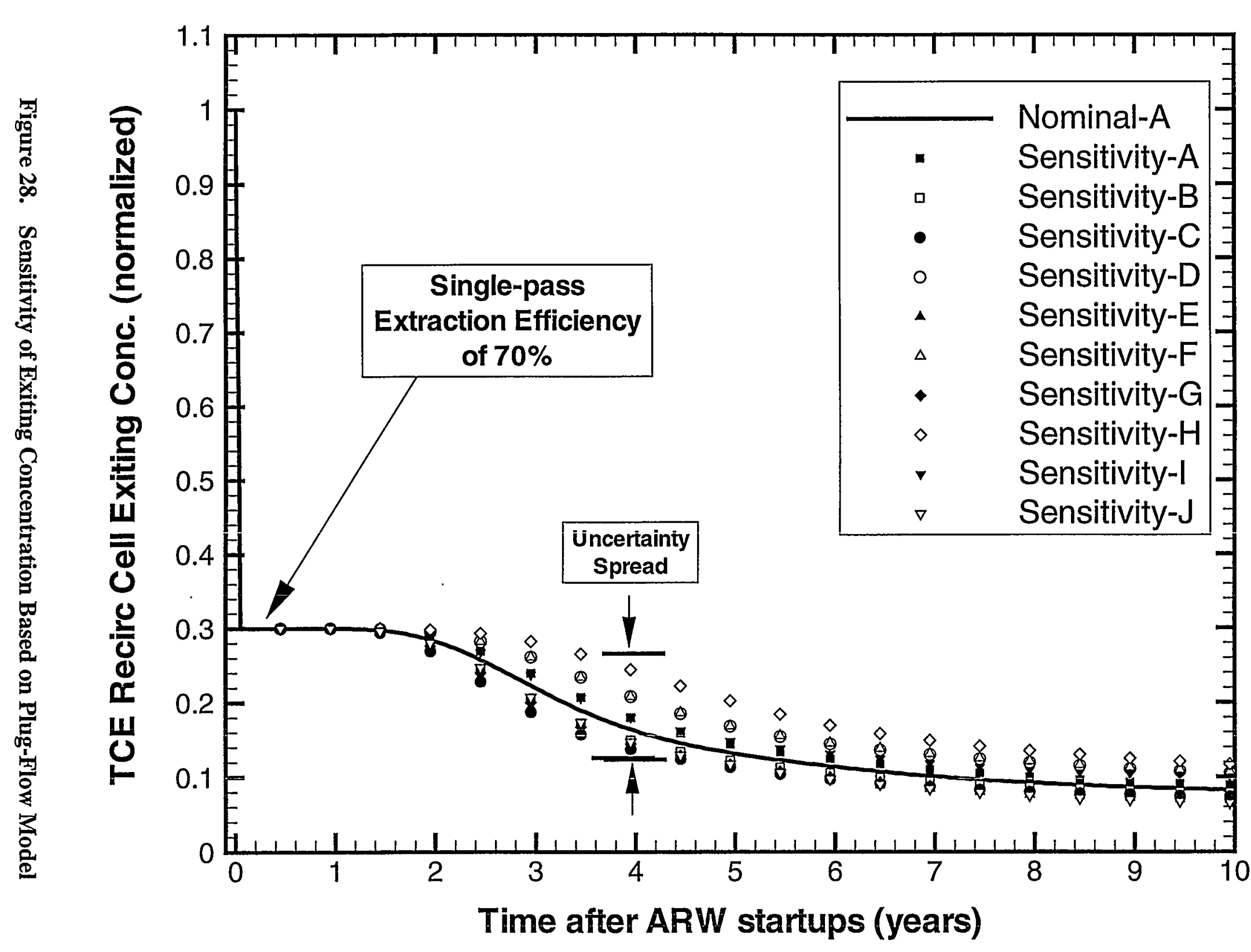




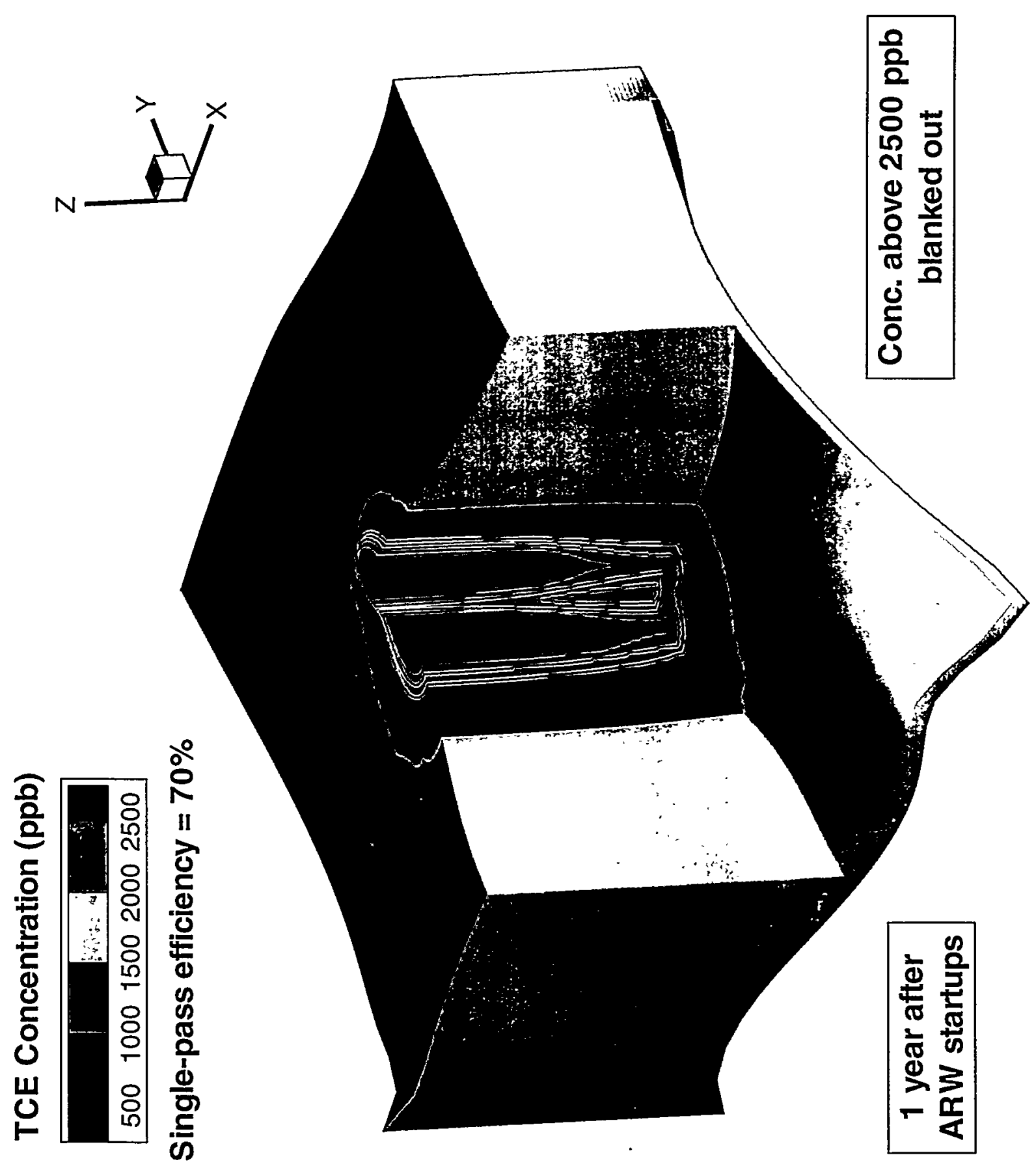

Figure 29. FACT Computed TCE Concentration Profile near SSR-011 and SSR-012 After 1 Year of ARW Operation (Nominal-A) 
Capture Zone Analyses of Two Airlift Recirculation Wells

Page:

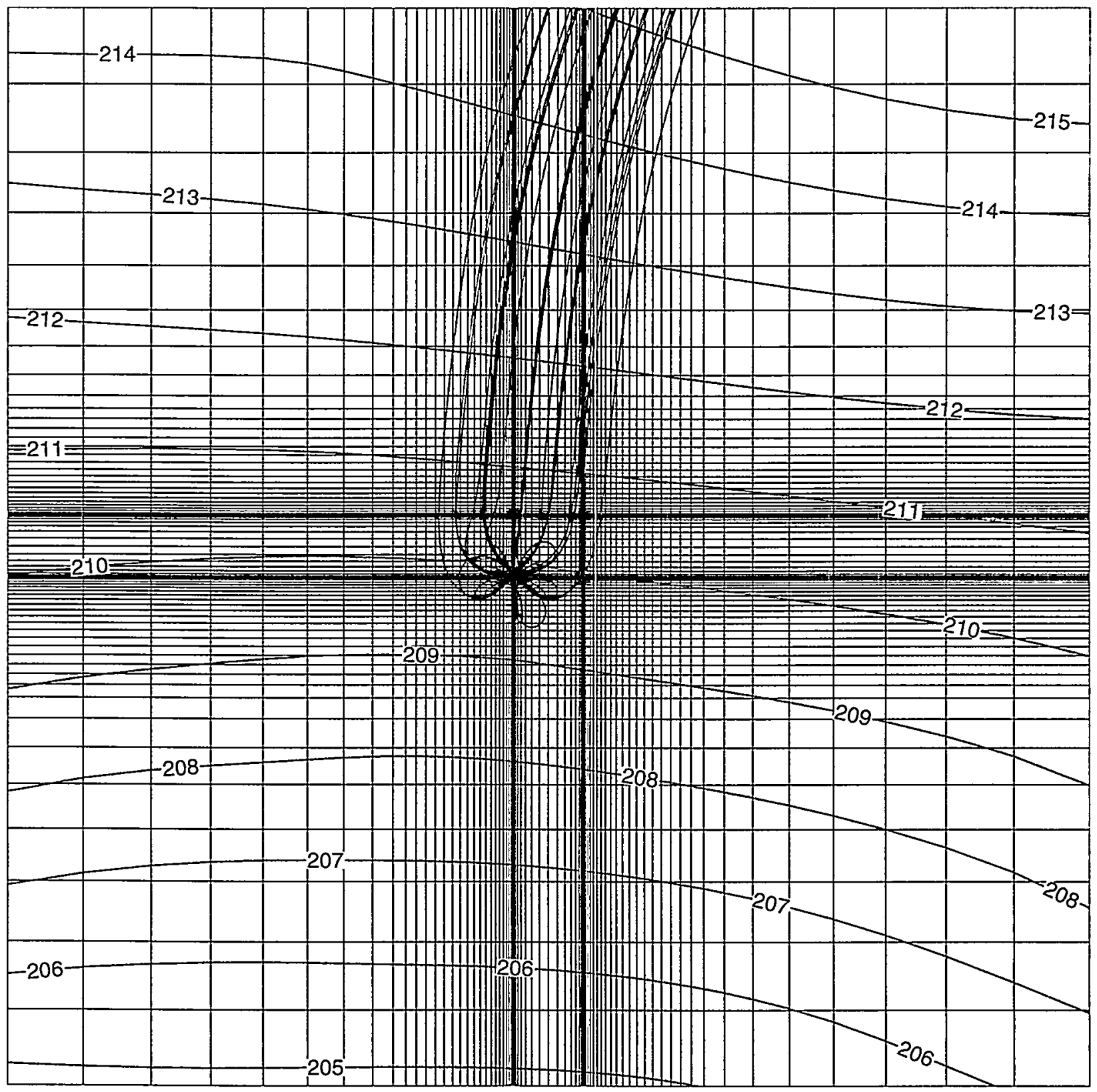

Figure 30. XY Projection of Capture Zone for SSR-011 (Nominal-B) 


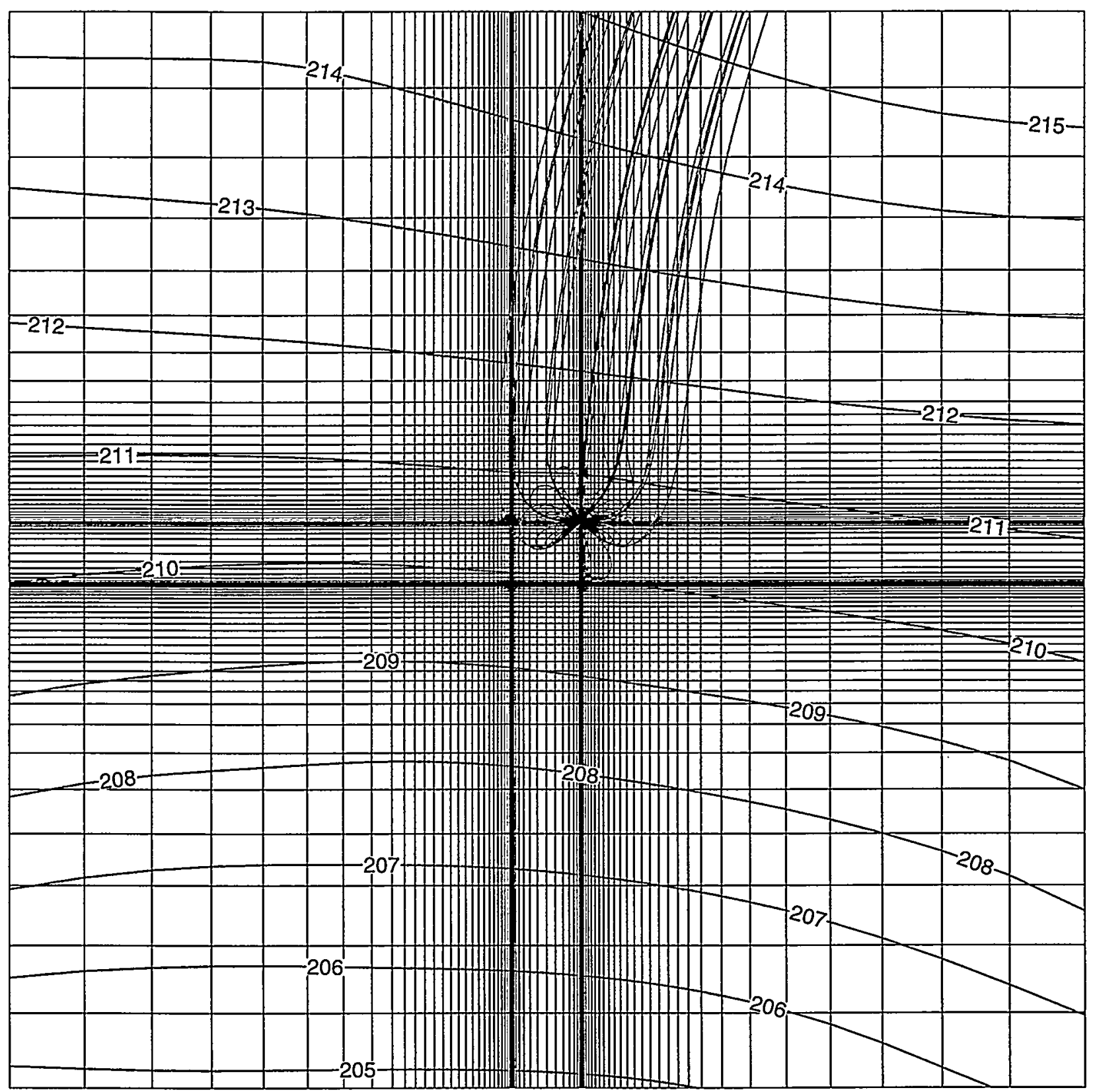

Figure 31. XY Projection of Capture Zone for SSR-012 (Nominal-C) 
Capture Zone Analyses of Two Airlift Recirculation Wells Revision:

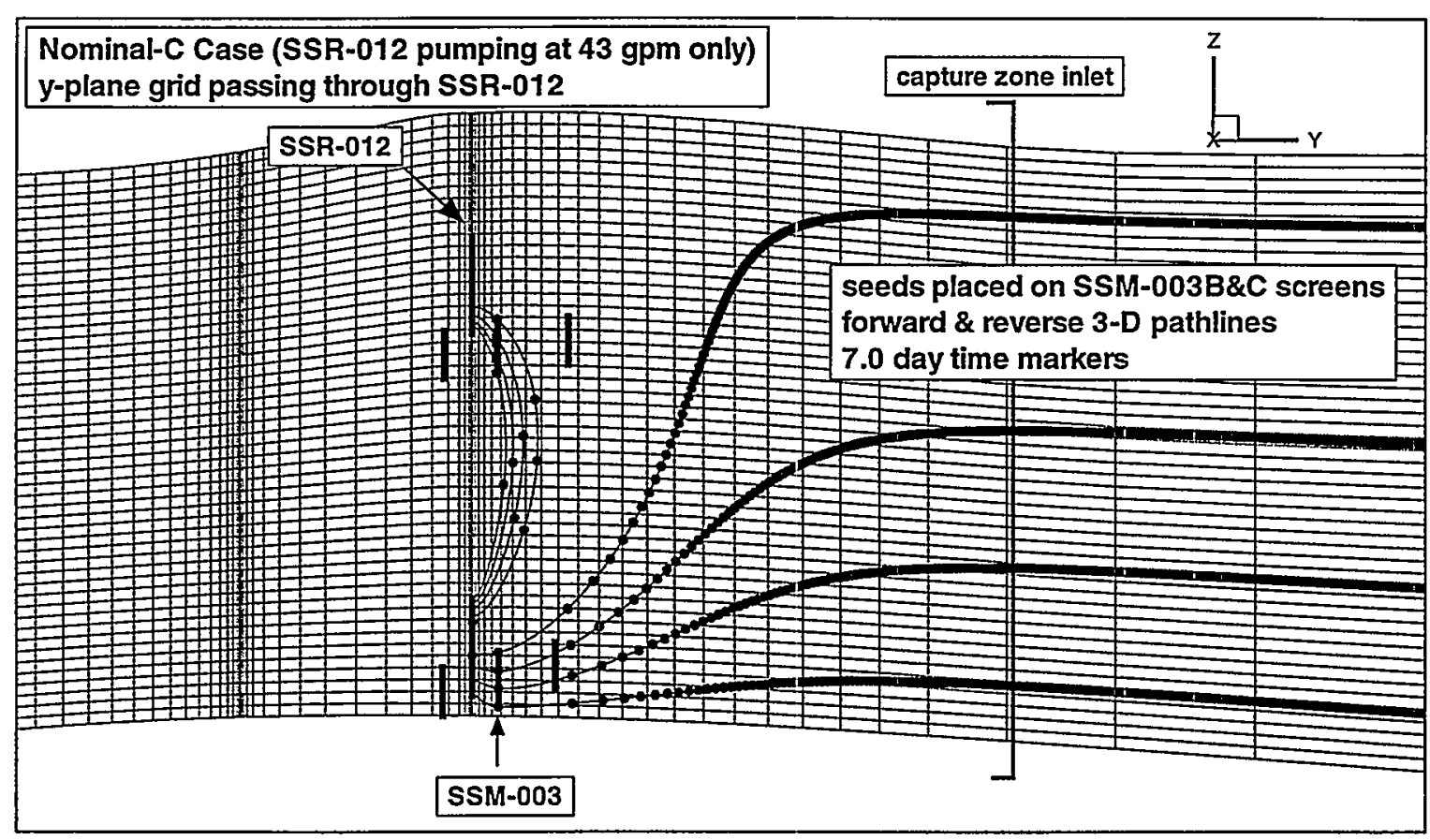

Figure 32. Vertical View of 3-D Pathlines Passing Through Monitoring Well SSM-003

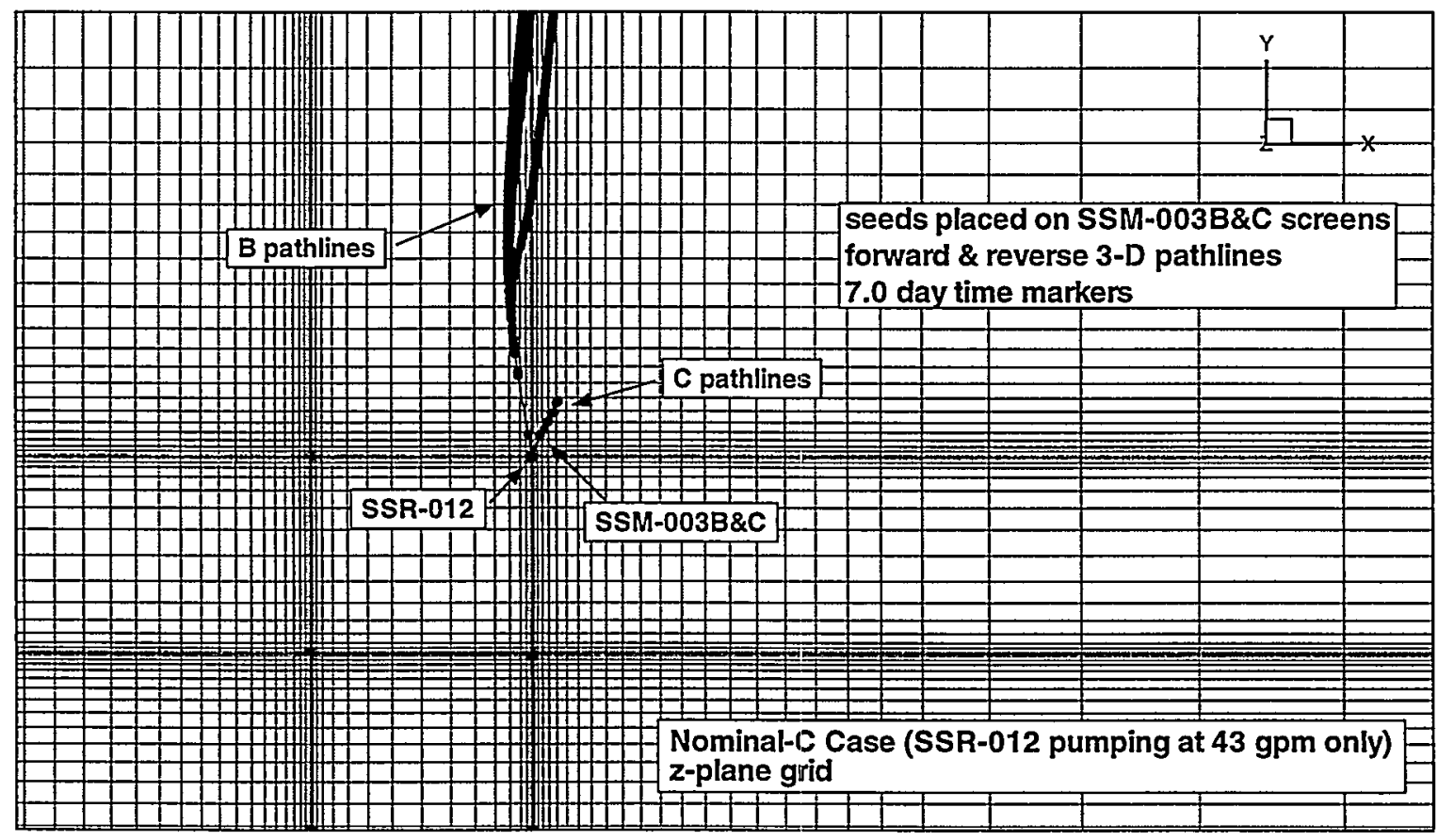

Figure 33. Plan View of 3-D Pathlines Passing Through Monitoring Well SSM-003 
Capture Zone Analyses of Two Airlift Recirculation Wells

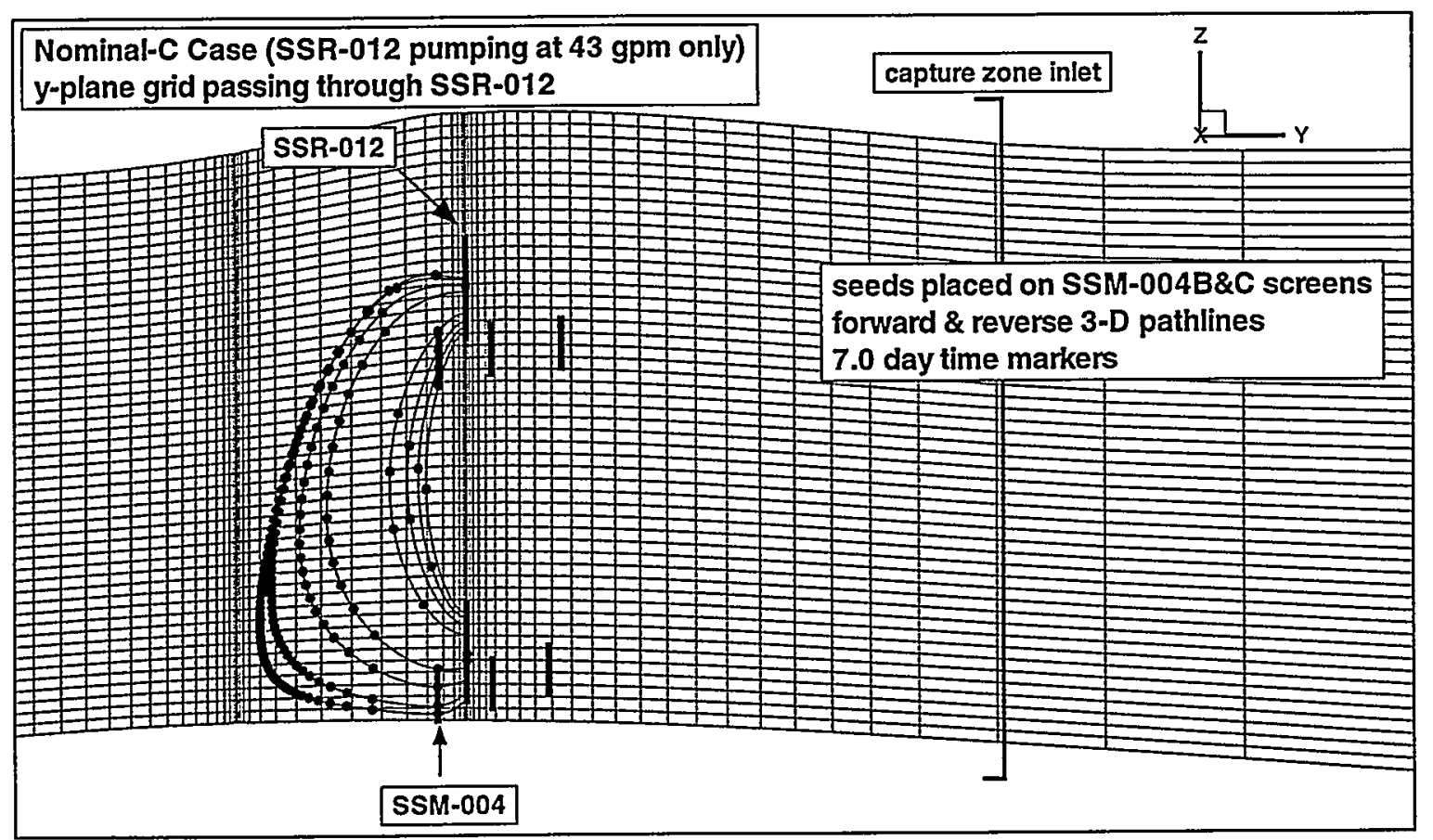

Figure 34. Vertical View of 3-D Pathlines Passing Through Monitoring Well SSM-004

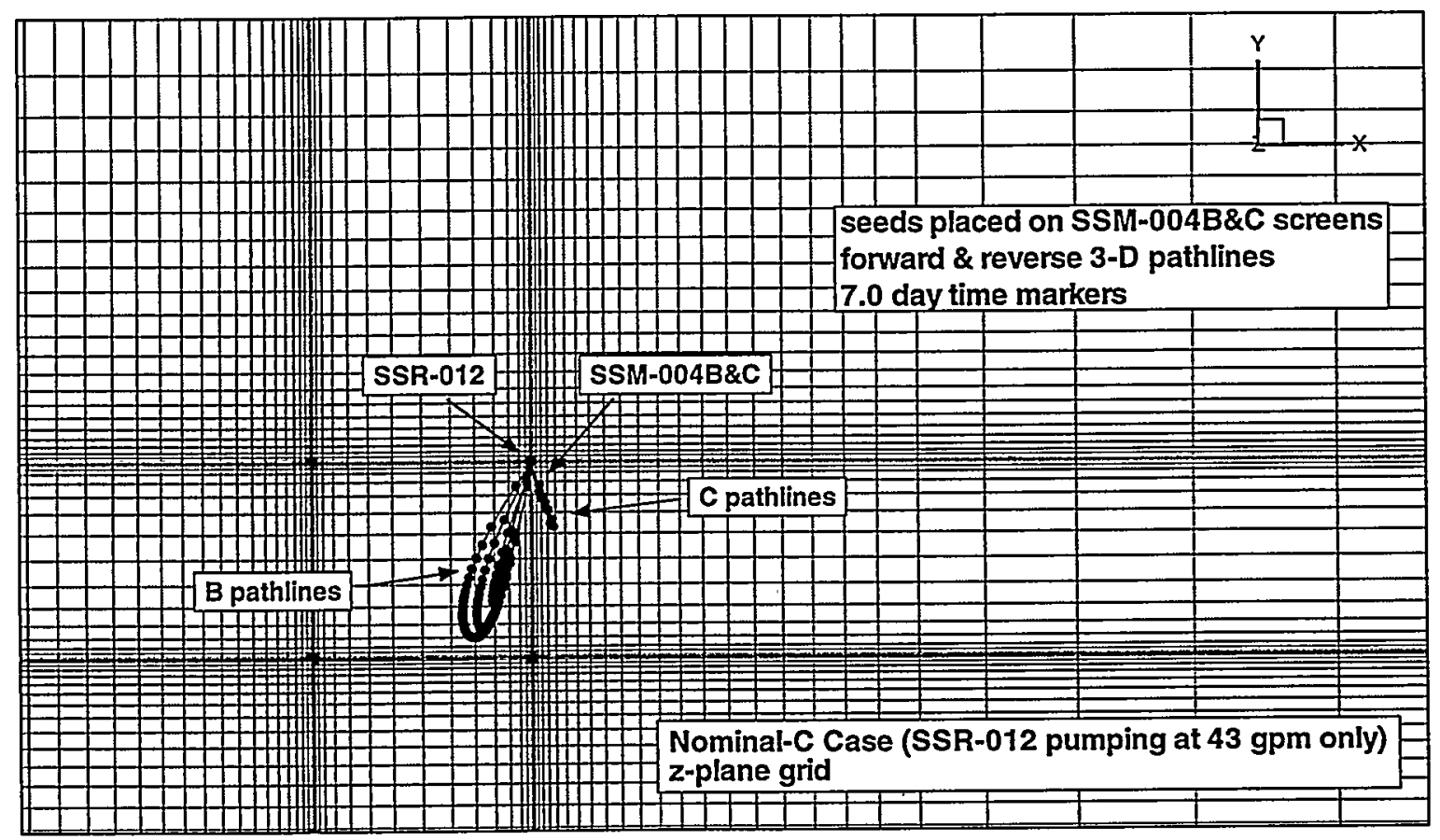

Figure 35. Plan View of 3-D Pathlines Passing Through Monitoring Well SSM-004 


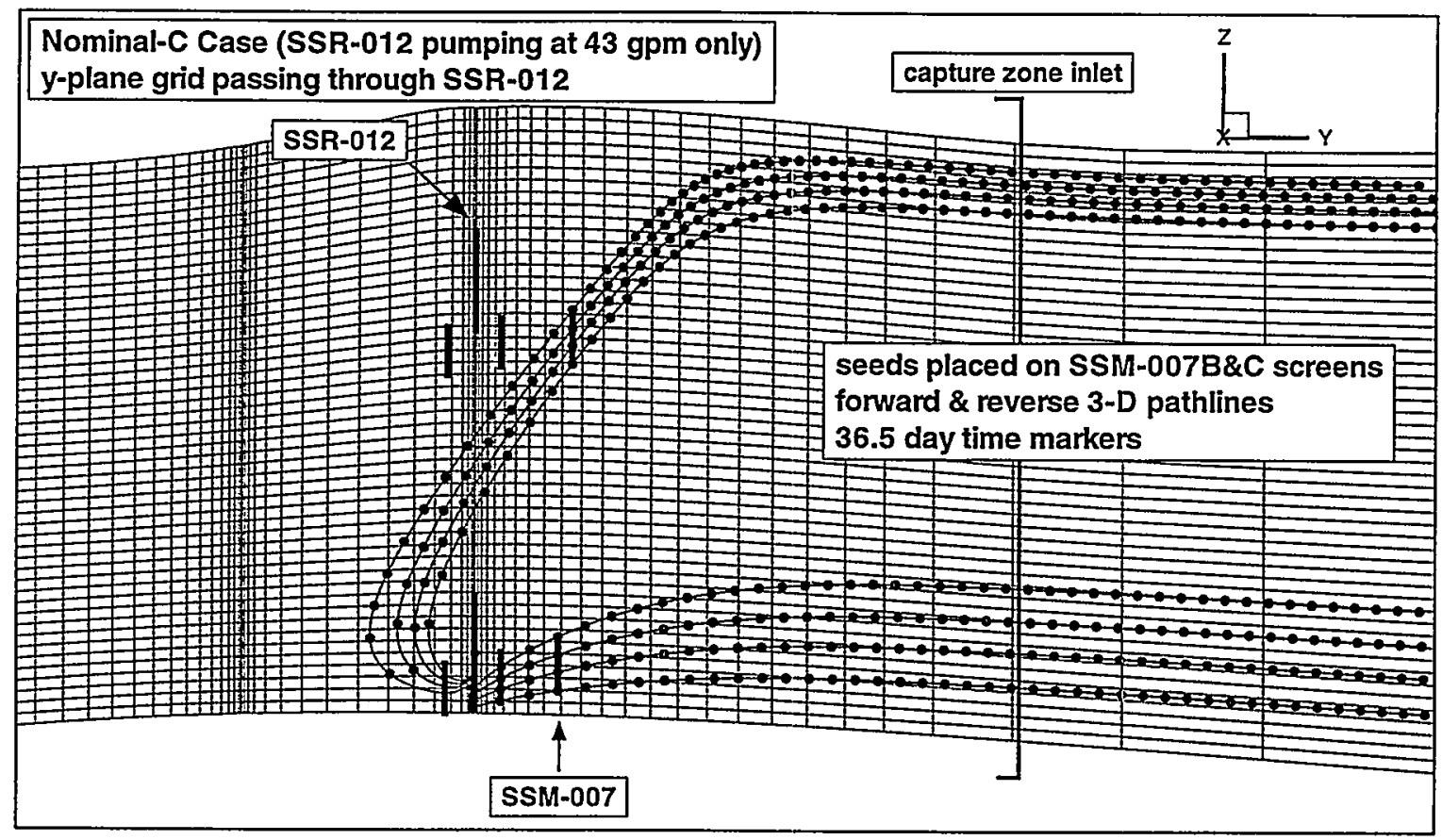

Figure 36. Vertical View of 3-D Pathlines Passing Through Monitoring Well SSM-007

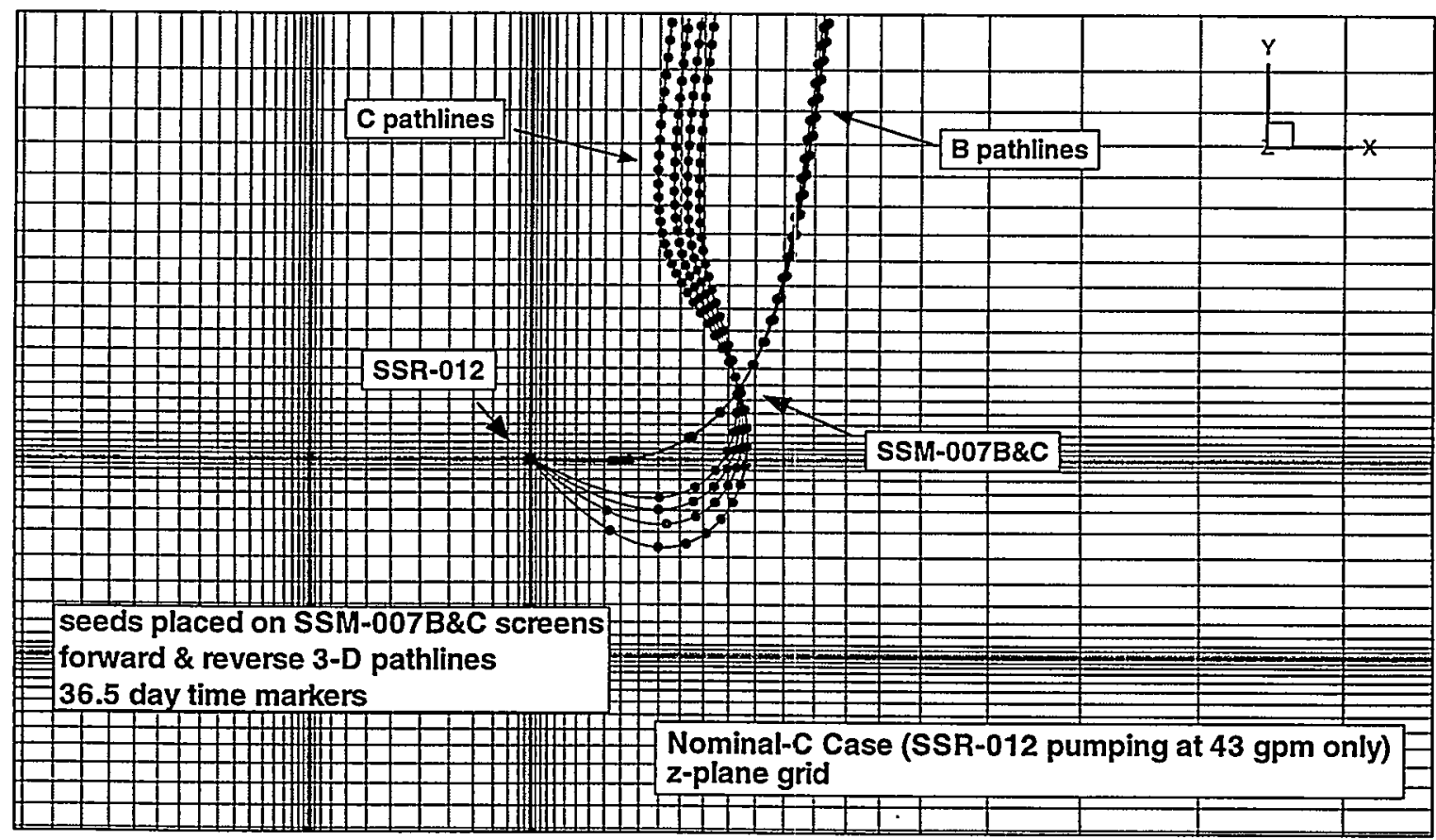

Figure 37. Plan View of 3-D Pathlines Passing Through Monitoring Well SSM-007 